Prepared in cooperation with the East Bay Municipal Utility District

\title{
Lithostratigraphic, Borehole-Geophysical, Hydrogeologic, and Hydrochemical Data from the East Bay Plain, Alameda County, California
}

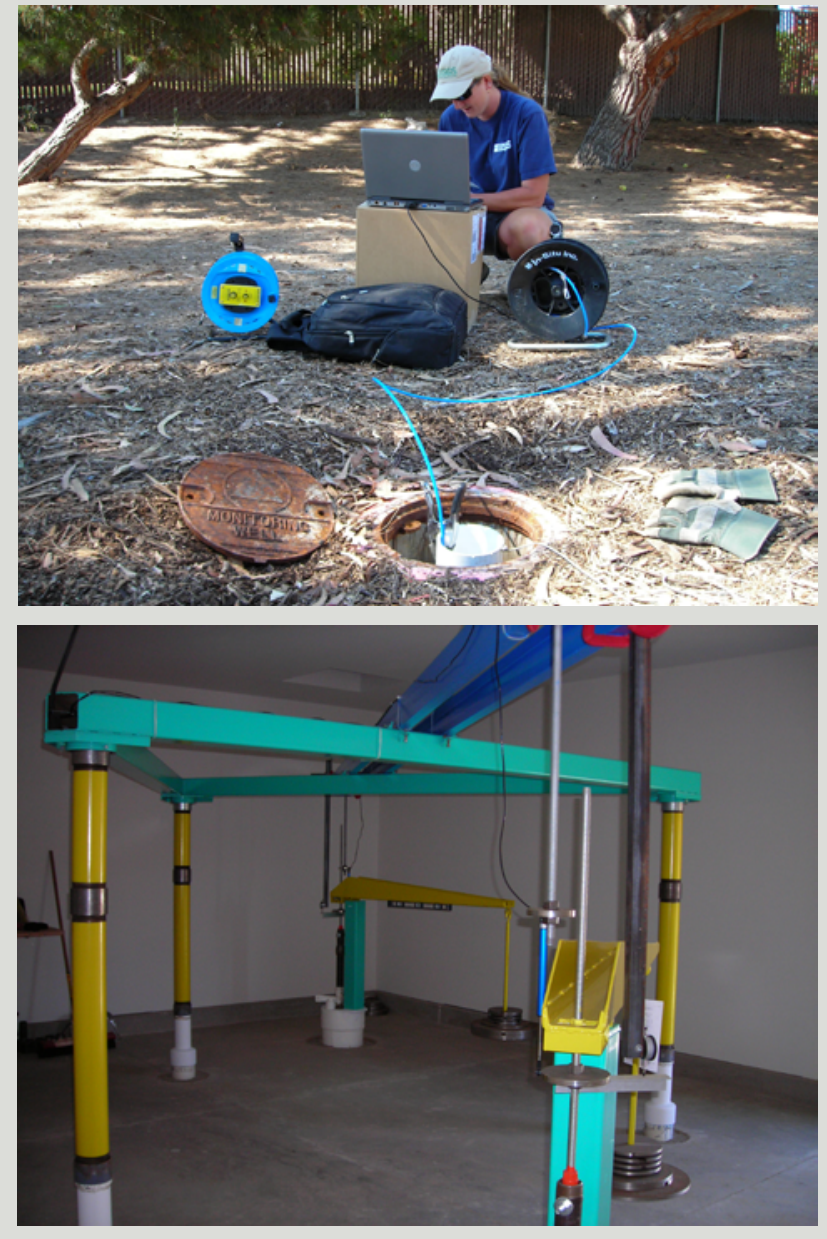

Data Series 890

U.S. Department of the Interior U.S. Geological Survey

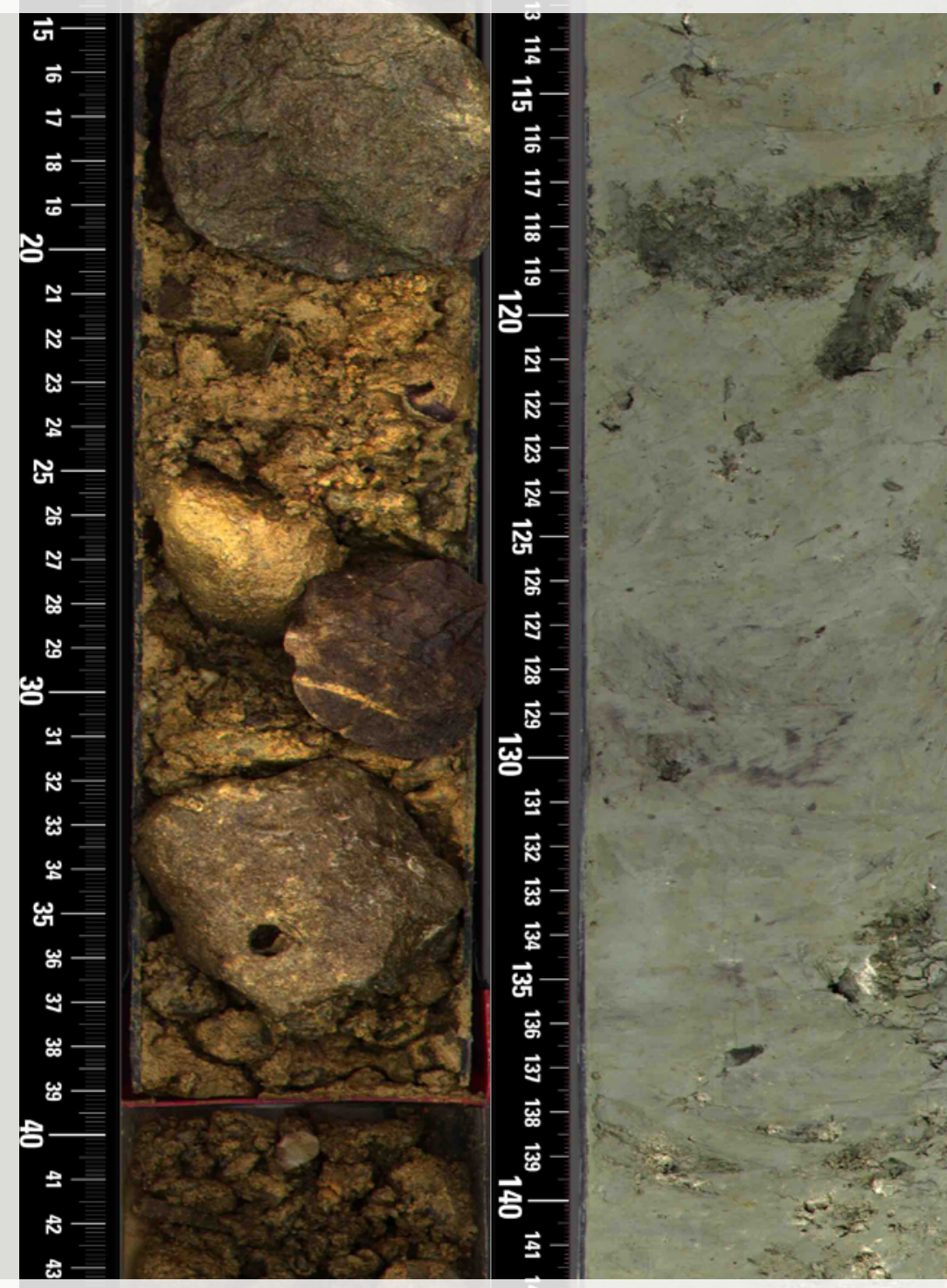




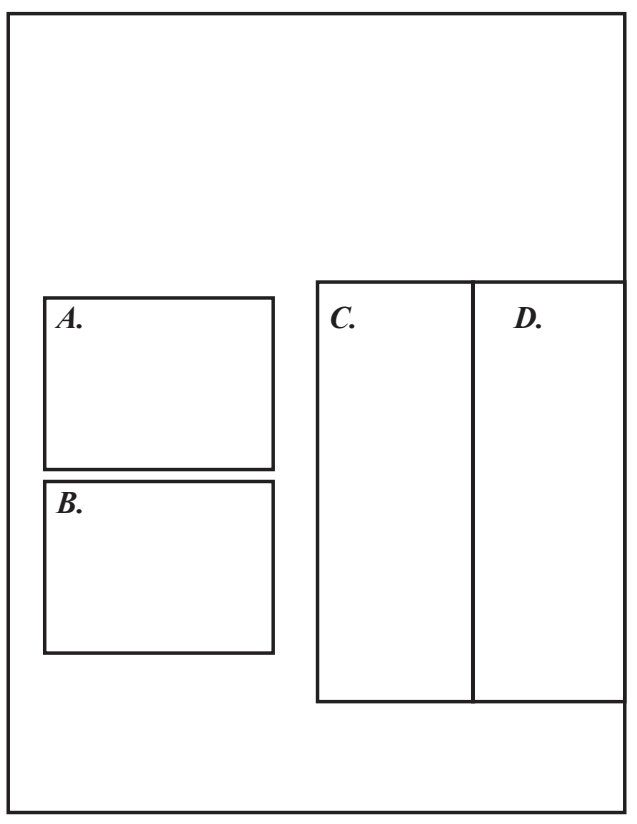

Front cover.
A. U.S. Geological Survey hydrologist analyzing slug-test data (Rhett Everett, U.S. Geological Survey)
B. Dual stage extensometer (Michelle Sneed, U.S. Geological Survey)
C. Portion of core EBAY_45 showing predominantly coarse-grained sediment (U.S. Geological Survey)
D. Portion of core EBAY_23 showing predominantly fine-grained sediment (U.S. Geological Survey)

\section{Back cover}

Two U.S. Geological Survey Research Drilling Program drill rigs operating simultaneously (Michelle Sneed, U.S. Geological Survey) 


\section{Lithostratigraphic, Borehole-Geophysical, Hydrogeologic, and Hydrochemical Data from the East Bay Plain, Alameda County, California}

By Michelle Sneed, Patricia v.P. Orlando, James W. Borchers, Rhett Everett, Mike Solt, Mary McGann, Heather Lowers, and Shannon Mahan

Prepared in cooperation with the East Bay Municipal Utility District

Data Series 890 


\title{
U.S. Department of the Interior SALLY JEWELL, Secretary
}

\section{U.S. Geological Survey Suzette M. Kimball, Acting Director}

\author{
U.S. Geological Survey, Reston, Virginia: 2015
}

For more information on the USGS - the Federal source for science about the Earth, its natural and living resources, natural hazards, and the environment, visit http://www.usgs.gov or call 1-888-ASK-USGS.

For an overview of USGS information products, including maps, imagery, and publications, visit http://www.usgs.gov/pubprod

To order this and other USGS information products, visit http://store.usgs.gov

Any use of trade, firm, or product names is for descriptive purposes only and does not imply endorsement by the U.S. Government.

Although this information product, for the most part, is in the public domain, it also may contain copyrighted materials as noted in the text. Permission to reproduce copyrighted items must be secured from the copyright owner.

Suggested citation:

Sneed, Michelle, Orlando, P.v.P., Borchers, J.W., Everett, Rhett, Solt, Mike, McGann, Mary, Lowers, Heather, and Mahan, Shannon, 2015, Lithostratigraphic, borehole-geophysical, hydrogeologic, and hydrochemical data from the East Bay Plain, Alameda County, California: U.S. Geological Survey Data Series 890, 56 p., http://dx.doi.org/10.3133/ ds890.

ISSN 2327-638X 


\section{Contents}

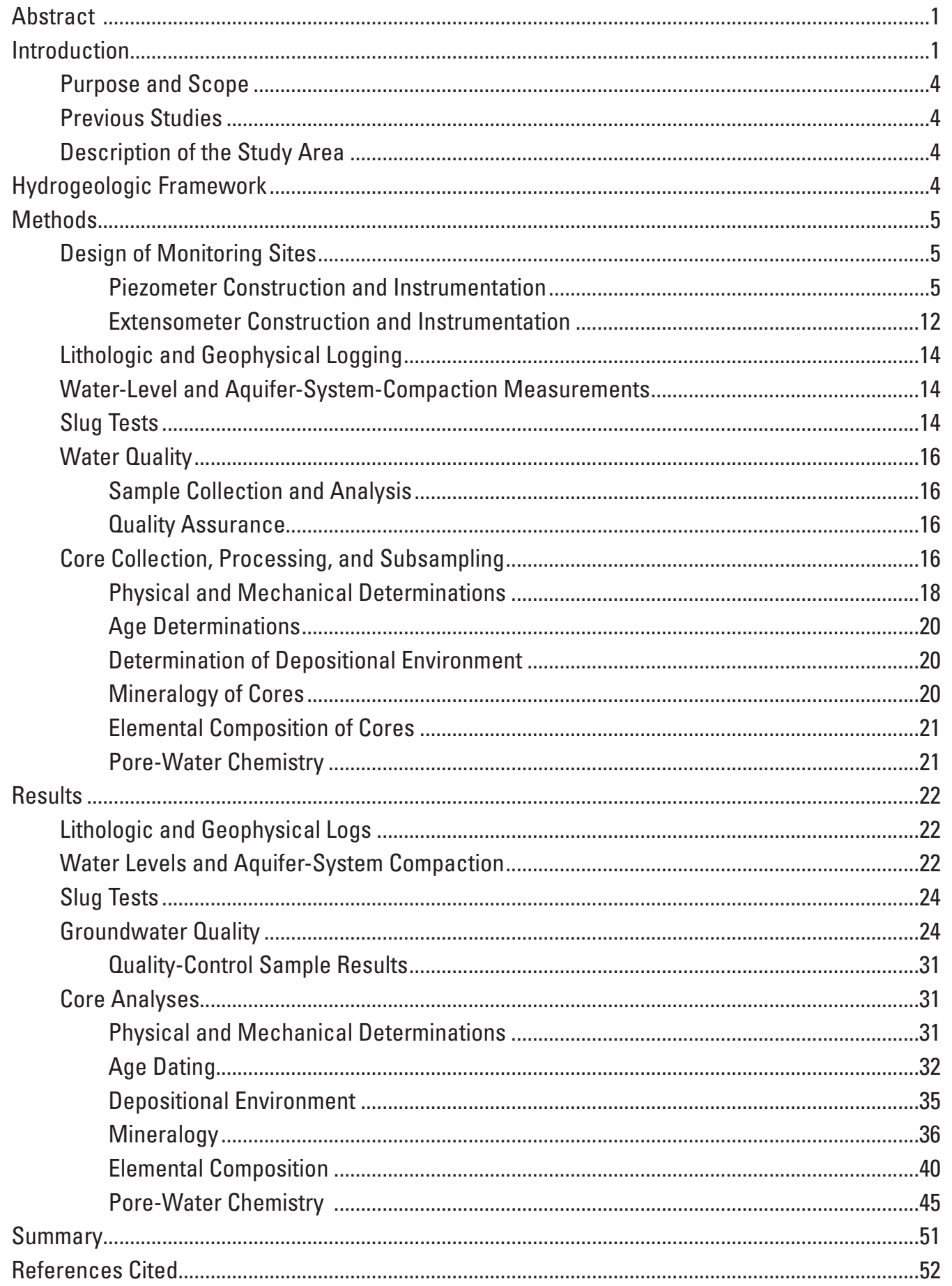




\section{Figures}

1. Map showing the piezometer, extensometer, and slug-test locations, East Bay Plain, Alameda County, California..

2. Graphs showing well construction and lithological, geophysical, and velocity logs for East Bay monitoring sites: $A$, Bayside; $B$, East Bay Extensometer-1 Monitoring Site at Bayside; $C$, East Bay Extensometer-2 Monitoring Site at Bayside; $D$, East Bay Municipal Utility District Yard; E, Kipp Academy; and F, Stenzel Park.

3. Diagram showing the construction of the dual-stage extensometer at Bayside .............13

4. Graphs showing $A$, Periodic and continuous water levels in East Bay Bayside Monitoring site piezometers, including nearby tide cycles. B, Aquifer-system compaction measurements in Bayside extensometers, grey areas indicated periods of friction. C, Surface barometric pressure and shelter temperature for Bayside extensometers.

5. Graph showing comparison of isotopic ratios of hydrogen and oxygen between pore-water and groundwater at similar depths from the East Bay Bayside Monitoring Site (EBAY) core and EBAY piezometers, respectively...

6. Graph showing relative clay abundance versus depth of core samples from East

Bay Bayside monitoring site in San Lorenzo, California

7. Example of elements, scandium, zinc, and iron, in core samples from the East Bay Bayside Monitoring Site borehole, showing similar patterns in concentration at depth below land surface in feet

8. Graph showing comparison of the water-quality indicators $\mathrm{pH}$ and alkalinity between pore water and groundwater from the East Bay Bayside Monitoring Site (EBAY) core and EBAY piezometers, respectively

9. Graphs showing comparison of selected major-ion concentrations between pore water and groundwater from the East Bay Bayside Monitoring Site (EBAY) core and EBAY piezometers, respectively.....

10. Graphs showing comparison of selected trace-metal concentrations between pore water and groundwater from the East Bay Bayside Monitoring Site (EBAY) core and EBAY piezometers, respectively...

\section{Tables}

1. Summary of sites, boreholes, piezometers, and types of data collected for the Bayside Groundwater Project with table and figure references .

2. Well-identification and construction information for slug test and water-quality data collection sites, Alameda County, California

3. Core recovery for each 5-foot interval from the East Bay Bayside Monitoring Site and East Bay Extensometer-2 Monitoring Site (EXT2) boreholes

4. Summary of analyses conducted on sediment cores from the East Bay Bayside Monitoring Site (EBAY) and East Bay Extensometer-2 Monitoring Site (EXT2) boreholes.

5. Results of slug tests from monitoring wells, Alameda County, California...

6. Water-quality indicators in groundwater samples collected in June 2007 and in December 2008.

7. Nutrients in groundwater samples collected in June 2007 and analyzed by the U.S. Geological Survey National Water Quality Laboratory, Denver, Colorado . 


\section{Tables-Continued}

8. Major and minor ions, and total dissolved solids detected in filtered groundwater samples collected in June 2007 and in December 2008 and analyzed by the U.S. Geological Survey National Water Quality Laboratory, Denver, Colorado ...............28

9. Trace metals in groundwater samples collected in June 2007 and in December 2008 and analyzed by the U.S. Geological Survey National Water Quality Laboratory,

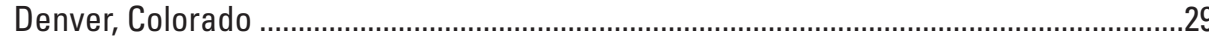

10. Stable isotope ratios, tritium, and carbon-14 activities in groundwater ...........................30

11. Moisture content by mass and percent for core samples from the East Bay Bayside Monitoring Site borehole...

12. Vertical hydraulic conductivity of selected cores from the East Bay Bayside Monitoring Site and East Bay Extensometer-2 Monitoring Site boreholes.

13. Physical properties of selected cores from the East Bay Bayside Monitoring Site and East Bay Extensometer-2 Monitoring Site boreholes.

14. Consolidation test results of selected cores from the East Bay Bayside Monitoring Site borehole...

15. Quartz blue-light optically stimulated luminescence (OSL) and feldspar infrared stimulated luminescence ages of selected cores from the East Bay Bayside Monitoring Site and East Bay Extensometer-2 Monitoring Site boreholes

16. Percentage abundance of the benthic foraminifera in core from the East Bay Bayside Monitoring Site borehole

17. Relative abundance of minerals determined from $x$-ray defraction analyses of core samples collected from the EBAY borehole, San Lorenzo, California .

18. Scanning electron microscopy/energy dispersive spectroscopy (SEM/EDS) results showing the presence or absence of minerals from core samples collected from the East Bay Bayside Monitoring Site (EBAY) borehole, San Lorenzo, California.

19. Comparison between minerals detected by scanning electron microscope (SEM) and X-ray diffraction (XRD) from core samples collected from the East Bay Bayside Monitoring Site (EBAY) borehole, San Lorenzo, California ...

20. Comparison between relative grain sizes detected by scanning electron microscope (SEM) and X-ray diffraction (XRD) analyses of core samples collected from the East Bay Bayside Monitoring Site (EBAY) borehole, San Lorenzo, California.

21. Element concentrations determined by inductively coupled plasma-mass spectroscopy (ICP-MS) analyses of core samples collected from the East Bay Bayside Monitoring Site borehole, San Lorenzo, California.

22. Element concentrations determined by instrumental neutron activation by abbreviated count (INAA) analyses of core samples collected from the East Bay Bayside Monitoring Site borehole, San Lorenzo, California.

23. Summary statistics for inductively coupled plasma-mass spectroscopy (ICP-MS) and instrumental neutron activation by abbreviated count (INAA) analyses and method comparison from core samples from the East Bay Bayside Monitoring Site borehole, San Lorenzo, California.

24. Summary of water quality indicators, alkalinity, and dissolved inorganic carbon for pore water extracted from selected East Bay Bayside Monitoring Site core ......

25. Concentrations of major ions in pore water extracted from selected East Bay Bayside Monitoring Site core. 


\section{Tables-Continued}

26. Trace metals in pore water extracted from selected East Bay Bayside Monitoring Site core and analyzed by the U.S. Geological Survey National Water Quality Laboratory, Denver, Colorado

27. Stable isotope ratios of hydrogen and oxygen in pore water extracted from selected East Bay Bayside Monitoring Site core and analyzed by U.S. Geological Survey-National Research Program, Stable Isotope Laboratory, Reston, Virginia

\section{Conversion Factors, Abbreviations, and Acronyms}

\begin{tabular}{|c|c|c|}
\hline Multiply & By & To obtain \\
\hline \multicolumn{3}{|c|}{ Length } \\
\hline inch (in.) & 2.54 & centimeter $(\mathrm{cm})$ \\
\hline inch (in.) & 25.4 & millimeter $(\mathrm{mm})$ \\
\hline inch (in.) & 25400 & micrometer $(\mu \mathrm{m})$ \\
\hline foot $(\mathrm{ft})$ & 0.3048 & meter $(\mathrm{m})$ \\
\hline mile (mi) & 1.609 & kilometer $(\mathrm{km})$ \\
\hline \multicolumn{3}{|c|}{ Area } \\
\hline square foot $\left(\mathrm{ft}^{2}\right)$ & 929.0 & square centimeter $\left(\mathrm{cm}^{2}\right)$ \\
\hline square foot $\left(\mathrm{ft}^{2}\right)$ & 0.09290 & square meter $\left(\mathrm{m}^{2}\right)$ \\
\hline square inch $\left(\mathrm{in}^{2}\right)$ & 6.452 & square centimeter $\left(\mathrm{cm}^{2}\right)$ \\
\hline square mile $\left(\mathrm{mi}^{2}\right)$ & 259.0 & hectare (ha) \\
\hline square mile $\left(\mathrm{mi}^{2}\right)$ & 2.590 & square kilometer $\left(\mathrm{km}^{2}\right)$ \\
\hline \multicolumn{3}{|c|}{ Volume } \\
\hline million gallons (Mgal) & 3,785 & cubic meter $\left(\mathrm{m}^{3}\right)$ \\
\hline cubic inch $\left(\mathrm{in}^{3}\right)$ & 16.39 & cubic centimeter $\left(\mathrm{cm}^{3}\right)$ \\
\hline cubic inch $\left(\mathrm{in}^{3}\right)$ & 0.01639 & liter (L) \\
\hline cubic foot $\left(\mathrm{ft}^{3}\right)$ & 0.02832 & cubic meter $\left(\mathrm{m}^{3}\right)$ \\
\hline acre-foot (acre-ft) & 1,233 & cubic meter $\left(\mathrm{m}^{3}\right)$ \\
\hline \multicolumn{3}{|c|}{ Flow rate } \\
\hline million gallons per day (Mgal/d) & 0.04381 & cubic meter per second $\left(\mathrm{m}^{3} / \mathrm{s}\right)$ \\
\hline \multicolumn{3}{|c|}{ Mass } \\
\hline ounce, avoirdupois (oz) & 28.35 & gram $(\mathrm{g})$ \\
\hline ounce, avoirdupois (oz) & $28,349.5$ & milligram (mg) \\
\hline \multicolumn{3}{|c|}{ Pressure } \\
\hline atmosphere, standard (atm) & 101.3 & kilopascal (kPa) \\
\hline bar & 100 & kilopascal (kPa) \\
\hline pound per square foot $\left(\mathrm{lb} / \mathrm{ft}^{2}\right)$ & 0.04788 & kilopascal (kPa) \\
\hline pound per square inch $\left(\mathrm{lb} / \mathrm{in}^{2}\right)$ & 6.895 & kilopascal (kPa) \\
\hline
\end{tabular}




\section{Conversion Factors, Abbreviations, and Acronyms-Continued}

\begin{tabular}{lcc}
\hline \multicolumn{1}{c}{ Multiply } & By & \multicolumn{1}{c}{ To obtain } \\
\hline pound per cubic foot $\left(\mathrm{lb} / \mathrm{ft}^{3}\right)$ & Density & \\
pound per cubic foot $\left(\mathrm{lb} / \mathrm{ft}^{3}\right)$ & 16.02 & kilogram per cubic meter $\left(\mathrm{kg} / \mathrm{m}^{3}\right)$ \\
& 0.01602 & gram per cubic centimeter $\left(\mathrm{g} / \mathrm{cm}^{3}\right)$ \\
\hline foot per day $(\mathrm{ft} / \mathrm{d})$ & Hydraulic conductivity & \\
foot per second $(\mathrm{ft} / \mathrm{s})$ & 0.3048 & meter per day $(\mathrm{m} / \mathrm{d})$ \\
& 0.3048 & meter per second $(\mathrm{m} / \mathrm{s})$ \\
\hline picocurie per liter $(\mathrm{pCi} / \mathrm{L})$ & Radioactivity & \\
\hline
\end{tabular}

Temperature in degrees Celsius $\left({ }^{\circ} \mathrm{C}\right)$ may be converted to degrees Fahrenheit $\left({ }^{\circ} \mathrm{F}\right)$ as follows: ${ }^{\circ} \mathrm{F}=\left(1.8 x^{\circ} \mathrm{C}\right)+32$

Vertical coordinate information is referenced to the North American Vertical Datum of 1988 (NAVD 88).

Horizontal coordinate information is referenced to the North American Datum of 1983 (NAD 83). Altitude, as used in this report, refers to distance above the vertical datum.

Specific conductance is given in microsiemens per centimeter at 25 degrees Celsius $(\mu \mathrm{S} / \mathrm{cm}$ at $\left.25^{\circ} \mathrm{C}\right)$.

Concentrations of chemical constituents in water are given either in milligrams per liter (mg/L) or micrograms per liter $(\mu \mathrm{g} / \mathrm{L})$.

\section{Abbreviations and Acronyms}

ASR

aquifer storage and recovery

ASTM

American Society for Testing and Materials

BGP

Bayside Groundwater Project

DIC

dissolved inorganic carbon

EBAY

East Bay Bayside Monitoring Site

EBMUD

East Bay Municipal Utility District

EBMY

East Bay Mud Yard

EBSP

East Bay Stenzel Park

EDS

energy dispersive spectroscopy

EXT1

East Bay Extensometer-1 Monitoring Site

EXT2

East Bay Extensometer-2 Monitoring Site

fbls feet below land surface 
Abbreviations and Acronyms-Continued

\begin{tabular}{ll} 
ICP-MS & inductively coupled plasma-mass spectroscopy \\
INAA & instrumental neutron activation by abbreviated count \\
IRSL & infrared stimulated luminescence \\
kV & kilovolts \\
MSCL & multi-sensor core logger \\
mV & millivolts \\
nA & nanoamp \\
NAWQA & National Water-Quality Assessment \\
NOSAMS & National Ocean Sciences AMS Facility \\
NTRU & nephelometric turbidity ratio units \\
NWIS & National Water Information System \\
NWOL & National Water Quality Laboratory \\
OSL & optically stimulated luminescence \\
pSU & practical salinity units \\
PVC & polyvinyl chloride \\
R & coefficient of determination \\
SCPT & seismic cone penetration test \\
SEM & scanning electron microscopy \\
TDS & total dissolved solids \\
TRIGA & Training, Research, Isotopes, General Atomics \\
UAMSL & University of Arizona Accelerator Mass Spectrometry Lab \\
USGS & U.S. Geological Survey \\
UWIL & University of Waterloo Environmental Isotope Lab \\
$V_{p}$ & velocity of P waves \\
$V_{s}$ & velocity of S waves \\
XRD & X-ray diffraction \\
YMPB & \\
& Yucca Mountain Project Branch \\
\hline
\end{tabular}




\title{
Lithostratigraphic, Borehole-Geophysical, Hydrogeologic, and Hydrochemical Data from the East Bay Plain, Alameda County, California
}

\author{
By Michelle Sneed, Patricia v.P. Orlando, James W. Borchers, Rhett Everett, Mike Solt, Mary McGann, \\ Heather Lowers, and Shannon Mahan
}

\section{Abstract}

The U.S. Geological Survey, in cooperation with the East Bay Municipal Utility District, carried out an investigation of aquifer-system deformation associated with groundwater-level changes at the Bayside Groundwater Project near the modern San Francisco Bay shore in San Lorenzo, California. As a part of the Bayside Groundwater Project, East Bay Municipal Utility District proposed an aquifer storage and recovery program for 1 million gallons of water per day. The potential for aquifer-system compaction and expansion, and related subsidence, uplift, or both, resulting from aquifer storage and recovery activities were investigated and monitored in the Bayside Groundwater Project. In addition, baseline analysis of groundwater and substrata properties were performed to assess the potential effect of such activities. Chemical and physical data, obtained from the subsurface at four sites on the east side of San Francisco Bay in the San Lorenzo and San Leandro areas of the East Bay Plain, Alameda County, California, were collected during the study. The results of the study were provided to the East Bay Municipal Utility District and other agencies to evaluate the chemical and mechanical responses of aquifers underlying the East Bay Plain to the future injection and recovery of imported water from the Sierra Nevada of California.

Among 4 sites, 14 piezometers and 2 extensometers were installed in 6 boreholes, which ranged in depth from 460 to 1,040 feet. The lithology of drill cuttings, collected at 5- or 10 -foot intervals, was described for grain size and any other noticeable features, such as wood or shell fragments. Borehole geophysical logging was performed at each site in the deepest borehole, immediately following drilling.

Drill-core samples, totaling 284 feet, were collected at the Bayside site. The drill-core sediment was subsampled to determine pore-water chemistry, vertical hydraulic conductivity, and physical and mechanical properties at different depths. Depositional environment and age were determined by luminescence geochronology and fossil identification. The elemental composition of the drill-core sediments was determined by inductively coupled plasma mass spectroscopy and instrumental neutron activation by abbreviated count analysis. Mineral composition was determined by X-ray diffraction and scanning electron microscopy analysis.

Groundwater samples were collected from all 14 piezometers as part of either the USGS Groundwater Ambient Monitoring and Assessment or the USGS National Water Quality Assessment program for water-quality analyses. Sample analytes included nutrients, major and minor ions, trace elements, isotopic ratios of hydrogen and oxygen in water, carbon-14, and tritium.

Water-level and aquifer-system-compaction measurements, which indicated diurnal and seasonal fluctuations, were made at the Bayside Groundwater Project site. Slug tests were performed at the Bayside piezometers and nine pre-existing wells to estimate hydraulic conductivity.

\section{Introduction}

Aquifer-system deformation associated with groundwater-level changes was investigated cooperatively by the U.S. Geological Survey (USGS) and the East Bay Municipal Utility District (EBMUD) at the Bayside Groundwater Project (BGP) in San Lorenzo, California, near the San Francisco Bay shore (fig. 1). As a part of the BGP, EBMUD has proposed an aquifer storage and recovery (ASR) program for injecting 1 million gallons of imported water per day. This water will be stored in a 98 -foot (ft) -thick sequence of coarse-grained sediment (referred to in this report as the "Deep aquifer") underlying the East Bay Plain and the neighboring groundwater basin. Water from the Deep aquifer could be used directly to help meet short-term needs arising from drought, seismic, and other water-supply emergencies. In addition, water imported from the Sierra Nevada could be injected, stored, and later recovered from the Deep aquifer for public supply. Land-surface uplift and subsidence at the ASR site and surrounding areas resulting from the expansion 


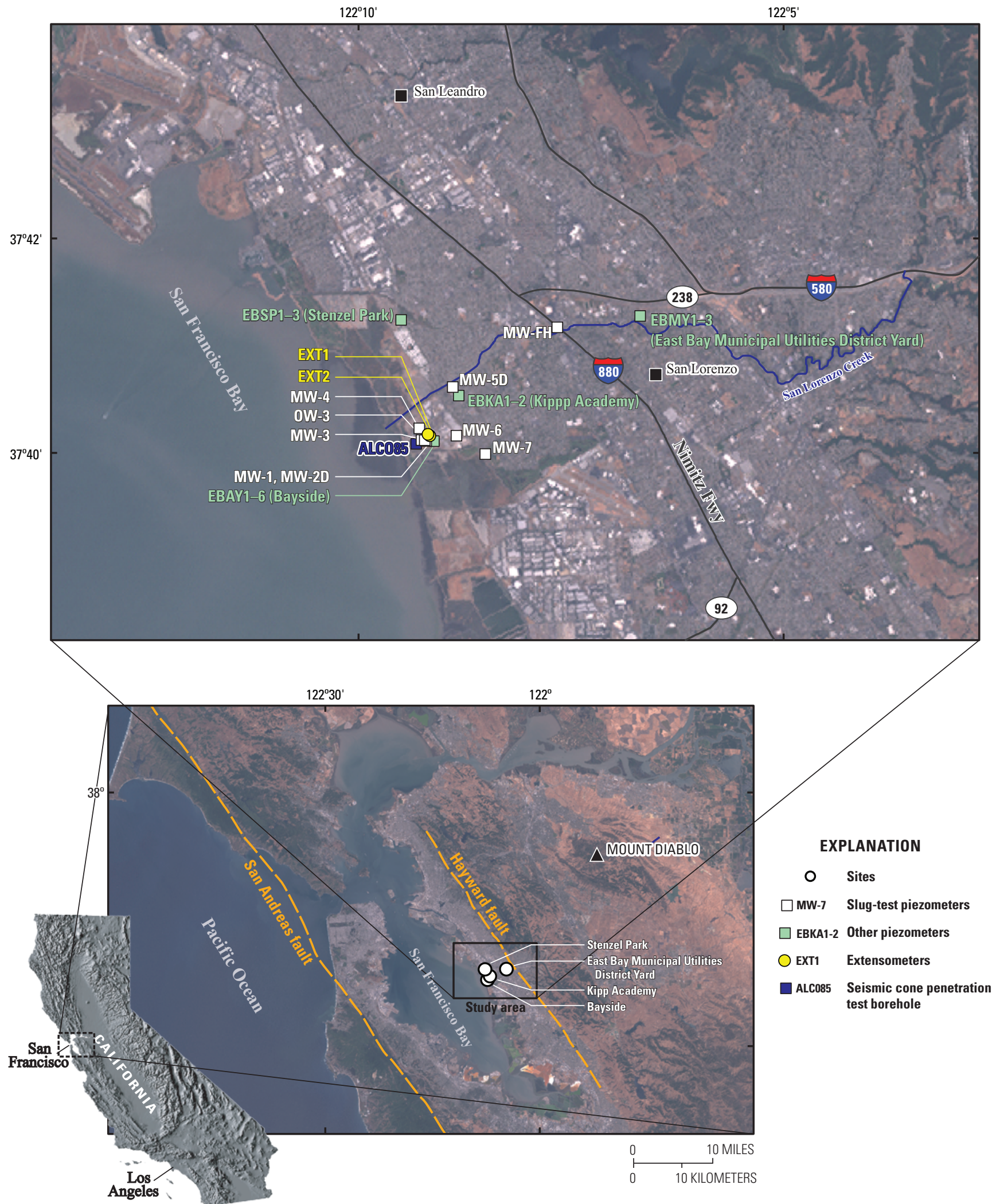

Figure 1. Map showing tThe piezometer, extensometer, and slug-test locations, East Bay Plain, Alameda County, California. 
and compression of the aquifer system associated with water injection and pumping during ASR cycles could occur. In addition, the introduction of imported water that has a different chemical composition from native water could alter the chemical equilibrium between the groundwater and the substrate. Chemical analyses of the groundwater and sediments were performed at select sites in order to establish a baseline of water quality.

The Deep aquifer is overlain by about $500 \mathrm{ft}$ of clayey, fine-grained sediments and underlain by comparable sediments. These sediments are similar to the clayey sediments found in the nearby Santa Clara Valley, where inelastic compaction resulted in about $14 \mathrm{ft}$ of subsidence near San Jose from 1910 to 1995 due to overdraft of the aquifer (Galloway and others, 1999). The Deep aquifer is an important regional resource, and EBMUD is required to demonstrate that ASR activities will not cause permanent land subsidence or adversely affect nearby groundwater management or salinity levels. Because local relief is low, subsidence in the East Bay area could induce coastal flooding and create difficulty conveying winter storm runoff from urbanized areas.

The objectives of this investigation were to monitor and analyze aquifer-system compaction and expansion, and any related subsidence or uplift, resulting from proposed
ASR activities at the BGP and to establish a baseline of groundwater quality prior to injection. For this purpose, 14 piezometers and 2 extensometers were constructed to monitor groundwater levels, groundwater chemistry, and aquifer-system compaction. This information is needed by the EBMUD for the planning and implementation of large-scale injection and recovery operations.

As an initial step to achieve this objective, the USGS drilled three boreholes at one site (Bayside) next to the BGP. Inside one of the boreholes, refered to as the East Bay Bayside Monitoring Site (EBAY), six piezometers (EBAY 1-6) were constructed, and in the other two boreholes (East Bay Extensometer-1 Monitoring Site, or EXT1, and East Bay Extensometer-2 Monitoring Site, or EXT2), a dual-stage extensometer was installed at depths of about 700 and $1,040 \mathrm{ft}$. Additional boreholes were drilled at three sites near the BGP - the East Bay MUD Yard (EBMY), Stenzel Park (EBSP), and Kipp Academy (EBKA) - and constructed with two or three piezometers each (table 1). These piezometers and extensometers were constructed for the purpose of monitoring pore-fluid pressure changes and aquifer-system deformation, respectively, which could result from the proposed ASR program.

Table 1. Summary of sites, boreholes, piezometers, and types of data collected for the Bayside Groundwater Project with table and figure references.

[Abbreviations: fbls, feet below land surface; MUD, Municipal Utility District; —, no data]

\begin{tabular}{|c|c|c|c|c|c|c|c|c|}
\hline $\begin{array}{c}\text { Site } \\
\text { name }\end{array}$ & $\begin{array}{c}\text { Borehole } \\
\text { name } \\
\text { (depth in fbls) }\end{array}$ & $\begin{array}{l}\text { Piezometers } \\
\text { (number } \\
\text { in each } \\
\text { borehole) }\end{array}$ & Extensometer & $\begin{array}{l}\text { Lithological } \\
\text { and } \\
\text { geophysical } \\
\text { logs }\end{array}$ & $\begin{array}{l}\text { Water level and } \\
\text { aquifer-system } \\
\text { compaction }\end{array}$ & $\begin{array}{l}\text { Slug } \\
\text { tests }\end{array}$ & $\begin{array}{c}\text { Water- } \\
\text { quality data }\end{array}$ & $\begin{array}{c}\text { Core } \\
\text { analysis }\end{array}$ \\
\hline Bayside & $\begin{array}{c}\text { EBAY } \\
(1,040)\end{array}$ & 6 & - & Fig. $2 A$ & Fig. $4 A$ & Table 2,5 & Table $2,6-10$ & Table 11-27 \\
\hline Bayside & $\begin{array}{c}\text { EXT1 } \\
(1,040)\end{array}$ & 0 & Fig. 3 & Fig. $2 B$ & Fig. $4 B$ & - & - & - \\
\hline Bayside & ALC085 & 0 & - & -1 & - & - & - & $-^{1}$ \\
\hline East Bay MUD yard & $\begin{array}{c}\text { EBMY } \\
(460)\end{array}$ & 3 & - & Fig. $2 D$ & - & - & Table $2,6-10$ & - \\
\hline Kipp academy & $\begin{array}{l}\text { EBKA } \\
(460)\end{array}$ & 2 & - & Fig. $2 E$ & - & - & Table $2,6-10$ & - \\
\hline Slug site 2 & MW-1 & 1 & - & - & - & Table 2, 5 & - & - \\
\hline Slug site 3 & MW-2D & 2 & - & - & - & Table 2, 5 & - & - \\
\hline Slug site 4 & OW3 & 1 & - & - & - & Table 2, 5 & - & - \\
\hline Slug site 5 & MW-3 & 1 & - & - & - & Table 2,5 & - & - \\
\hline Slug site 6 & MW-4 & 1 & - & - & - & Table 2, 5 & - & - \\
\hline Slug site 7 & MW-5D & 1 & - & - & - & Table 2,5 & - & - \\
\hline Slug site 8 & MW-6 & 1 & - & - & - & Table 2, 5 & - & - \\
\hline Slug site 9 & MW-7 & 1 & - & - & - & Table 2, 5 & - & - \\
\hline
\end{tabular}

${ }^{1}$ Data for this borehole is presented in Bennett and others, 2009. 
Lithostratigraphic, Borehole-Geophysical, Hydrogeologic, and Hydrochemical Data from the East Bay Plain

\section{Purpose and Scope}

The purpose of this report is to present chemical and physical data obtained from the subsurface at four sites in the East Bay Plain of Alameda County-East Bay Bayside (EBAY, EXT1, EXT2, and ALC085); East Bay MUD Yard (EBMY); Stenzel Park (EBSP); and Kipp Academy (EBKA). The data included lithologic descriptions, geophysical logs, and results of groundwater-quality analyses from each of the four sites. In addition, analyses of drill-core sediments, extensometer measurements, and groundwater-level measurements from the Bayside sites are presented. Furthermore, slug-test results from the Bayside and nine other pre-existing wells are presented. These data are for use by EBMUD and other agencies to evaluate the response of aquifers underlying the East Bay Plain to the injection and recovery of imported water from the Sierra Nevada.

The scope of the report includes descriptions of drilling and constructing piezometers and a dual-stage extensometer, collecting and analyzing chemical and physical data from the subsurface, performing and analyzing slug tests from selected new and existing wells, and measuring groundwater levels and compaction at the Bayside site. A second phase of this project has been proposed and includes production of a report that documents the hydromechanical analyses of the data presented in this report and of any high-quality data collected subsequent to publication of this report.

\section{Previous Studies}

The EBMUD has carried out a series of studies to evaluate the geologic and hydraulic properties of local deep aquifers. The purpose of these studies was to determine the yield of wells in these aquifers and to assess their suitability for injection and recovery of imported water. Most of this work has been site specific and related to the installation and performance of injection and recovery wells (Fugro West, Inc., 1998, 1999), although a regional assessment of subsurface geohydrologic conditions has been completed (CH2M-Hill Inc., 2000). Izbicki and others (2003) presented additional data and a comprehensive understanding of the geohydrology and geochemistry of the aquifer system to assist water-resources managers in the planning and implementation of large-scale injection and recovery operations in aquifers underlying the East Bay Plain. Catchings and others (2006) used seismic imaging to better understand the subsurface stratigraphy and structures and their effects on groundwater and earthquake hazards. Brocher and others (2007) characterized seismic hazards at Bayside by using shear-wave and compressionalwave suspension logging. Bennett and others (2009) used seismic cone-penetration tests (SCPT) at Bayside to determine stratification, soil type, shear-wave velocity, density, consistency, and penetration resistence. Water-quality and quality-assurance samples were collected at the six EBAY piezometers at the Bayside site in June 2007 and analyzed as part of the USGS Groundwater Ambient Monitoring and Assessment (GAMA) program (Ray and others, 2009).

\section{Description of the Study Area}

The study area is on the east side of the San Francisco Bay in the San Lorenzo and San Leandro areas of the East Bay Plain (fig. 1), which consists of about 120 square miles $\left(\mathrm{mi}^{2}\right)$ of tidal marshes and alluvial lowlands. San Lorenzo Creek is the principal stream in the study area, draining $44 \mathrm{mi}^{2}$, originating in the Diablo Range, and flowing westward to the San Francisco Bay. The study area has a Mediterranean climate with mild, wet winters and warm, dry summers. The average annual temperature is 13.2 degrees Celsius $\left({ }^{\circ} \mathrm{C}\right)$ : average winter temperatures (December-February) are about $9^{\circ} \mathrm{C}$, and average summer (June-August) temperatures are about $15^{\circ} \mathrm{C}$. Most precipitation falls as rain between November and March, and precipitation averages 23 inches (in.) annually (Muir, 1997). In 1999, the East Bay Plain had a population of more than 900,000 (San Francisco Bay Regional Water Quality Control Board, 1999). The area is densely populated and highly urbanized and is characterized by industrial, commercial, and residential land uses. Although agriculture was important in the past, there is little agricultural land use in the study area at the present time (Izbicki and others, 2003).

\section{Hydrogeologic Framework}

The study area is located in a structural depression underlying San Francisco Bay that is bounded by the San Andreas fault to the west and the Hayward fault to the east (Trask and Rolston, 1951; Sedlock, 1995; Marlow and others, 1999). The thickest deposits in the study area are near San Leandro, along the margin of San Francisco Bay (Rogers and Figuers, 1991; Marlow and others, 1999), and deposits thin to the north. Deeper deposits within this structural depression have been compressed and folded as a result of movement along the faults (Marlow and others, 1999). During the last 130,000 years or more, the areal extent of the San Francisco Bay has been controlled by sea-level changes, geologic movement along faults, and sedimentation from upland streams. These processes produced a complex sequence of coarse-grained aquifers and fine-grained confining layers (Koltermann and Gorelick, 1992).

The study area is on part of the East Bay Plain that is composed of the alluvial fan of San Lorenzo Creek (fig. 1), which is underlain by a complex inter-fingering sequence 
of late Pleistocene to Holocene unconsolidated marine and continental deposits (Brown and Caldwell, Inc., 1986; CH2M-Hill, Inc., 2000). The marine deposits primarily consist of estuarine mud and salt-marsh deposits that include the Young Bay Mud; the Old Bay Mud, also known as the Yerba Buena Mud (Sloan, 1992); and several other units (Trask and Rolston, 1951; Ross, 1977; Atwater and others, 1981; Rogers and Figuers, 1991; Sloan, 1992; CH2M-Hill Inc., 2000). The continental deposits consist of coarse-grained stream-channel deposits and finer-grained flood-plain deposits (Koltermann and Gorelick, 1992; Sloan, 1992), which compose the coalescing alluvial fans of San Leandro and San Lorenzo Creeks and other drainages along the east side of San Francisco Bay. Partly consolidated sedimentary rocks and deposits probably underlie the late Pleistocene continental and marine deposits (Marlow and others, 1999; Izbicki and others, 2003). Basement rocks are assumed to be the same as those found in the neighboring mountain ranges, which consist largely of Mesozoic "Great Valley" and "Franciscan" complexes and overlying Tertiary and younger rocks (Howard, 1979; Graymer, 2000).

The four primary aquifers in the study area consist of aeolian sand, alluvial sand, and gravel deposits separated by estuarine mud or fine-grained, alluvial flood-plain deposits. In many areas, the aquifers are discontinuous, and it is difficult to correlate sand and gravel layers over great distances between wells. In the study area, the aquifers are named (from shallowest to deepest) the Newark, Centerville, Freemont, and Deep aquifers (Izbicki and others, 2003). The aquifers in this study are the "time-equivilent" counterparts of aquifers in the alluvial fans of Alameda Creek, originally named by Brown and Caldwell (1986) and Maslonkowski (1988) and commonly known as the Niles Cone basin. It is not known if they are hydraulically connected to aquifers in the Niles Cone basin, which is approximately 15 miles to the south.

The Newark aquifer is present to a depth of 30 to 130 feet below land surface (fbls) throughout the study area (CH2MHill Inc., 2000). Water in the Newark aquifer is generally confined, except near recharge areas along the mountain front. The underlying Centerville aquifer is about $100-\mathrm{ft}$ thick and extends to depths of about $220 \mathrm{fbls}$ (Maslonkowski, 1984). In the Niles Cone basin, the Freemont aquifer is a generic name for discontinuous sand and gravel deposits between 240 and $400 \mathrm{fbls}$. In the study area, the name has been applied to sand and gravel deposits as deep as $500 \mathrm{ft}$ by $\mathrm{CH} 2 \mathrm{M}$-Hill, Inc. (2000). The Deep aquifer occurs between 500 and $650 \mathrm{fbls,}$ and in some areas it is as much as $140-\mathrm{ft}$ thick. The Deep aquifer is thickest and most continuous south of San Leandro (Maslonkowski, 1988) and thins, eventually disappearing, to the north (CH2M-Hill, Inc., 2000). In this area, aquifers are underlain by partly consolidated deposits (Marlow and others, 1999) that have low values of porosity and permeability.

\section{Methods}

\section{Design of Monitoring Sites}

A total of 14 piezometers and 2 extensometers were constructed among six boreholes distributed among four sites: Bayside (EBAY, EXT1, EXT2), East Bay MUD Yard (EBMY), Kipp Academy (EBKA), and Stenzel Park (EBSP; fig. 1, table 1). Boreholes were drilled by using a hydraulic mud rotary rig operated by the USGS Western Region Research Drilling Unit. The four piezometer boreholes (EBAY, EBMY, EBKA, EBSP) are telescoping-diameter designs, where diameters range from 22 to 7.875 in., with the largest drilled diameter at the land surface and smallest drilled diameter at final depth. Borehole depths ranged from 460 to 1,040 fbls. At the Bayside site, 15-in. surface conductor casing was installed in the EBAY borehole to $100 \mathrm{fbls}$, and 14-in. surface conductor casing was installed in the EXT1 and EXT2 boreholes to $79 \mathrm{fbls}$. A summary of sites, boreholes, and types of data collected from each can be found in table 1 .

\section{Piezometer Construction and Instrumentation}

The 14 piezometers at the 4 sites were constructed as nested, 2 -in. or 2.5 -in. diameter, schedule 80 polyvinyl chloride (PVC) casings, with 10- to 60-ft slotted-screen intervals; slot size was 1.2 by 0.02 inches, width by height, respectively. Screened intervals were sand packed by using a tremmie pipe with \#3 Monterey sand; all other intervals were grouted with a 30 -percent-solids bentonite grout to hydraulically isolate the sand packs and seal the boreholes from surface infiltration. The uppermost parts of the piezometers were encased in protective underground vaults fitted with locking lids for security purposes. The piezometers were developed by using an air-lifting and surging technique until no drilling mud was visible in the discharge and several water-quality parameters (specific conductance, $\mathrm{pH}$, temperature) had stabilized. Construction diagrams for the piezometers are shown in figure 2. Although six piezometers were constructed in the EBAY borehole, the deepest piezometer (EBAY1) was not developed sufficiently and, therefore, was not responsive. Upon completion of EBAY1 piezometer construction, test equipment could not be lowered past a depth of $1,000 \mathrm{ft}$ into the 2.5 -in. PVC piezometer casing. Repeated attempts were made to clear the 1,000 to $1,010 \mathrm{ft}$ interval by using airlifting techniques; however, by January 2008, silt filled the bottom $60 \mathrm{ft}$ of the piezometer, including the screened interval, which, therefore, was not well-connected to the aquifer system. As a result of this malfunction, results of analyses from piezometer EBAY1 are not discussed. 
$\boldsymbol{A}$

East Bay Bayside Monitoring Site (EBAY)

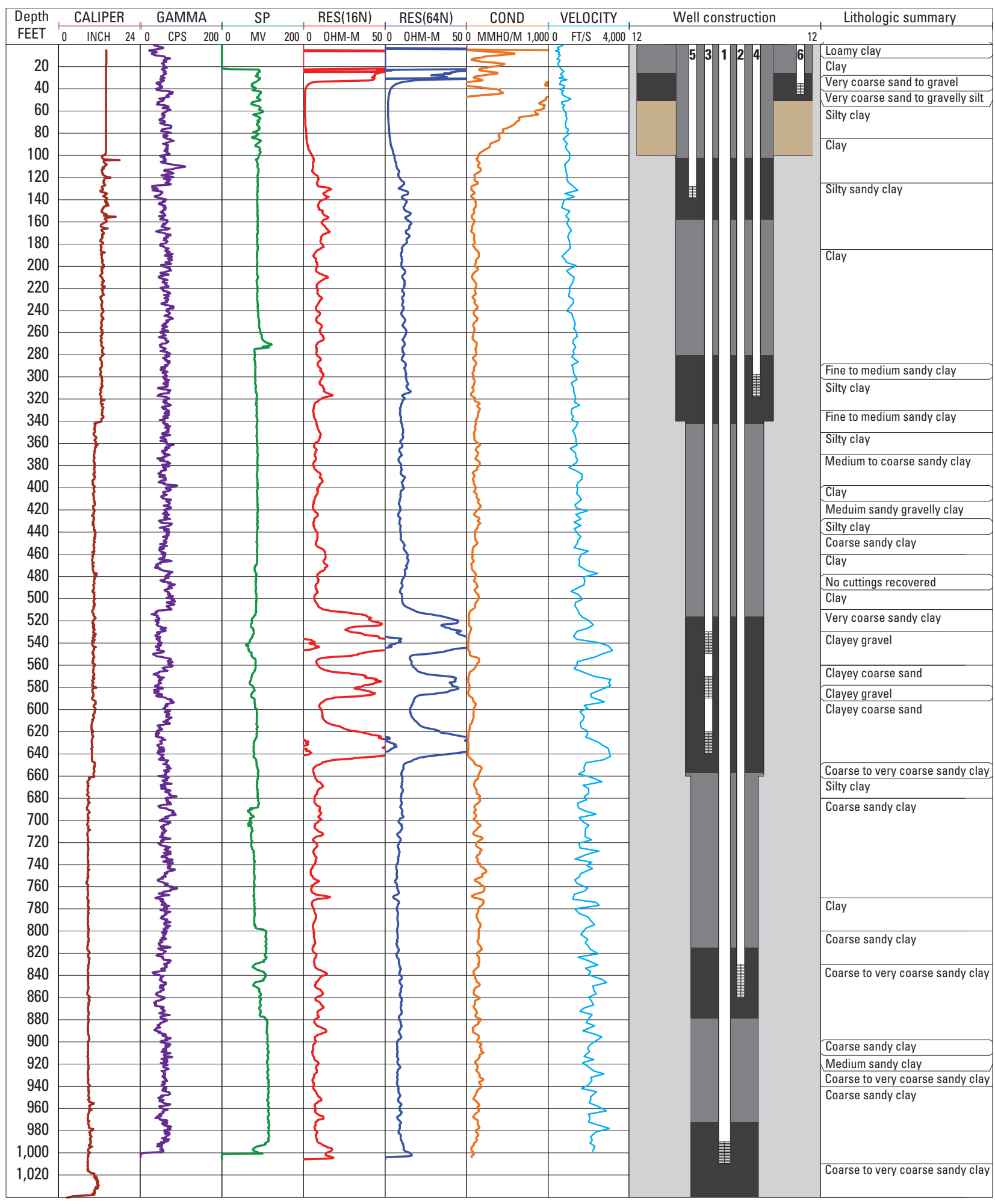

EXPLANATION

Portland cement

\#3 RMC sand

Bentonite grout at 30-percent solids

Well screen 1.5 inches by 0.020 feet

Native soil

[Abbreviations: CPS, counts per second; MV, millivolts; OHM-M, ohm-meter; MMMHO/M, millimho per meter; FT/S, feet per second; SP, spontaneous potential]

Figure 2. Graphs showing wWell construction and lithological, geophysical, and velocity logs for East Bay monitoring sites: $A$, East Bay Bayside Monitoring Site (EBAY); $B$, East Bay Extensometer-1 Monitoring Site (EXT1) at Bayside; $C$, East Bay Extensometer-2 Monitoring Site (EXT2) at Bayside; D, East Bay Municipal Utility District Yard (EBMY); E, Kipp Academy (EBKA); and $F$, Stenzel Park (EBSP). 


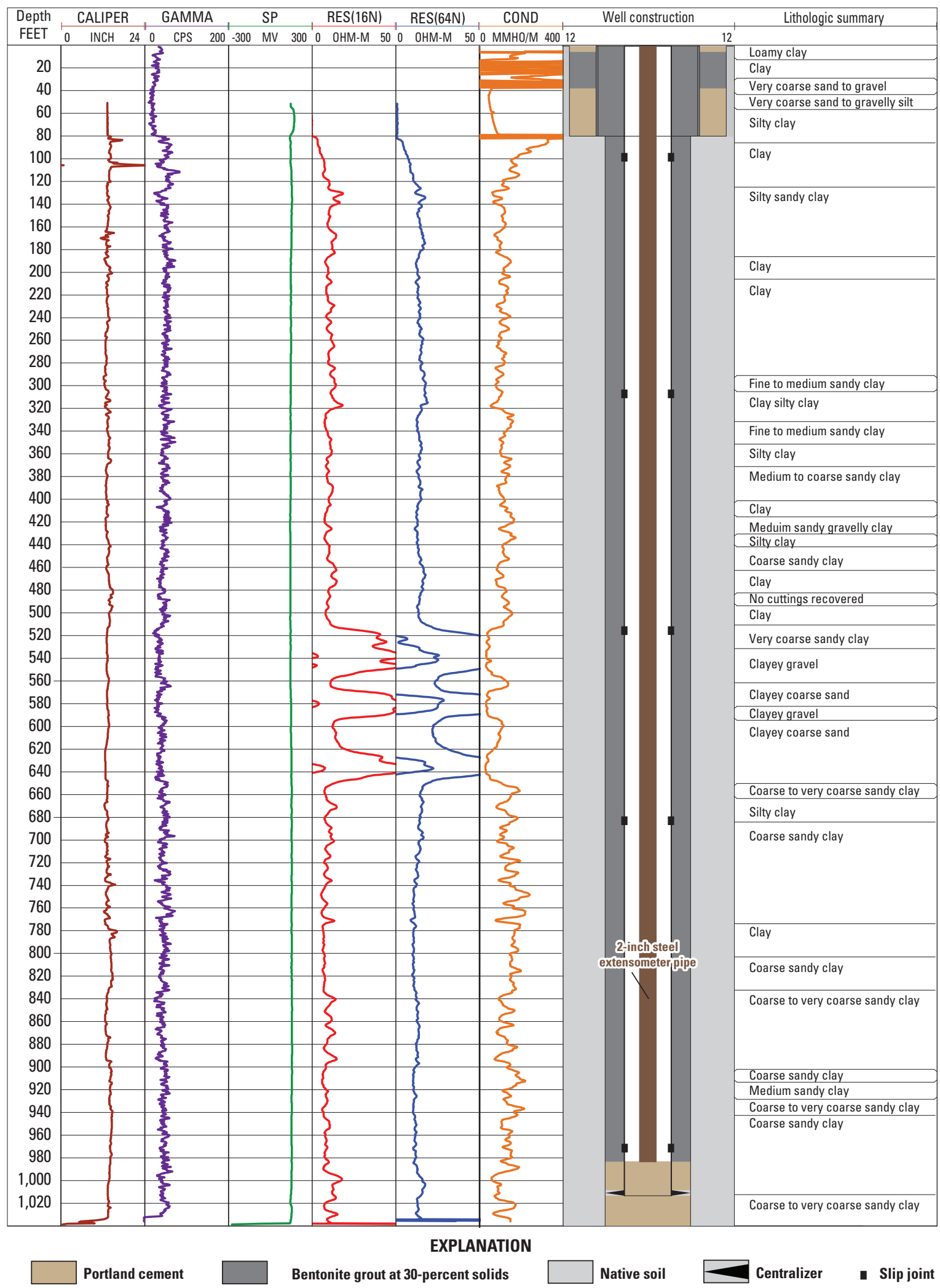

[Abbreviations: CPS, counts per second; MV, millivolts; OHM-M, ohm-meter; MMMHO/M, millimho per meter; FT/S, feet per second; SP, spontaneous potential]

Figure 2. - Continued 
C

East Bay Extensometer-2 Monitoring Site (EXT2)

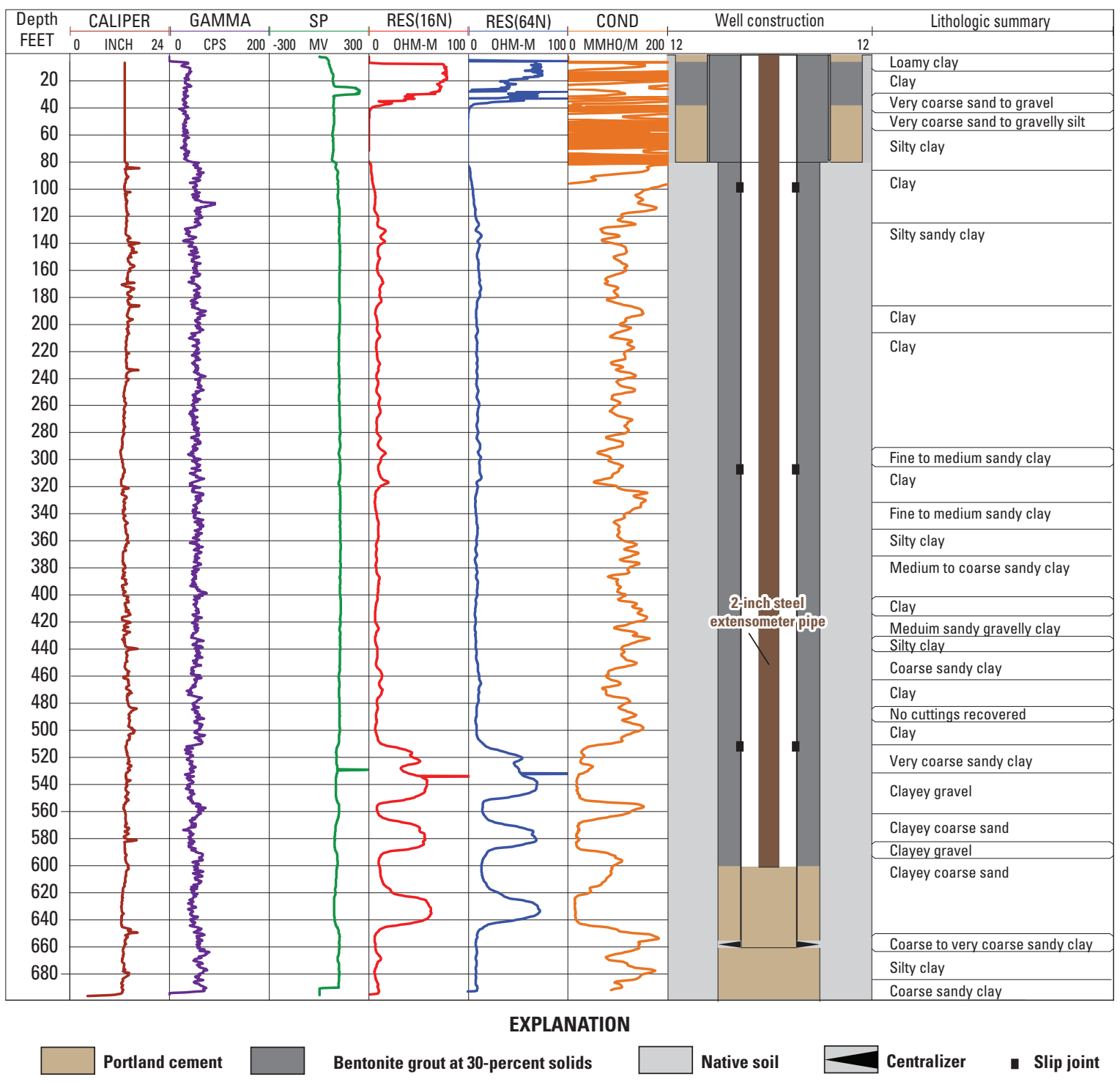

[Abbreviations: CPS, counts per second; MV, millivolts; OHM-M, ohm-meter; MMMHO/M, millimho per meter; FT/S, feet per second; SP, spontaneous potential]

Figure 2. - Continued 


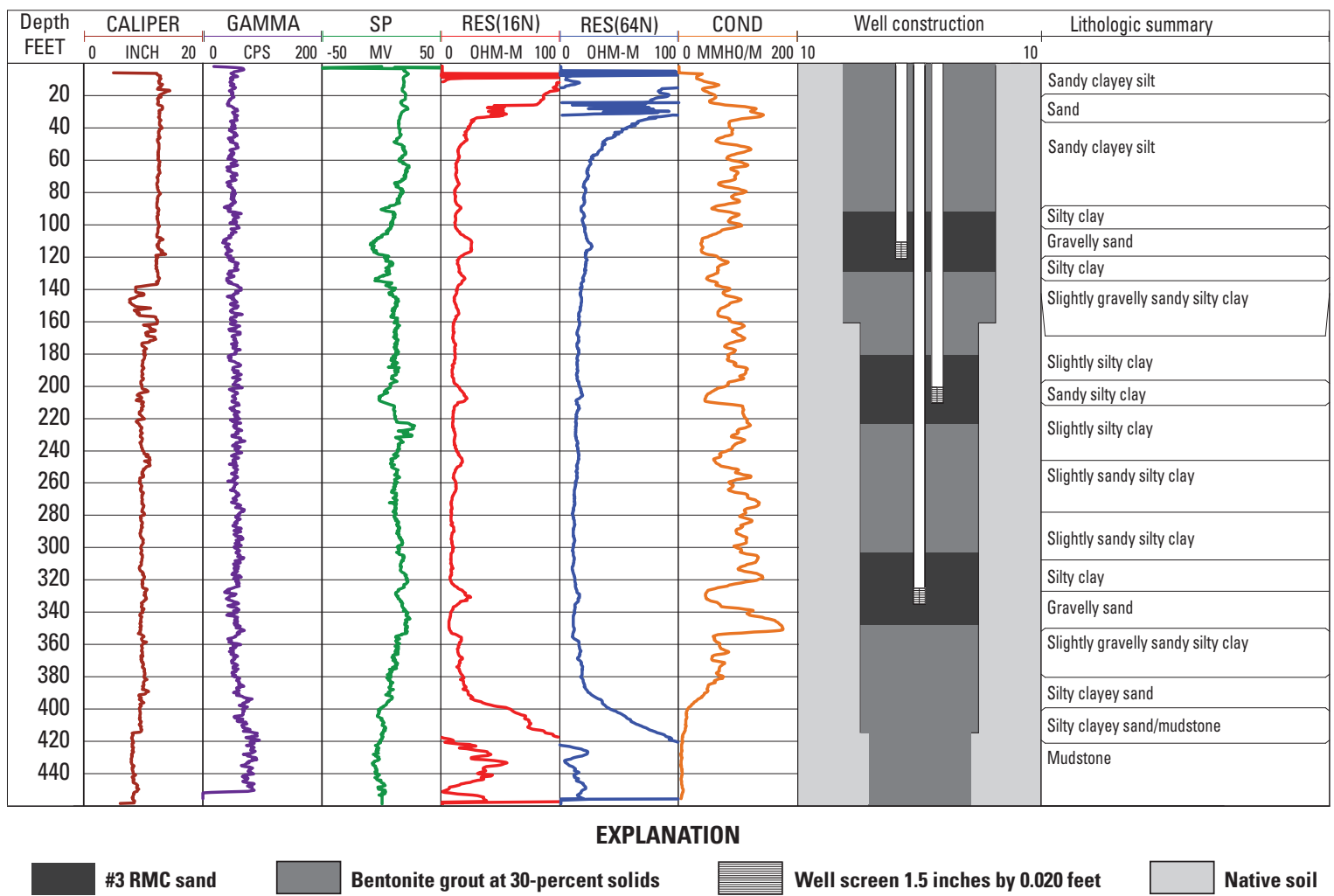

[Abbreviations: CPS, counts per second; MV, millivolts; OHM-M, ohm-meter; MMMHO/M, millimho per meter; FT/S, feet per second; SP, spontaneous potential]

Figure 2. - Continued 


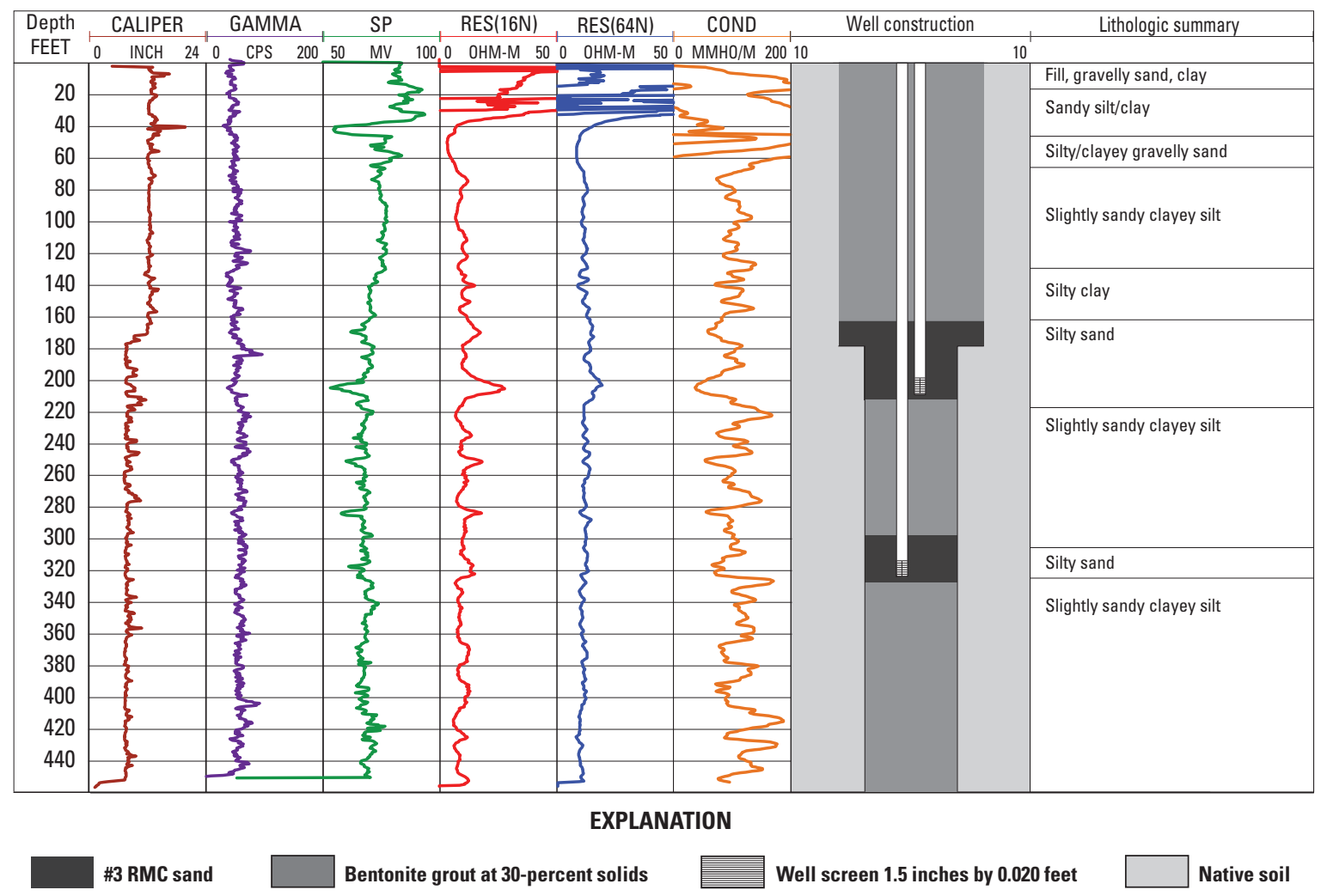

[Abbreviations: CPS, counts per second; MV, millivolts; OHM-M, ohm-meter; MMMHO/M, millimho per meter; FT/S, feet per second; SP, spontaneous potential]

Figure 2. - Continued 


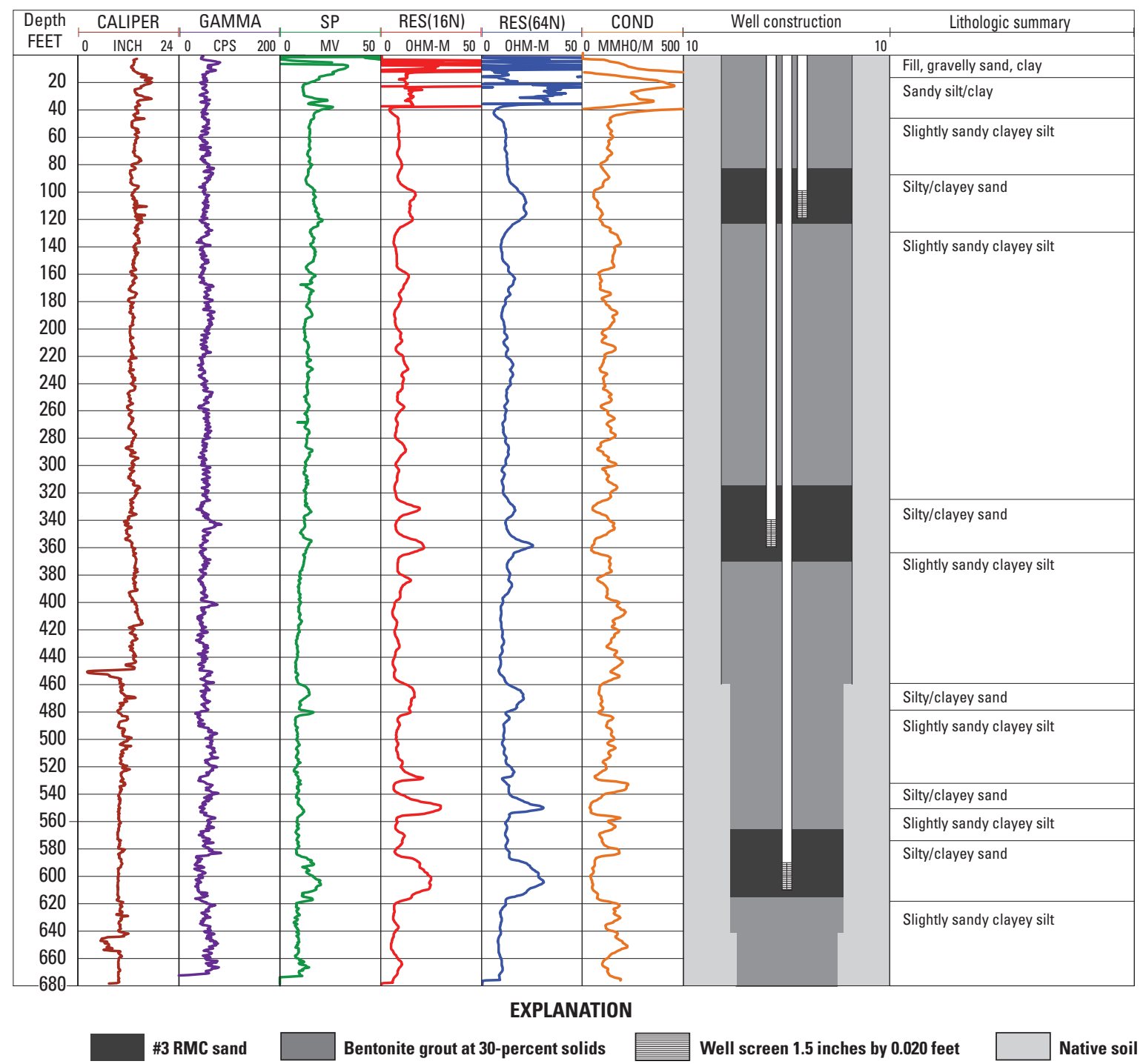

[Abbreviations: CPS, counts per second; MV, millivolts; OHM-M, ohm-meter; MMMHO/M, millimho per meter; FT/S, feet per second; SP, spontaneous potential]

Figure 2. - Continued 
Submersible, vented, 10-pound per square inch (psi) pressure transducers and data loggers were installed to continuously measure and record water levels in the six EBAY piezometers. EBMY, EBSP, and EBKA data are managed by EBMUD and were not instrumented by the USGS. To prevent moisture from condensing in the vent tubes and affecting the measurements or potentially damaging the sensitive electronics of the transducers, the open (land-surface) ends of the transducer vent tubes were placed in vented canisters filled with desiccant. The transducers were calibrated at the time of installation to derive a relation to convert transducer output in millivolts $(\mathrm{mV})$ to depth to water below land surface.

\section{Extensometer Construction and Instrumentation}

The dual-stage, counterweighted pipe extensometer was constructed at the Bayside study site, about $400 \mathrm{ft}$ eastsoutheast of the ASR site. An extensometer, which is used, in this case, to measure the change in distance between the bottom of each borehole and the ground surface for two boreholes, provides a measure of aquifer-system compaction within a specified depth interval of sediments. A detailed description of borehole extensometric methods commonly used by the USGS can be found in Riley (1984). The borehole for the shallow extensometer (EXT2) was drilled to 696 $\mathrm{fbls}$, and the borehole for the deep extensometer (EXT1) was drilled to 1,040 fbls (fig. 3). Inclinometer measurements made during drilling indicated that the boreholes deviated from vertical by less than 1.0 degree. Riley (1984) noted that extensometer boreholes should be vertically aligned to prevent friction between the measuring element and the casing because excessive friction can degrade extensometer measurements.

Construction of the extensometer involved several components (fig. 3). A 6-in.-diameter steel casing was anchored in cement at the bottom of each extensometer borehole. Three and five slip joints were installed along the well casing string in the shallow and deep extensometers, respectively, to allow the casing string to change length. Each slip joint has $30 \mathrm{in}$. of throw, and the bottom joint of each extensometer casing was compressed by $1 \mathrm{ft}$ to allow vertical displacement in either direction. The slip joints were used to minimize skin friction. Negative skin friction (or downdrag) occurs between the casing and sediments adjacent to the borehole and can cause the extensometer instruments to underrecord compaction or expansion by redistributing vertical stresses near the borehole. To further reduce negative skin friction, the annular space between the casing and the borehole was grouted with low-friction bentonite. A 2-in.-diameter steel extensometer pipe (the measuring element), with three 0.25 -in. holes spaced 5-ft apart near the bottom of the pipe, was placed inside each 6-in. casing. The 2-in.-diameter steel extensometer pipe rests on a 0.75 in.-thick, 3.5 -in.-diameter steel plate situated on top of flat cement in each borehole. The bottom of the extensometer pipe is about $980 \mathrm{fbls}$ in EXT1(below the base of the Deep aquifer) and about $598 \mathrm{fbls}$ in EXT2 (above the bottom of the Deep aquifer).

A wood-framed shelter was constructed over the dualstage extensometer. An instrument table (fig. 3) was positioned over both extensometers. The table was mounted on three 4-in.-diameter steel legs that were cemented in holes bored to a depth of $30 \mathrm{fbls}$. To minimize the effect of shallow sediment movement on the extensometer measurements, each table leg was cemented in a 6-in.-PVC casing, which was inside gravel-filled cardboard forms that were placed around the table legs and the 14-in.-diameter extensometer surface casings to decouple them from the concrete pad constructed for the shelter foundation. Because the instrument table legs were anchored $30 \mathrm{fbls}$, the extensometers measure vertical deformation between about $30 \mathrm{fbls}$ and the bottom of the borehole - $696 \mathrm{fbls}$ for EXT2 and 1,040 fbls for EXT1.

The extensometer pipe was supported above ground by a fulcrum assembly consisting of a fulcrum arm positioned on an arm support welded to a half-inch steel plate atop the 14-in. casing, and it was balanced with counterweights. Following the guidelines of Riley (1984), about 80 to 90 percent of the weight of the extensometer pipe was counterbalanced to minimize flexing of the extensometer pipe, which prevents the pipe from having contact with the well casing. The asymmetrical positioning of the fulcrum arm afforded the arm a mechanical advantage of about 10:1, reducing the required counterweights $(1,160$ pounds for the shallow and and 2,900 pounds for the deep extensometers, without using the fulcrum arm) by an order of magnitude.

Vertical deformation (compaction and expansion) of the aquifer system was measured by recording the movement of the instrument table relative to the top of the extensometer pipe by using digital and analog instruments. A Penny and Giles SLS190 linear displacement sensor, with a resolution of about $0.00001 \mathrm{ft}$ and a travel range of $0.41010 \mathrm{ft}$, was the primary instrument for each extensometer. The top of the linear potentiometer was secured to the instrument table, and the bottom was secured to the extensometer pipe. As the instrument table moved relative to the extensometer pipe, the linear potentiometer output a voltage proportional to the displacement. The output voltage was recorded on an electronic data logger inside the shelter.

Analog dial gages also were used to measure vertical deformation. The dial gages were attached to pieces of angled metal affixed to the instrument table. A spring-controlled stem protruding from the bottom of the dial gage rested on a fixed reference surface attached to the extensometer pipe. The stem compressed or expanded as the instrument table moved relative to the fixed reference surface. The analog dial gage can be read to a precision of $0.0001 \mathrm{in}$. The dial-gage readings were not recorded electronically, but were read during each of the site visits, which took place every other month. These readings were used to check linear-displacement sensor performance. 


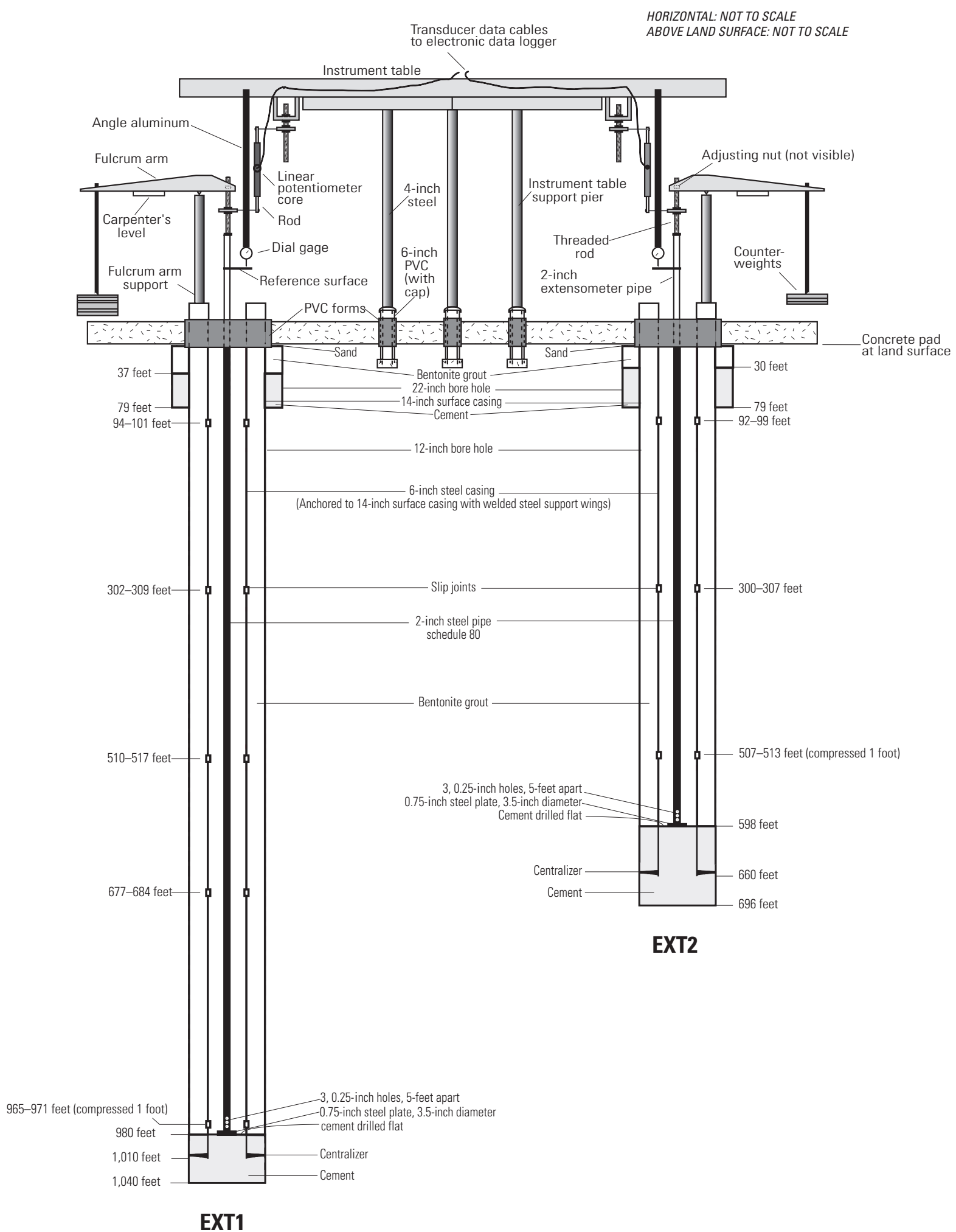

Figure 3. Diagram showing the cConstruction of the dual-stage extensometer at Bayside. 


\section{Lithologic and Geophysical Logging}

Drill cuttings were collected at 5- and 10-ft intervals during drilling by using a number 60 to 120 mesh sieve and were placed in compartmentalized boxes for later detailed description and archiving. The lithology of drill cuttings was initially described in the field, then refined in the office, for grain size and any other noticeable features, such as wood or shell fragments. Particle-size descriptions followed the National Research Council (1947) classification. This classification allows for the correlation of general grain-size terms (such as "sand"), which have size limits determined in millimeters or inches. The cataloged drill cuttings were then compiled and simplified to construct a lithologic summary (fig. 2).

Upon completion of drilling the deepest borehole at each site, a suite of borehole geophysical logs was made in the uncased borehole by the USGS. The logs (fig. 2) generally included spontaneous potential, 16-in. and 64-in. normal resistivity, guard resistivity, natural gamma, and caliper logs. Interpretation of data derived from these logs were used to identify the depths of contacts between hydrogeologic units and to plan the length and location of the piezometer screen intervals for completion of construction of the piezometers in the borehole.

\section{Water-Level and Aquifer-System-Compaction Measurements}

Periodic water-level measurements were taken every other month in the EBAY piezometers by using either calibrated electric tape or steel tape; water levels were measured continuously by General Electric ${ }^{\circledR}$ Druck 10-psi gauged submersible pressure transducers and were recorded at the beginning of each hour by data loggers. The periodic and continuous measurements were compared; differences were attributed to electronic drift in the output signal of the transducers that was not a function of a change of the groundwater level (Rosenberry, 1990). The periodic and continuous groundwater-level data from the transducers were processed and stored in the USGS National Water Information System (NWIS) database. Computer programs in the NWIS database were used to convert the transducer outputs in $\mathrm{mV}$ to values of depth to groundwater in fbls by using an equation derived from the transducer calibration data. A datum correction was applied to the converted data to account for transducer drift. Gaps in the recorded data were caused by transducer failure.

Periodic aquifer-system compaction measurements were made at the EXT1 and EXT2 extensometers by using analog dial gages, and continuous aquifer-system compaction measurements were made hourly by using linear potentiometers and recording data loggers. The periodic and continuous measurements were compared, and the differences were attributed to electronic drift, which was negligible, or to downhole friction, which occurred in EXT1. The continuous aquifer-system compaction data from the linear potentiometers were processed and stored in the NWIS database. Computer programs in the NWIS database were used to convert the linear potentiometer output (in $\mathrm{mV}$ ) to displacement (in ft) by using an equation derived from the linear potentiometer specifications. Datum corrections were applied to the converted data to account for linear potentiometer adjustments. Gaps in the recorded data were caused by disturbances to the extensometers during field-site maintainance visits.

\section{Slug Tests}

Slug tests were performed within the six EBAY piezometers and nine nearby wells between July 30 and August 3, 2007, to estimate hydraulic conductivity of the hydrogeologic units next to the screened zones (fig. 1). The slug tests were done in monitoring wells varying in diameter, depth, screen length, and construction method. For the nine wells not constructed by the USGS, construction information was limited. Key construction information about each well is summarized in table 2, and well construction diagrams for the EBAY piezometers are presented in figure $2 \mathrm{~A}$.

Four different sizes of slugs - two for each well diameter-were used to create the displacement of water in the well. The slugs were constructed of PVC pipe capped at both ends and filled with sand for weight. The slug was connected to parachute cord at one end, which allowed for quick and easy insertion and removal of the slug. The large slug used in the 2-inch-diameter wells measured 1.315 inches in diameter by 63.2 -inches long ( 0.0497 cubic feet, or $\left.\mathrm{ft}^{3}\right)$ and produced $2.42 \mathrm{ft}$ of displacement. The small slug used in the 2-inch-diameter wells measured 1.05 inches in diameter by 61.25 -inches long $\left(0.0307 \mathrm{ft}^{3}\right)$ and produced $1.50 \mathrm{ft}$ of displacement. The large slug used in the 4-inch-diameter wells measured 2.375 inches in diameter by 66.75 -inches long $\left(0.1711 \mathrm{ft}^{3}\right)$ and produced $1.94 \mathrm{ft}$ of displacement. The small slug used in the 4-inch-diameter wells measured 1.66 inches in diameter by 68.5 -inches long $\left(0.0858 \mathrm{ft}^{3}\right)$ and produced $0.98 \mathrm{ft}$ of displacement.

Data for these tests were collected and recorded by using In-Situ ${ }^{\circledR}$ Inc., LevelTroll-500 10-psi- gauged pressure transducers. The transducers were calibrated at the factory prior to being used, and the calibrations were verified before the slug tests were performed. 
Table 2. Well-identification and construction information for slug test and water-quality data collection sites, Alameda County, California.

[Abbreviations: ft, feet; fbls, feet below land surface; in., inches; USGS, U.S. Geological Survey; —, not available]

\begin{tabular}{|c|c|c|c|c|c|c|}
\hline $\begin{array}{c}\text { Well } \\
\text { identification } \\
\text { number }\end{array}$ & $\begin{array}{c}\text { USGS } \\
\text { site } \\
\text { number }\end{array}$ & $\begin{array}{l}\text { Altitude of } \\
\text { land surface } \\
\text { (ft) })^{1}\end{array}$ & $\begin{array}{l}\text { Depth } \\
\text { (fbls) }\end{array}$ & $\begin{array}{c}\text { Top } \\
\text { of screen } \\
\text { (fbls) }\end{array}$ & $\begin{array}{l}\text { Bottom } \\
\text { of screen } \\
\text { (fbls) }\end{array}$ & $\begin{array}{c}\text { Casing } \\
\text { diameter } \\
\text { (in.) }\end{array}$ \\
\hline EBAY1 & 374004122092101 & 7.0 & 1,010 & 990 & 1,010 & 2.32 \\
\hline EBAY2 & 374004122092102 & 7.0 & 860 & 830 & 860 & 1.94 \\
\hline${ }^{2} \mathrm{EBAY} 3$ & 374004122092103 & 7.0 & 640 & 530 & 550 & 1.94 \\
\hline${ }^{2} \mathrm{EBAY} 3$ & 374004122092103 & 7.0 & 640 & 570 & 590 & 1.94 \\
\hline EBAY5 & 374004122092105 & 7.0 & 138 & 128 & 138 & 1.94 \\
\hline EBAY6 & 374004122092106 & 7.0 & 45 & 35 & 45 & 1.94 \\
\hline EBKA1 & 374034122090701 & 15.0 & 325 & 315 & 325 & 1.94 \\
\hline EBKA2 & 374034122090702 & 15.0 & 210 & 200 & 210 & 1.94 \\
\hline EBMY1 & 374111122064601 & 52.0 & 335 & 325 & 335 & 1.94 \\
\hline EBSP2 & 374119122094302 & 5.0 & 360 & 340 & 360 & 1.94 \\
\hline EBSP3 & 374119122094303 & 5.0 & 120 & 100 & 120 & 1.94 \\
\hline MW-FH & 374107122075301 & 34.7 & 540 & 500 & 530 & 1.94 \\
\hline${ }^{2} \mathrm{MW}-1$ & 374005122092502 & 5.9 & 650 & 520 & 550 & 1.94 \\
\hline${ }^{2} \mathrm{MW}-1$ & 374005122092502 & 5.9 & 650 & 570 & 590 & 1.94 \\
\hline${ }^{2} \mathrm{MW}-1$ & 374005122092502 & 5.9 & 650 & 620 & 640 & 1.94 \\
\hline MW-2D & 374005122092202 & 6.1 & 200 & 160 & 190 & 1.94 \\
\hline${ }^{2} \mathrm{OW} 3$ & 374005122092601 & 6.7 & 660 & 525 & 565 & 1.94 \\
\hline${ }^{2} \mathrm{OW} 3$ & 374005122092601 & 6.7 & 660 & 575 & 595 & 1.94 \\
\hline${ }^{2} \mathrm{OW} 3$ & 374005122092601 & 6.7 & 660 & 625 & 655 & 1.94 \\
\hline
\end{tabular}

${ }^{1}$ The altitude of land surface is described in feet above the National Geodetic Vertical Datum (NGVD) 1929.

${ }^{2}$ This piezometer was constructed with 3 separate screened intervals.

Water levels for each well were measured before testing began by using a calibrated electric tape. The transducers were set at depths ranging from 20.0 to $21.4 \mathrm{ft}$ below the water level, and the slug was lowered to approximately $5 \mathrm{ft}$ above the water. Sufficient time, 30 minutes for most wells, was allowed to determine if water levels were static. The data logger was set to record the depth to water every second, and the slug was rapidly lowered into the water. Sufficient time was allowed for recovery of the water level. The slug was then quickly removed. Sufficient time was again allowed for recovery to static levels. This process was repeated four to nine times per well, depending on the recovery conditions. A second slug with a smaller volume was used to complete an additional five tests at each well. 
Computations were performed by using a Microsoft ${ }^{\circledR}$ Excel spreadsheet created by Keith Halford (Halford and Kuniansky, 2002) of the USGS by using methods developed by James Butler of the Kansas Geological Survey (Butler and Garnett, 2000). The following assumptions were made for the computation of the data: the volume of water is injected into, or is discharged from, the well instantaneously, and the well is of finite diameter and fully penetrates the aquifer. The aquifers were assumed to be confined, homogeneous, isotropic, and of uniform thickness. It was assumed also that flow within the aquifer is horizontal and radially symmetric and that the response is evenly distributed over the entire screened interval. Accordingly, for these calculations, the aquifer thickness was assumed to be equal to the length of the screened interval of the monitoring well. For wells containing multiple screened intervals, the bottom of the screen was calculated by adding the effective screen length to the top of the screen; for example, a screened interval of 100-120 ft and 160-180 ft had an effective screened interval of $40 \mathrm{ft}$ and was analyzed as a screen interval of 100-140 ft.

\section{Water Quality}

\section{Sample Collection and Analysis}

Water-quality samples were collected from all 14 piezometers constructed as part of this study. Piezometers are identified by borehole designation, numbered deepest to shallowest, and were sampled during two events. The six piezometers in the EBAY borehole were sampled in June of 2007 by USGS GAMA program personnel. The eight piezometers in the boreholes EBKA, EBMY, and EBSP were sampled in December 2008 by USGS National Water Quality Assessment (NAWQA) program personnel. All samples were collected and processed in accordance with protocols outlined by the USGS NAWQA program (Koterba and others, 1995) and the USGS National Field Manual (U.S. Geological Survey, variously dated).

Piezometers were pumped to purge at least three casing volumes of water from the piezometer (Wilde and others, 2006), except for EBAY1, which had a hydraulic conductivity too low to permit recovery in the time allotted for the sampling event. All piezometers, except the EBKA piezometers, were sampled by using a Grundfos ${ }^{\circledR}$ Redi-Flo2 submersible pump. Because piezometer instrumentation caused diameter restrictions, the EBKA piezometers were sampled by using a Waterra ${ }^{\circledR}$ inertial pumping system. Temperature, dissolved oxygen, $\mathrm{pH}$, and specific conductance were measured by pumping groundwater through a flow-through chamber fitted with a YSI ${ }^{\circledR} 556$ MPS (multiprobe system) multiparameter meter, which was calibrated daily. Turbidity was measured with a Hach M 2100P turbidimeter. Field measurements were recorded at 5-minute intervals for at least 30 minutes to determine parameter stability. Samples were collected after these measurements remained stable for 20 minutes.

Samples collected for nutrients, major and minor ions, and trace elements were analyzed by the USGS National Water Quality Laboratory (NWQL) in Denver, Colorado. The USGS Stable Isotope Laboratory in Reston, Virginia, analyzed samples for isotopic ratios of hydrogen and oxygen in water. Samples for activities of carbon-14 collected prior to November 2008 (EBAY 1-6) were analyzed by the University of Waterloo, Environmental Isotope Lab (CAN-UWIL) and the University of Arizona Accelerator Mass Spectrometry Lab (AZ-UAMSL). Samples for activities of carbon-14 collected after November 2008 were analyzed by the National Ocean Sciences AMS Facility (NOSAMS). The USGS Stable Isotope and Tritium Laboratory in Menlo Park, California, analyzed samples for tritium.

\section{Quality Assurance}

All quality-assurance methods followed protocols outlined by the USGS NAWQA program (Koterba and others, 1995), which are described in the USGS National Field Manual (U.S. Geological Survey, variously dated). A field blank was collected during the December 2008 sampling event to evaluate the potential of contamination in the field. Qualitycontrol samples collected by the GAMA program for the June 2007 sampling are explained in detail by Ray and others (2009).

\section{Core Collection, Processing, and Subsampling}

Results of the cuttings descriptions and geophysical logs from EXT1 (deep extensometer borehole) were used to select intervals to be cored in the other Bayside site boreholes. Core samples, 2.3-in. diameter by 5 -ft long, were taken from two boreholes at Bayside. In total, $284 \mathrm{ft}$ of core was collected during August 2006-274 ft from EBAY (piezometer borehole) and $10 \mathrm{ft}$ from EXT2 (shallow extensometer borehole) - to augment zones of poor core recovery in EBAY (table 3). Additional core was collected in 2007 at the Bayside site from borehole ALC 085 by the USGS Earthquake Hazards Team to augment zones of poor core recovery (20-35 ft below land surface) from the EBAY borehole (Bennett and others, 2009). 
Table 3. Core recovery for each 5-foot interval from the East Bay Bayside Monitoring Site (EBAY) and East Bay Extensometer-2 Monitoring Site (EXT2) boreholes.

[The "shoe" sample is taken from the detachable end of the inner core barrel. As the core is collected, the shoe acts as a drive point by funneling the soil into the core liner. This sample stuck inside the shoe is saved as core material but labeled as "shoe" because it is not in a liner and may be highly disturbed by the process of removing the material from the shoe.]

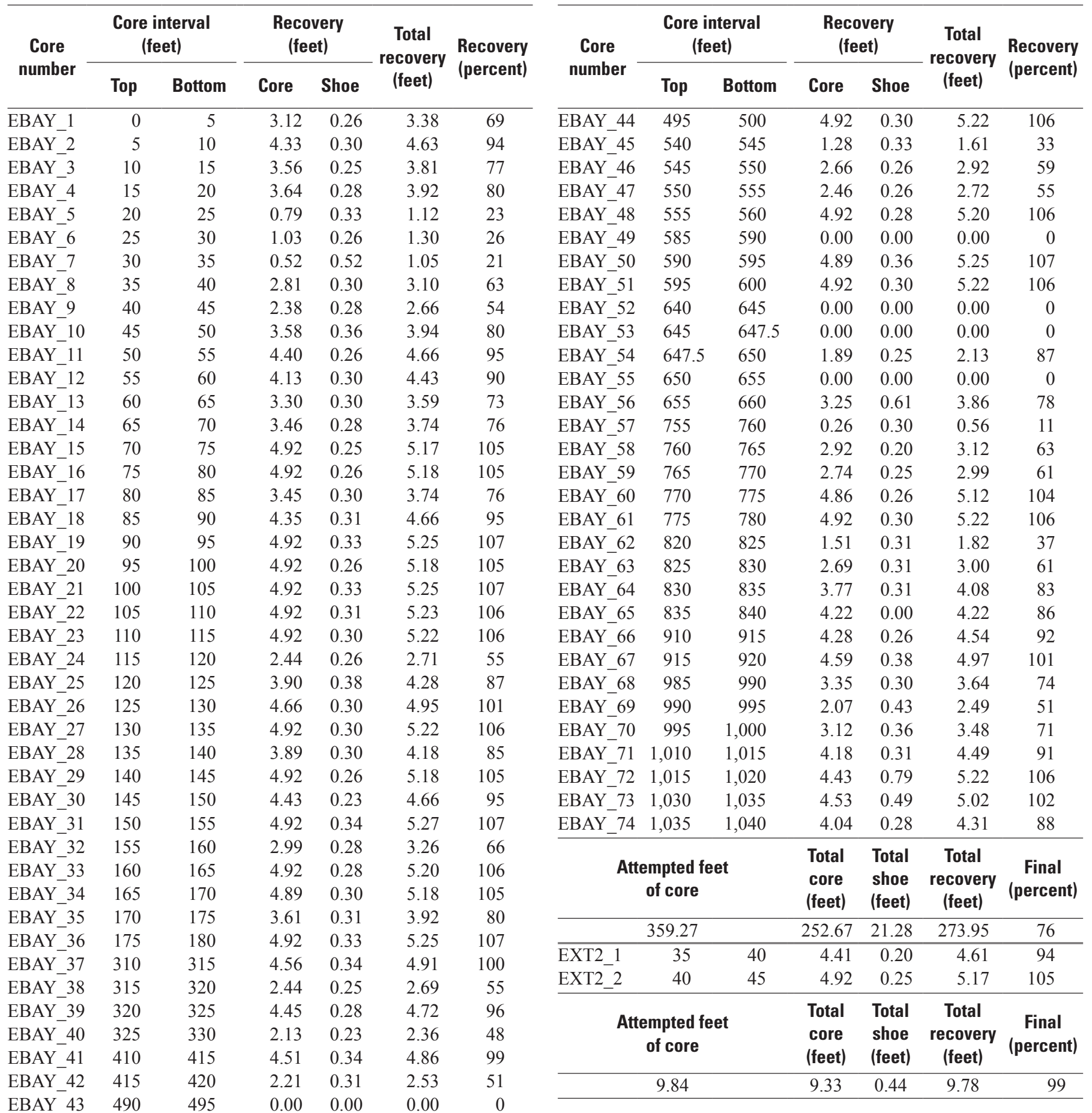


Sediment cores were processed at the USGS labs at Menlo Park, California, between August 8 and September 9, 2006. Between August 8 and 18, 2006, the USGS Heat-FlowStudies Group measured thermal conductivity of core material at three places on each 5-ft-core section. The cores were scanned by using the GEOTEK ${ }^{\mathrm{TM}}$ Multi-Sensor Core Logger (MSCL) system to non-destructively test the whole core for compressional wave velocity, gamma bulk density, magnetic susceptibility, and electrical resistivity, which provided an indication of sediment lithology without disturbing the cores. The compressional wave-velocity sensor measures the compressional wave velocity as a function of distance over time by transmitting an ultrasonic compressional pulse through the core between a piezoelectric transmitter-receiver transducer pair. The gamma bulk-density sensor passes gamma rays through the core sample, which are detected on the other side. The density is determined by measuring the number of gamma photons that pass through the core unattenuated. The magnetic-susceptibility sensor produces an alternating magnetic field, which is influenced by the magnetic susceptibility of the material being analyzed. The resulting changes detected in the oscillator frequency are converted into magnetic-susceptibility values. The electrical-resistivity sensor operates by inducing a high-frequency magnetic field in the core sample from a transmitter coil. A receiver coil measures the resulting electrical currents in the core sample, which are inversely proportional to the resistivity. A more detailed description of the MSCL system sensors can be found on the GEOTEK website (http://www.geotek.co.uk/products/ sensors, accessed September 12, 2012). The MSCL logs were used to select core intervals for physical testing (consolidation and permeability) and absolute-age determination. These cores were split; half of the core was digitally photographed, scanned with the MSCL system, and archived in a 'D' tube, which was capped and taped, at the USGS refrigerated storage facility in Menlo Park, California. USGS staff described sedimentological features in the other half of the core and collected subsamples for the determination of chemical, physical, and mechanical properties, mineralogy, age-dating, and depositional environment. A sedimentological database was created to document the physical description of each of the cores, subsample depths, and MSCL data. A summary of analyses performed on the cores is presented in table 4.

\section{Physical and Mechanical Determinations}

Physical and mechanical charactersitics of the sediment cores were determined in the laboratory to better understand how the aquifer system reacts to applied stress, such as ASR injection. These determinations included estimations of bulk density, porosity, volumetric water content, saturation values, vertical hydraulic conductivity, and consolidation potential.

Bulk-density, porosity, volumetric water-content, and saturation values were calculated by heating the samples in an oven set to a $105^{\circ} \mathrm{C}$. As soon as possible after a core was split, a small, round plug of core was removed and weighed. If a sedimentological change was noted within a length of core, then more than one plug of core was removed to represent each section. These sediment plugs were dried for at least 18 hours in a drying oven at $102-107^{\circ} \mathrm{C}$. After drying, the plugs were weighed again, and moisture content by mass was calculated as the amount of mass loss due to evaporation. A relative-humidity oven was used to estimate residual water content, effective porosity, and effective saturation of these sediment cores. Each method was performed in accordance with Yucca Mountain Project Branch (YMPB-USGS-HP-229, R3-M3) protocols.

Vertical hydraulic-conductivity values were determined by USGS scientists in the California Water Science Center in Sacramento for 20 selected cores by using measurements from a Tri-Flex 2 Permeability Test System (ELE International, Loveland, Colo.) in accordance with ASTM Standard D5084 (American Society for Testing and Materials, 2003). Saturated vertical hydraulic conductivity values were corrected to $20^{\circ} \mathrm{C}$. Specific water chemistry for use in the vertical hydraulicconductivity measurements was synthesized on the basis of the results of the pore-water chemistry analyses to mimic chemical conditions in the aquifer system. Changes in water chemistry could cause expansion and contraction of clays, which would affect the hydraulic conductivity (Lambe and Whitman, 1969; Hille, 1980). The 20 pore-water chemical determinations were compared and categorized into five water types. Each core sample was assigned a water type according to depth similarity between the pore-water determination and core sample. Synthetic water flowed through core samples under gradients ranging from 21 to 400 kilopascal $(\mathrm{kPa})$. Most samples were tested twice by using two different gradients, but three samples (EBAY_2, EXT2_2, and EBAY_60) were analyzed twice with the same test gradient.

A computerized and fully automated, uniaxial load frame (Geocomp Corporation, Boxborough, Mass.) was used to perform incremental-consolidation (non-back-pressured) tests by using the traditional incremental-loading method of Casagrande (1936). Samples were provided with doubledrainage within a water-filled cell. The breaks in slope in the consolidation curves generated were interpreted, in part, by using the methods of Schmertmann (1954), which primarily attempt to overcome the effects of sample disturbance. Results from the consolidation tests were used to calculate elastic and inelastic specific storages. These calculations were derived by Sneed (2001). 
Table 4. Summary of analyses conducted on sediment cores from the East Bay Bayside Monitoring Site (EBAY) and East Bay Extensometer-2 Monitoring Site (EXT2) boreholes.

[Abbreviations: ICP-MS, inductively coupled plasma-mass spectroscopy; INAA, instrumental neutron activation by abbreviated count; IRSL, infrared stimulated luminescence; OSL, optically stimulated luminescence; SEM-EDS, scanning electron microscopy-energy dispersive spectroscopy; XRD, X-ray diffraction; - , no analysis]

\begin{tabular}{|c|c|c|c|c|c|c|c|c|c|c|c|}
\hline & & & & & $\begin{array}{l}\text { lysis } \\
\text { le num }\end{array}$ & & & & & & \\
\hline $\begin{array}{c}\text { Core } \\
\text { number }\end{array}$ & 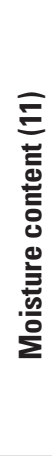 & 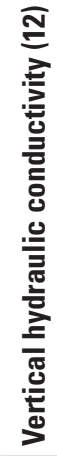 & 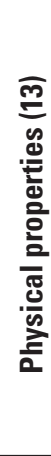 & 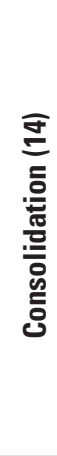 & 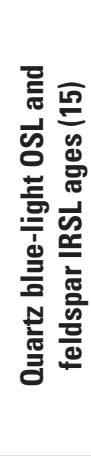 & 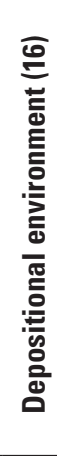 & 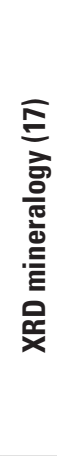 & 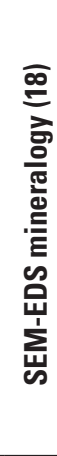 & 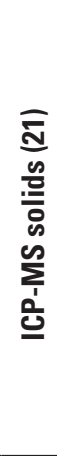 & 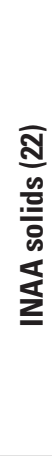 & 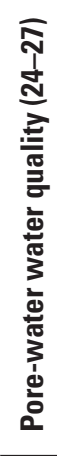 \\
\hline$\overline{\text { EXT2_1 }}$ & - & - & - & - & $\mathrm{x}$ & - & - & - & - & $\mathrm{x}$ & - \\
\hline EXT2_2 & - & $\mathrm{x}$ & $\mathrm{x}$ & - & - & - & - & - & - & - & - \\
\hline EBAY_1 & $\mathrm{x}$ & - & - & - & - & - & - & - & - & - & - \\
\hline EBAY_2 & $\mathrm{x}$ & $\mathrm{x}$ & $\mathrm{x}$ & $\mathrm{x}$ & - & $\mathrm{x}$ & - & - & - & - & $\mathrm{x}$ \\
\hline EBAY_3 & $\mathrm{x}$ & - & - & - & - & $\mathrm{x}$ & - & - & - & - & - \\
\hline EBAY_4 & $\mathrm{x}$ & - & - & - & - & $\mathrm{x}$ & - & - & - & - & - \\
\hline EBAY_6 & $\mathrm{x}$ & - & - & - & - & - & - & - & - & - & - \\
\hline EBAY_8 & - & - & - & - & $\mathrm{x}$ & - & - & - & - & $\mathrm{x}$ & - \\
\hline EBAY_9 & - & - & - & - & $\mathrm{x}$ & - & - & - & - & $\mathrm{x}$ & - \\
\hline EBAY_10 & - & - & - & - & $\mathrm{x}$ & $\mathrm{x}$ & $\mathrm{x}$ & $\mathrm{x}$ & $\mathrm{x}$ & $\mathrm{x}$ & - \\
\hline EBAY_11 & $\mathrm{x}$ & - & - & - & - & - & - & - & - & - & - \\
\hline EBAY_12 & $\mathrm{x}$ & $\mathrm{x}$ & $\mathrm{x}$ & $\mathrm{x}$ & - & $\mathrm{x}$ & - & - & - & - & $\mathrm{x}$ \\
\hline EBAY_13 & $\mathrm{x}$ & - & - & - & - & - & - & - & - & - & - \\
\hline EBAY_14 & $\mathrm{x}$ & - & - & - & - & - & - & - & - & - & $\mathrm{x}$ \\
\hline EBAY_15 & $\mathrm{x}$ & $\mathrm{x}$ & $\mathrm{x}$ & $\mathrm{x}$ & - & $\mathrm{x}$ & - & - & - & - & - \\
\hline EBAY_16 & $\mathrm{x}$ & - & - & - & - & $\mathrm{x}$ & - & - & - & - & - \\
\hline EBAY_17 & $\mathrm{x}$ & - & - & - & $\mathrm{x}$ & $\mathrm{x}$ & $\mathrm{x}$ & $\mathrm{x}$ & $\mathrm{x}$ & $\mathrm{x}$ & - \\
\hline EBAY_18 & - & $\mathrm{x}$ & $\mathrm{x}$ & $\mathrm{x}$ & - & $\mathrm{x}$ & - & - & - & - & - \\
\hline EBAY_19 & $\mathrm{x}$ & - & - & - & - & $\mathrm{x}$ & - & - & - & - & $\mathrm{x}$ \\
\hline EBAY_20 & $\mathrm{x}$ & $\mathrm{x}$ & $\mathrm{x}$ & $\mathrm{x}$ & - & - & - & - & - & - & - \\
\hline EBAY_21 & $\mathrm{x}$ & - & - & - & - & - & - & - & - & - & - \\
\hline EBAY_22 & $\mathrm{x}$ & $\mathrm{x}$ & $\mathrm{x}$ & $\mathrm{x}$ & - & $\mathrm{x}$ & - & - & - & - & - \\
\hline EBAY_23 & $\mathrm{x}$ & - & - & - & - & - & - & - & - & - & - \\
\hline EBAY_24 & $\mathrm{x}$ & - & - & - & - & - & - & - & - & - & - \\
\hline EBAY_25 & $\mathrm{x}$ & - & - & - & $\mathrm{x}$ & - & $\mathrm{x}$ & $\mathrm{x}$ & $\mathrm{x}$ & $\mathrm{x}$ & - \\
\hline EBAY_26 & $\mathrm{x}$ & - & - & - & - & $\mathrm{x}$ & - & - & - & - & - \\
\hline EBAY_27 & - & - & - & - & - & $\mathrm{x}$ & - & - & - & - & - \\
\hline EBAY_28 & $\mathrm{x}$ & $\mathrm{x}$ & $\mathrm{x}$ & $\mathrm{x}$ & - & $\mathrm{x}$ & - & - & - & - & - \\
\hline EBAY_29 & $\mathrm{x}$ & $\mathrm{x}$ & $\mathrm{x}$ & $\mathrm{x}$ & - & $\mathrm{x}$ & $\mathrm{x}$ & $\mathrm{x}$ & $\mathrm{x}$ & - & \\
\hline EBAY_30 & $\mathrm{x}$ & - & - & - & - & - & - & - & - & - & $\mathrm{x}$ \\
\hline EBAY_31 & $\mathrm{x}$ & - & - & - & - & - & - & - & - & - & - \\
\hline
\end{tabular}

\begin{tabular}{|c|c|c|c|c|c|c|c|c|c|c|c|}
\hline \multicolumn{12}{|c|}{$\begin{array}{l}\text { Analysis type } \\
\text { (table number) }\end{array}$} \\
\hline $\begin{array}{c}\text { Core } \\
\text { number }\end{array}$ & 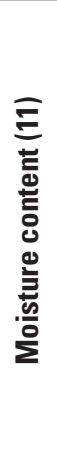 & 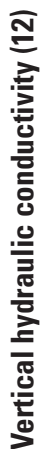 & 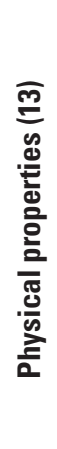 & 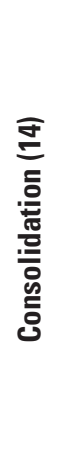 & 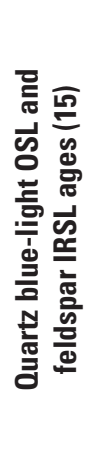 & 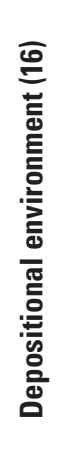 & 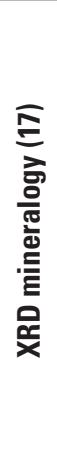 & 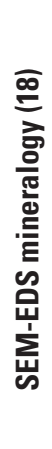 & 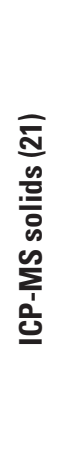 & 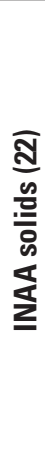 & 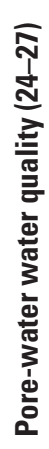 \\
\hline
\end{tabular}

EBAY $32 \mathrm{x}----\infty---$

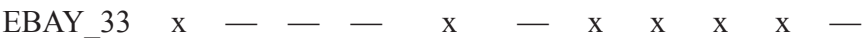
EBAY_34 $\mathrm{x}--------$

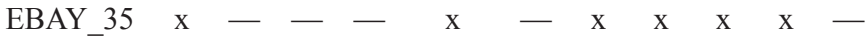
EBAY_36 $\quad \mathrm{x} \quad \mathrm{x} \quad \mathrm{x} \quad \mathrm{x} \quad-\quad \mathrm{x} \quad-\quad-\quad--$

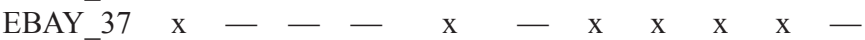
EBAY 39 $\mathrm{x} \quad \mathrm{x} \quad \mathrm{x} \quad \mathrm{x} \quad-\quad-\quad-\quad-\quad-\mathrm{x}$ EBAY_40 $\mathrm{x}-\mathrm{x}-\mathrm{x}-\mathrm{x}--$ $\begin{array}{llllllllllll}\text { EBAY_41 } & \mathrm{x} & \mathrm{x} & \mathrm{x} & \mathrm{x} & - & \mathrm{x} & \mathrm{x} & \mathrm{x} & \mathrm{x} & - & \mathrm{x}\end{array}$ $\begin{array}{llllllllllll}\text { EBAY_44 } & \mathrm{x} & \mathrm{x} & \mathrm{x} & \mathrm{x} & - & \mathrm{x} & \mathrm{x} & \mathrm{x} & \mathrm{x} & - & \mathrm{x}\end{array}$ EBAY_46 - $-\quad-\quad-\quad-\quad \mathrm{x} \quad \mathrm{x} \quad \mathrm{x}-$ EBAY_48 $\quad \mathrm{x} \quad \mathrm{x} \quad \mathrm{x} \quad \mathrm{x} \quad \begin{array}{llllllll} & \mathrm{x} & \mathrm{x} & \mathrm{x} & \mathrm{x} & - & \mathrm{x}\end{array}$ EBAY_50 $\quad \mathrm{x} \quad \mathrm{x} \quad \mathrm{x} \quad \mathrm{x} \quad \begin{array}{llllllll}- & \mathrm{x} & \mathrm{x} & \mathrm{x} & \mathrm{x} & - & -\end{array}$

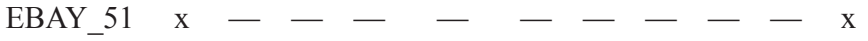
EBAY_54 $\mathrm{x}---\mathrm{x}-\mathrm{x}-\mathrm{x}-\mathrm{x}$ EBAY_56 $\mathrm{x}---\mathrm{x}-\mathrm{x}-\mathrm{x}-\mathrm{x}$ EBAY_58 $\mathrm{x}---\mathrm{x}-\mathrm{x}-\mathrm{x}-\mathrm{x}$

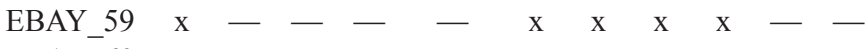
EBAY_60 $\quad \mathrm{x} \quad \mathrm{x} \quad \mathrm{x} \quad-\quad-\quad-\quad \begin{array}{lllllll} & \mathrm{x} & \mathrm{x} & \mathrm{x} & - & \mathrm{x}\end{array}$ EBAY_61 $\mathrm{x}--------$ EBAY_62 - - - - - - - - $-\mathrm{x}$ EBAY_63 $\quad \mathrm{x} \quad \mathrm{x} \quad \mathrm{x}--\quad---$ EBAY_64 $\mathrm{x}---\mathrm{x}---$ EBAY_65 - - - - - - $-\frac{1}{\mathrm{x}} \mathrm{x}-$ EBAY_66 $\mathrm{x}-\mathrm{x}-\mathrm{x}-\mathrm{x}-\mathrm{x}-\mathrm{x}$

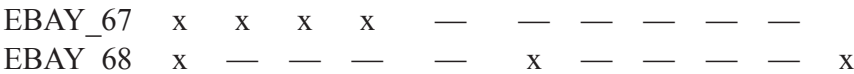

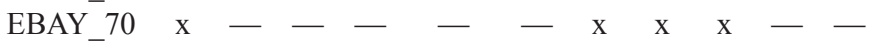

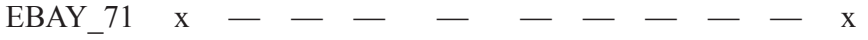
EBAY_72 $\mathrm{x} \quad \mathrm{x} \quad \mathrm{x} \quad \mathrm{x} \quad-\quad \mathrm{x}--$ EBAY_73 $\quad \mathrm{x} \quad \mathrm{x} \quad \mathrm{x} \quad-\quad-\quad \begin{array}{llllllll} & - & \mathrm{x} & \mathrm{x} & \mathrm{x} & - & -\end{array}$ EBAY_74 $\mathrm{x}-\mathrm{x}-\mathrm{x}-\mathrm{x}-\mathrm{x}$ 


\section{Age Determinations}

Most minerals react to ionizing radiation by essentially gaining energy at the electron level, which accumulates through time if that energy is not released (as light) by some outside stimuli (sunlight or intense heat over $200^{\circ} \mathrm{C}$ ). Thus, sediment grains can record their exposure history to ionizing radiation, which can then be "read" in the laboratory and used much like a clock. This procedure is referred to as luminescence geochronology (Aitken, 1998), the goal of which is to establish the timing of the burial of mineral grains in sedimentary deposits. In terrestrial environments, exposure to sunlight during sediment transport resets the clock, which is why a luminescence age is considered a burial age. In the laboratory, the sediment sample is stimulated to emit light by exposing it to light of specific wavelengths in prescribed manners. The intensity of emitted light measured in the laboratory is proportional to the trapped charge population, which is proportional to the total absorbed radiation dose that the sedimentary deposit experienced, and that relation is proportional to the time elapsed since burial (Murray and others, 1995; Olley and others, 1998; Galbraith and others, 1999; Lepper, 2001; Lepper and McKeever, 2002).

Quartz blue-light optically stimulated luminescence (OSL) and feldspar infrared-stimulated luminescence (IRSL) methods were applied to nine core samples to determine deposition or burial ages (table 4). The quartz blue-light OSL method was chosen as the preferred method of age determination, but was not applicable to the two deepest, oldest samples; therefore, these two samples were analyzed by using only the feldspar IRSL method. Three of the seven samples analyzed by using quartz blue-light OSL were also analyzed by using the feldspar IRSL method.

\section{Determination of Depositional Environment}

Cores were inspected for the presence of foraminifera and diatom fossils to establish the depositional environment and age. Thirty-one 4-centimeter $(\mathrm{cm})$ long sections from thirty sediment core samples were analyzed for foraminifera (table 4). These sediment samples were wet-sieved through nested 63-micrometer $(\mu \mathrm{m}), 150-\mu \mathrm{m}$, and 1.0-millimeter $(\mathrm{mm})$ screens to segregate the size fractions. Sediment remaining on the screens was transferred to filter paper and air dried. Foraminifera were extracted from the greater than $63-\mu \mathrm{m}$ fraction. Samples containing abundant benthic foraminifera were split with the aid of a microsplitter into an aliquot containing at least 300 specimens, which were then picked and identified. Specimens from samples containing very rare foraminifera or other biological constituents were removed from the sediment and placed on faunal slides for archival purposes. The foraminiferal slides and residues were filed at the U.S. Geological Survey, Menlo Park, California. One sample was floated with sodium polytungstate to concentrate the foraminifera before picking.

Relative foraminiferal species abundances of benthic taxa for the two samples with more than 300 foraminifera were computed by using a sum of total benthic foraminifera for that sample. The remaining samples were considered to be statistically invalid, and the species therein were listed only as present.

Four samples, 1-cm in length, were processed for diatom analysis by using hydrogen peroxide, hydrochloric acid, and nitric acid to remove carbonate and organic matter, and sodium pyrophosphate to deflocculate the remaining clay (Battarbee, 1986). Approximately 50 microliters $(\mu \mathrm{l})$ of the resulting suspension was dried on a 22 - by $30-\mathrm{mm}$ coverslip and permanently mounted by using Naphrax ${ }^{\circledR}$. At least 300 frustules were enumerated by following the method of Schrader and Gersonde (1978) and using an Olympus BH-2 microscope at magnifications of 500X or 1,000X. Diatom identification was based on Lowe (1974), Gasse (1986), Krammer and Lange-Bertalot (1986, 1988, 1991a, 1991b), Lange-Bertalot and Krammer (1987, 1989), Cumming and others (1995), Round and Bukhtiyarova (1996), Krammer (1997a, 1997b, 2000, 2002), and Lange-Bertalot (2001).

\section{Mineralogy of Cores}

The mineralogical composition of 16 core samples was determined by X-ray diffraction (XRD; table 4). The XRD method of analysis involves a focused X-ray beam directed at a pulverized mineral. Components of the beam are transmitted through the sample then absorbed, refracted and scattered, and diffracted. Each mineral lattice produces a distinct pattern when an X-ray beam is transmitted through it. The mineralogy of the cores was determined to establish a chemical baseline for better understanding of the potential chemical reactions that could occur between ASR water and the substrate.

Scanning electron microscopy (SEM) and energy dispersive spectroscopy (EDS) were used to analyze 17 samples to (1) identify any secondary minerals, (2) determine the relative abundance of secondary precipitates from the detrital material, (3) determine the presence or absence of organic carbon, (4) determine and document the presence or absence of ferric oxyhydroxide coatings on mineral grains, (5) determine the occurrence of clay minerals, and (6) characterize the morphology of the sediment (table 4).

Three preparations were made for each sample: (1) a bulk sample was placed on an SEM stub to determine the relationship of the secondary mineral precipitate to the detrital grains, (2) a carbon-coated grain mount was made to determine the area fraction of each phase, and (3) a goldcoated grain mount was made to determine the area fraction of organic material. 
Bulk samples were placed on a SEM sample stub and coated with carbon for conductivity. Approximately 0.2 grams (g) of ground sample was placed in approximately 1 milliliter $(\mathrm{mL})$ of isopropanol and shaken to disperse the particles. A $20-\mu 1$ aliquot was taken from the top, middle, and bottom of the mixture, and these were filtered onto a gold coated polycarbonate filter by using a Millipore ${ }^{\circledR}$ setup. The loaded filters were gold coated in preparation for determination of organic content and grain-size analysis.

Samples were analyzed by using a JEOL 5800LV scanning electron microscope operated at 15 kilovolts $(\mathrm{kV})$ and 0.5 to 1.0 nanoamp (nA) beam current. Representative areas of the unground bulk samples were analyzed to determine mineralogy, particle morphology, and possible porefilling minerals. Backscattered electron imaging was used to search for higher average atomic-number accessory minerals, such as apatite, zircon, and sphene and iron oxide coatings.

Binary backscattered images of the grain mounts were thresholded so that the grains were black and the background filter was white. Automated size analyses were acquired with the Noran System Six Feature Sizing software. Grain-size data were then acquired until over 100 particles were analyzed.

\section{Elemental Composition of Cores}

The elemental composition of 17 core samples extracted from between 48 and 1,034 fbls was determined by using inductively coupled plasma-mass spectroscopy (ICP-MS solids; table 4). This method uses a high-temperature inductively coupled plasma source to convert the atoms into ions, which are then separated and detected by the mass spectrometer (Wolf, 2005; Garbarino and others, 2006).

Instrumental neutron activation by abbreviated count (INAA) also was used to determine the elemental composition of nine core samples extracted from between 37 and $312 \mathrm{fbls}$ (table 4). This is a non-destructive, highly precise, and accurate analytical technique capable of determining up to 48 elements in almost all types of sample matrices. The INAA procedure involves irradiating the samples and appropriate standard reference materials with neutrons in the USGS TRIGA (Training, Research, Isotopes, General Atomics) reactor to produce unstable radioactive nuclides. Many of these radionuclides emit gamma rays with characteristic energies that can be measured by utilizing high-resolution semiconductor detectors (Budahn and Wandless, 1996). The rate at which gamma rays are emitted from an element in the sample is directly proportional to its concentration. Samples as small as 1 milligram $(\mathrm{mg})$ can be quantitatively measured by INAA. Detection limits are in the parts per million to parts per billion range depending on the element and sample matrix (http://geology.usgs.gov/usgs/capabilities/chema/inst_ neutron_anal.shtml\#tech; accessed April 15, 2009).

\section{Pore-Water Chemistry}

Twenty pore-water samples were collected from nineteen sections of core from sediment cores take from the EBAY site (table 4). Two of the samples were collected from different depths of the EBAY_2 core to assess variation within a single core. The pore water was extracted by using a hydraulic press and stainless steel capsule system, as described by Manheim and others (1994). A section of core was taken from one half of each of the 19 sections of split-core. The pore water was extracted by gradually applying $3,000-8,000 \mathrm{psi}$ of pressure to approximately $50 \mathrm{~g}$ of sediment from the core in the capsule system; $2-11 \mathrm{~mL}$ of pore water was collected by syringe and filtered through a $0.45-\mathrm{mm}$ polyethersulfone disk filter. Salinity (as percent sodium chloride) and $\mathrm{pH}$ were measured, and then the samples were prepared for the analysis of major ions, trace metals, stable-isotope ratios of hydrogen and oxygen in water, dissolved inorganic carbon (DIC), and alkalinity.

The USGS California Water Science Center WaterQuality Laboratory in San Diego analyzed the samples for the following dissolved anions: chloride, nitrite, bromide, nitrate, orthophosphate, and sulfate. Samples were analyzed by using a non-suppressed ion-chromatographic method (Waters Corporation, 1992), which was adapted for smallvolume, complex-matrix samples, or both (Michael Land, U.S. Geological Survey, written commun., 2009).

Cation and trace-element concentrations were determined by collision/reaction cell inductively coupled plasma-mass spectrometry (cICP-MS) at the USGS National Water Quality Laboratory (NWQL) in Denver, Colorado (Garbarino and others, 2006).

Samples for DIC were analyzed at the USGS California Water Science Center Water-Quality Laboratory in Sacramento. Samples were diluted, and DIC was measured by using a Shimadzu TOC 5000A total organic carbon analyzer. Alkalinity was calculated from DIC, given $\mathrm{pH}$, partial pressure (or the concentration of carbon dioxide in the atmosphere), and the three equilibrium constants for the carbonate system. This calculation assumes that the samples and, therefore, the aquifer are in equilibrium with atmospheric carbon dioxide (Miranda Fram, U.S. Geological Survey, written commun., 2006).

Samples were analyzed for stable-isotope ratios of hydrogen and oxygen in water by gaseous hydrogen and carbon dioxide-water equilibration and stable-isotope mass spectrometry (Coplen and others, 1991) at the USGS Stable Isotope Laboratory in Reston, Virginia.

In addition, 53 cores were sampled for percent-water content. These samples were cut from the split core, weighed, then placed in a drying oven for 18-130 hours. After drying, samples were weighed again, and the percent-water content calculated. This analysis was done at the time the core was processed at the USGS labs in Menlo Park, California. 


\section{Results}

\section{Lithologic and Geophysical Logs}

The lithologic and geophysical logs from the Bayside boreholes indicated unconsolidated to partly consolidated continental and marine alluvial deposits consisting mostly of silt and clay, with the exception of three coarse-sand and gravel beds totaling nearly $98 \mathrm{ft}$ between 508 and $650 \mathrm{fbls}$ (figs. 2A, $B$, and $C$ ). Shear-wave borehole velocity log values, measured at the EBAY site, ranged from 686 feet per second (ft/s), in the upper $100 \mathrm{ft}$, to $906 \mathrm{ft} / \mathrm{s}$, in the upper $330 \mathrm{ft}$, which is about $656 \mathrm{ft} / \mathrm{s}$ slower than values reported for several 1,000-ft-deep boreholes in the Santa Clara Valley (Brocher and others, 2007). The USGS Earthquake Hazards Program designates shear-wave velocities in the upper $100 \mathrm{ft}$ from 656 to 1,148 ft/s as class D (stiff soil) on a scale from A $(4,921 \mathrm{ft} / \mathrm{s})$ to $\mathrm{E}$ (less than $656 \mathrm{ft} / \mathrm{s})$, where shaking is amplified in low-velocity soil and rock types (U.S. Geological Survey, 2012). Boreholes in the Santa Clara Valley penetrated coarser sediments than the clay and silt that were penetrated at the Bayside Site (Brocher and others, 2007). In addition, the shear-wave velocities were slightly slower than predicted by empirical relations between the shear-wave velocity of $\mathrm{P}$ waves $\left(\mathrm{V}_{\mathrm{p}}\right)$ and of $\mathrm{S}$ waves $\left(\mathrm{V}_{\mathrm{s}}\right.$; Castagna and others, 1985). The pronounced seismic-velocity highs at 541,571 , and $633 \mathrm{fbls}$ corresponded to several-feet-thick stringers of coarse sand and gravel. These stringers produce strong, coherent seismic reflectors traceable in nearby seismic-reflection lines at least 1.2 miles (mi) away from the borehole (Catchings and others, 2006). The seismic cone-penetration test (SCPT), performed at the ALCO85 borehole, included determinations of stratification, soil type, shear-wave velocity, density, consistency, penetration resistance, grain size, strength, plasticity, and liquidity, which are described in detail in Bennett and others (2009). According to their study, two stratigraphic intervals, the Holocene bay mud (3.3-11.5 ft) and an interval referred to as the sensitive zone (26.2-28.9 ft), stood out in this 35 -ft boring. Similarities between these intervals included relatively high values of water content and liquidity index, as well as low values for shear-wave velocities and friction. Grain size and stratigraphic sequence distinguish these intervals from each other. The Holocene bay mud has an average median grain size of $0.005 \mathrm{~mm}$, with an average of 3 -percent sand, and the sensitive zone has an average median grain size of $0.030 \mathrm{~mm}$, with an average of 24-percent sand (Bennet and others, 2009). The Holocene bay mud has a fining-upward stratigraphic sequence, and the sensitive zone has a coarsening-upward stratigraphic sequence (Bennet and others, 2009).

Soil-index properties can be used to determine if a soil is susceptible to liquefaction. Bennett and others (2009) identified two intervals, the sensitive zone at 26-ft deep and the dense sand between 33 and 43-ft deep, as having a low liquefaction potential. A more detailed analysis of liquefaction potential is described in their report.

The lithologic and geophysical logs from the EBMY borehole indicated unconsolidated to partly consolidated continental and marine alluvial deposits consisting mostly of silt and clay (fig. 2D). Mudstone was encountered at about 410 fbls.

The lithologic and geophysical logs from the EBKA borehole indicated unconsolidated to partly consolidated continental and marine alluvial deposits consisting mostly of silt and clay, with the exception of two depth intervals of silty sand, at 160-220 fbls and 310-330 fbls, and one depth interval of gravelly sand, at 50-60 fbls (fig. $2 E$ ).

The lithologic and geophysical logs from the EBSP borehole indicated unconsolidated to partly consolidated continental and marine alluvial deposits consisting of clay, silt, and sand (fig. 2F).

\section{Water Levels and Aquifer-System Compaction}

At Bayside, periodic and continuous water-level and aquifer-system-compaction measurements were made beginning in April 2008 and July 2008, respectively (figs. 4A, $B)$. Continuous barometric pressure and air temperature also were measured beginning in July 2008 at Bayside (fig. 4C). Water-level differences in piezometers EBAY2 through EBAY6 showed decreasing hydraulic head with decreasing depth, except for EBAY5, which exhibited the highest hydraulic head (fig. 4A).

The water-level data showed that all of the piezometers fluctuate diurnally. The diurnal response of the piezometers is caused, in part, by pressure changes induced by tides in the San Francisco Bay - the shoreline is only about 1,500 ft from the Bayside site (fig. 1). EBAY3 had the largest magnitude of response; EBAY6 exhibited the smallest response; the other three piezometers exhibited intermediate responses to tide cycles (fig. 4A).

The water-level data showed that some of the water levels in the piezometers fluctuate seasonally. EBAY2 did not exhibit water-level fluctuations at seasonal frequencies, but, instead, showed water level rising at a fairly constant rate for the period of record (fig. 4A). EBAY3 and EBAY4 exhibited water-level fluctuations at seasonal frequencies. Water levels were higher in the winter and spring, with the highest levels in March 2009, and water levels were lower in the summer and fall, with the lowest water levels in September 2008. Water levels in EBAY3 ranged from about 7.7 to $13.8 \mathrm{fbls}$, whereas water levels in EBAY4 ranged from about 6.5 to 10.3 fbls. Similar to EBAY3 and EBAY4, water levels in EBAY5 were higher in the winter and spring and lower in the summer and fall; EBAY5 water levels ranged from about 0.3 to $1.7 \mathrm{fbls}$. Seasonal water-level highs and lows in EBAY5 were in April and October-2 to 3 weeks after EBAY3 and EBAY4 reached their respective maxima and minima. 
$\boldsymbol{A}$
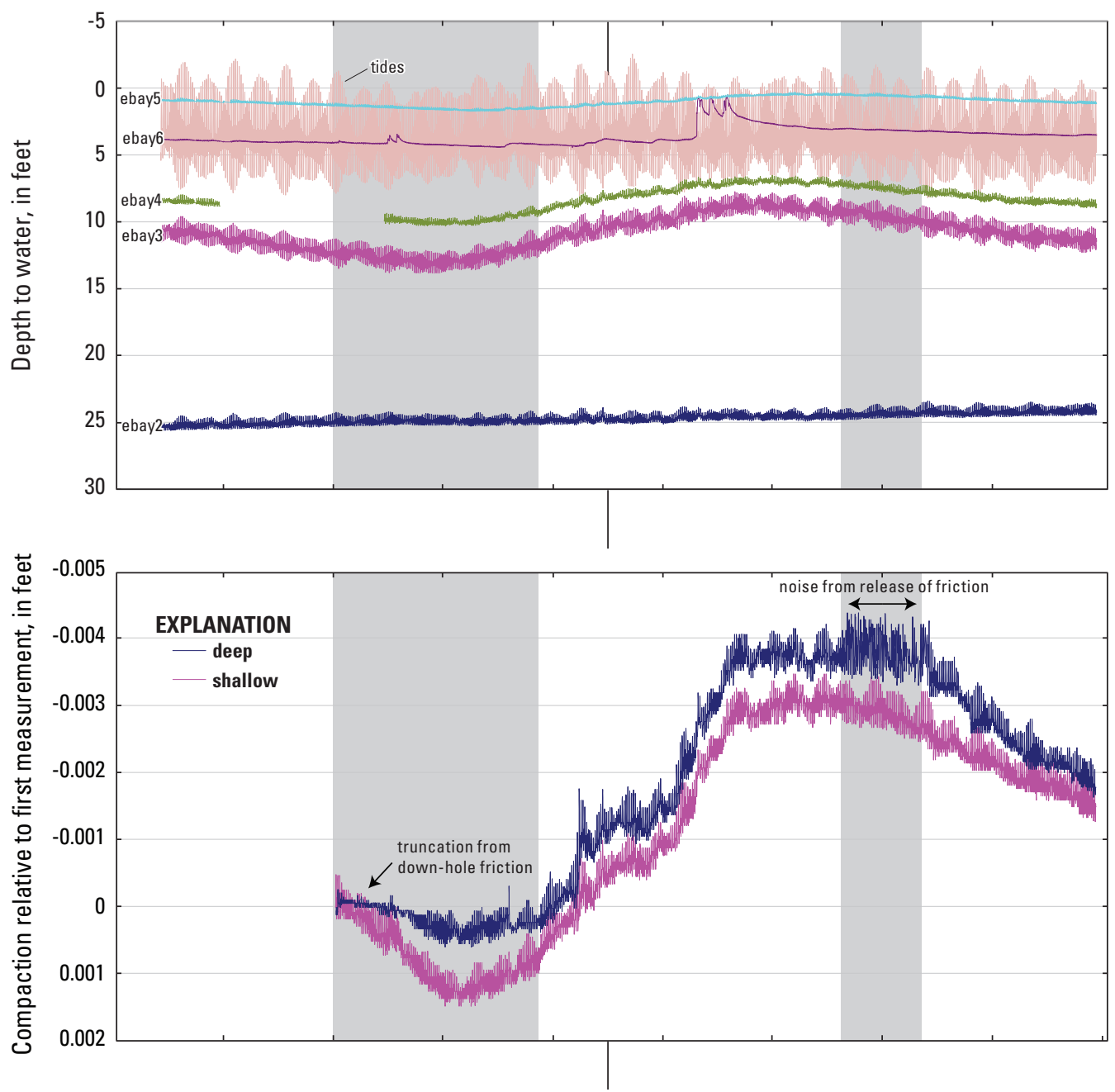

C

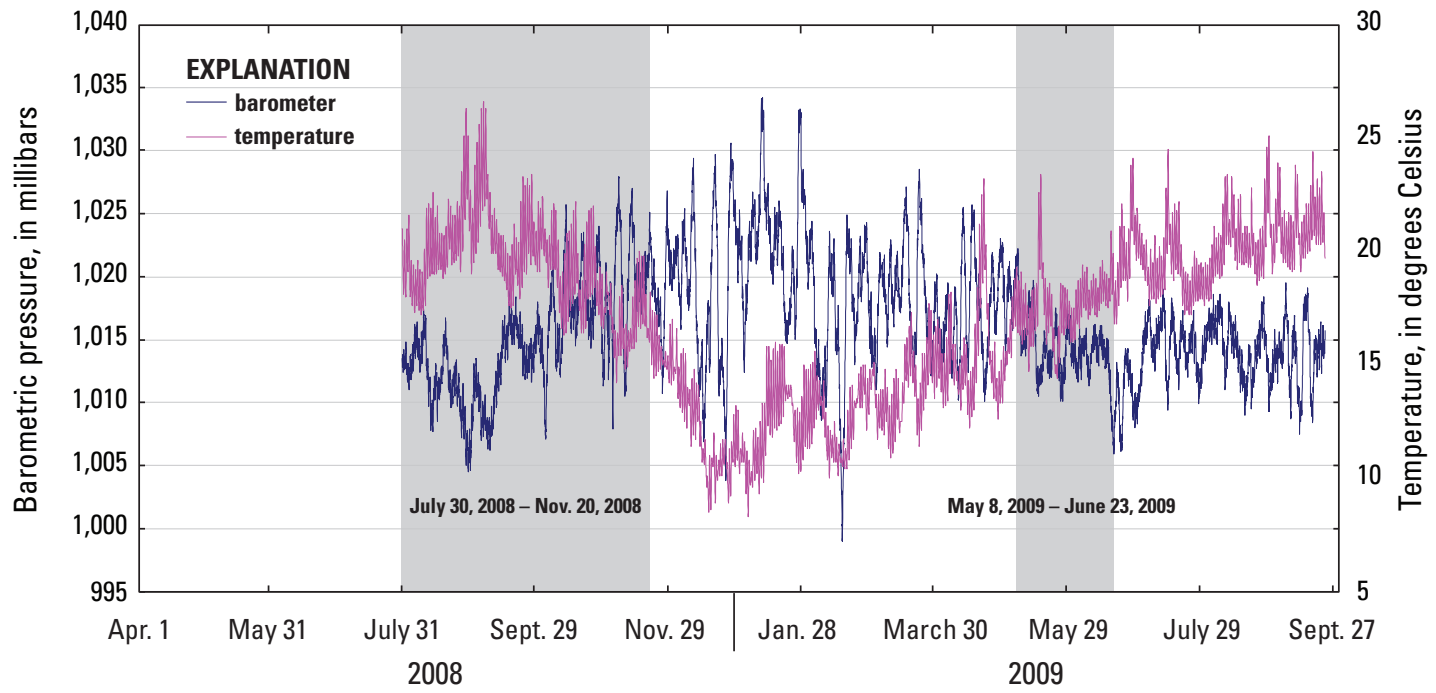

Figure 4. Graphs showing A, Periodic and continuous water levels in East Bay Bayside Monitoring site (EBAY) piezometers, including nearby tide cycles. $B$, Aquifer-system compaction measurements in Bayside extensometers, grey areas indicated periods of friction. $C$, Surface barometric pressure and shelter temperature for Bayside extensometers. 
EBAY6 did not exhibit a seasonal water-level fluctuation but, instead, showed a general monotonic decline periodically interrupted by quickly rising water levels, which corresponded to rainfall events. EBAY6 responded with a water-level rise to pile-driving during construction in August and September 2008 at the neighboring water treatment plant. In February 2009 , large, abrupt water-level rises were caused by a series of rainfall events that caused water to flood the subterranean piezometer housing vault and EBAY6, which had the shortest distance from the bottom of the vault to the top of the 2-in. casing of the six piezometers in the vault. The distance was extended to reduce potential for water to enter the casing in EBAY6 during future rainfall events.

The aquifer-system compaction data for both the deep and shallow extensometers showed seasonal as well as diurnal fluctuations (fig. 4B). The downward trends indicate compaction of the aquifer system, and the upward trends indicate vertical expansion of the aquifer system. Positive values indicate net compaction, and negative values indicate net expansion relative to the first measurement. Aquifersystem deformation occurs in response to short-term (daily) tidal cycles, which are superimposed on the seasonal responses to water-level changes in the Deep aquifer and reflected in water levels measured in EBAY3. Compaction is related to water-level drawdown in the Deep aquifer, and expansion is related to water-level recovery.

Other factors that potentially can affect the compaction of the aquifer system and compaction measurements include atmospheric loading caused by changes in barometric pressure at land surface, and diurnal fluctuations of shelter and equipment temperatures. The effects of atmospheric pressure variations on compaction measurements were observed to be fairly insignificant at other extensometer installations (Pavelko, 2000; Sneed and Galloway, 2000) and likely had little influence on compaction measurements at the bayside extensometers. The effects of temperature variations on compaction measurements were observed to be significant at an uninsulated extensometer shelter in Las Vegas, Nevada, but were insignificant at an insulated extensometer shelter in Antelope Valley, California (Pavelko, 2000; Sneed and Galloway, 2000). The extensometer shelter at Bayside is insulated, and diurnal temperature fluctuations were fairly small compared to the desert climates of Las Vegas and Antelope Valley, indicating temperature variations likely did not significantly influence compaction measurements.

At times, the deep extensometer data were degraded by downhole friction. The friction likely is caused by contact of the 2-in.-extensometer pipe with the 6-in.-casing. This contact could be a result of a non-plumb 2-in.-pipe, 6-in.-pipe, the borehole, some, or all of these things. When downhole friction occurred, the deep extensometer was adjusted until the friction was eliminated. The extensometer record indicated degradation by friction from July 30, 2008, to November 20, 2008. During this period, the deep extensometer record was truncated, indicating that the friction was great enough to restrict the extensometer pipe from moving through the full range. Another instance of downhole friction occurred between May 8, 2009, and June 23, 2009. During this period, the deep extensometer record was noisy, indicating that the friction restricted movement of the extensometer pipe for short periods before the stress threshold was reached, releasing the pipe and causing the large swing in values shown in the record (fig. 4B).

During periods when data from the deep extensometer were not degraded by downhole friction (for example, November 20, 2008-May 7, 2009), the data from the shallow and deep extensometers showed similar timing and magnitude of deformation. This similarity between data indicates that, for the range of stress occurring since the extensometers were instrumented, nearly all of the deformation at the Bayside site took place from 30 to $696 \mathrm{fbls}$, and that there was only a small amount of deformation from 696 to 1,040 fbls.

\section{Slug Tests}

Slug tests were performed to estimate hydraulic conductivity of the hydrogeologic units next to the screened zones. Water levels were measured in each piezometer before and after the slug tests. The number of tests analyzed, dampening coefficient (which accounts for the oscillation in the water level), estimated hydraulic conductivity, and the root-mean-square error, in addition to water levels for each piezometer, are presented in table 5. The hydraulic conductivity of the sediments surrounding piezometer EBAY3 within the Deep aquifer zone was estimated to be 32 feet per day (ft/d). Hydraulic conductivities of the sediments surrounding the remaining piezometers ranged from 0.34 to $120 \mathrm{ft} / \mathrm{d}$. The slug-test time-series data sets and the computations of estimated hydraulic conductivities are on file at the USGS California Water Science Center, Sacramento, California.

\section{Groundwater Quality}

Results from the analyses of groundwater samples collected from the four piezometer sites are presented by constituent group in tables 6 through 10. Groundwaterquality results from the EBAY piezometers, including some constituents not reported here, have previously been published by Ray and others (2009). Some of these results are presented again here for convenience and comparison to pore-water quality from the same location.

Field and laboratory measurements of water-quality indicators in groundwater, such as turbidity, dissolved oxygen, water temperature, $\mathrm{pH}$, specific conductance, and alkalinity, are presented in table 6. Turbidity is caused by suspended and dissolved matter, such as clay or silt, and can make water appear cloudy or muddy (Anderson, 2005). Natural turbidity concentrations in groundwater are typically less than 5 nephelometric turbidity ratio units (NTRU), although values 
Table 5. Results of slug tests from monitoring wells, Alameda County, California.

[Abbreviations: fbls, feet below land surface; ft, feet; ft/day, feet per day; mm/dd/yyyy, month/day/year; 1/sec, per second]

\begin{tabular}{|c|c|c|c|c|c|c|c|c|c|}
\hline $\begin{array}{c}\text { Well } \\
\text { identification } \\
\text { number }\end{array}$ & $\begin{array}{c}\text { Date } \\
\text { (mm/dd/yyyy) }\end{array}$ & $\begin{array}{l}\text { Depth to } \\
\text { water prior } \\
\text { to test } \\
\text { (fbls) }\end{array}$ & $\begin{array}{l}\text { Depth to } \\
\text { water } \\
\text { after test } \\
\text { (fbls) }\end{array}$ & $\begin{array}{l}\text { Number } \\
\text { of tests }\end{array}$ & $\begin{array}{c}\text { Dampening } \\
\text { coefficient } \\
(1 / \text { sec })\end{array}$ & $\begin{array}{l}\text { Hydraulic } \\
\text { conductivity } \\
\text { (ft/day) }\end{array}$ & $\begin{array}{l}\text { Squared } \\
\text { error } \\
\text { (ft) }\end{array}$ & $\begin{array}{c}\text { Top of } \\
\text { screen } \\
\text { (fbls) }\end{array}$ & $\begin{array}{c}\text { Bottom of } \\
\text { screen } \\
\text { (fbls) }\end{array}$ \\
\hline EBAY2 & $07 / 30 / 2007$ & 25.85 & 25.56 & 12 & 2.68 & 9.6 & 0.09 & 830 & 860 \\
\hline${ }^{1}$ EBAY3 & $07 / 30 / 2007$ & 14.56 & 14.97 & 9 & 4.14 & 32 & 0.18 & 530 & 550 \\
\hline${ }^{1} \mathrm{EBAY} 3$ & 07/30/2007 & 14.56 & 14.97 & 9 & 4.14 & 32 & 0.18 & 570 & 590 \\
\hline EBAY5 & $07 / 31 / 2007$ & 2.07 & 1.93 & 16 & 0.01 & 4.2 & 0.06 & 128 & 138 \\
\hline EBAY6 & $07 / 31 / 2007$ & 3.86 & 3.89 & 15 & 0.01 & 5.6 & 0.08 & 35 & 45 \\
\hline MW-FH & 08/03/2007 & 45.73 & 45.85 & 12 & 4.10 & 51 & 0.16 & 500 & 530 \\
\hline${ }^{1} \mathrm{MW}-1$ & 08/01/2007 & 17.53 & 17.40 & 14 & 4.07 & 31 & 0.20 & 520 & 550 \\
\hline${ }^{1} \mathrm{MW}-1$ & $08 / 01 / 2007$ & 17.53 & 17.40 & 14 & 4.07 & 31 & 0.20 & 570 & 590 \\
\hline${ }^{1} \mathrm{OW} 3$ & 08/01/2007 & 19.13 & 18.85 & 14 & 4.10 & 24 & 0.28 & 575 & 595 \\
\hline${ }^{1} \mathrm{OW} 3$ & 08/01/2007 & 19.13 & 18.85 & 14 & 4.10 & 24 & 0.28 & 625 & 655 \\
\hline MW-3 & $08 / 01 / 2007$ & 19.69 & 19.02 & 15 & 4.06 & 8.7 & 0.26 & 520 & 650 \\
\hline MW-4 & $08 / 01 / 2007$ & 17.21 & 17.70 & 13 & 4.02 & 14 & 0.21 & 520 & 650 \\
\hline MW-5D & $08 / 02 / 2007$ & 22.72 & 22.79 & 18 & 4.13 & 120 & 0.14 & 500 & 630 \\
\hline MW-6 & $08 / 02 / 2007$ & 18.44 & 18.50 & 18 & 3.84 & 27 & 0.09 & 480 & 650 \\
\hline MW-7 & 08/02/2007 & 15.45 & 15.33 & 18 & 3.64 & 19 & 0.09 & 510 & 630 \\
\hline
\end{tabular}

${ }^{1}$ Monitoring wells with multiple screened intervals.

of up to 19 NTRU have been reported in natural systems (Nightingale and Bianchi, 1977; Strausberg, 1983; Puls and Powell, 1992). At Bayside, turbidity ranged from 0.1 to 17 NTRU and had a mean and median of 4.5 and 0.25 NTRU, respectively. EBAY6, at 17 NTRU, had a markedly higher turbidity than the other EBAY piezometers. Turbidity results for EBKA1, EBKA2, and EBSP3 were high, at 206, 28, and 50 NTRU, respectively, and are not indicative of NTRU values representing environmental conditions. Turbidity results for all other piezometers were less than 5 NTRU (table 6).

Specific conductance and $\mathrm{pH}$ were measured in the field and in the laboratory for most groundwater samples. Laboratory values for $\mathrm{pH}$ and specific conductance can differ from field values because of exposure to the atmosphere. Field $\mathrm{pH}$ values were not collected from piezometers at the Stenzel Park site because of equipment failure. The $\mathrm{pH}$ values measured in the field at the other three locations ranged from 6.5 to $8.2 \mathrm{pH}$ units (table 6).

Dissolved oxygen and specific conductance are used as indicators of natural processes that control water chemistry. All piezometers had dissolved oxygen readings of less than 1 milligram per liter $(\mathrm{mg} / \mathrm{L})$, with the exception of the deep piezometer EBKA1, where it was $2.3 \mathrm{mg} / \mathrm{L}$. Dissolved oxygen was not detected in two piezometers at the Bayside site (EBAY2 and EBAY3). Specific conductance measured in the field ranged from 517 to 98,900 microsiemens per centimeter $(\mu \mathrm{S} / \mathrm{cm})$. Piezometers at the Bayside site had both the lowest (EBAY3) and the highest (EBAY6) values. Piezometer EBAY6, the shallowest of the pizeometers, had a specific conductance of $98,900 \mu \mathrm{S} / \mathrm{cm}$, which was much greater than any of the other piezometers at all of the sites (table 6 ) and is consistent with the conductance log shown in figure $2 \mathrm{~A}$.

Alkalinity, which measures the ability of a sample to neutralize strong acid, was measured in the field for the EBAY piezometers only, but samples from all piezometers were sent to the NWQL for alkalinity analysis. Field alkalinity, averaged from two replicate measurements, from the five EBAY piezometers ranged from 148 to $389 \mathrm{mg} / \mathrm{L}$. These results were consistently lower, yet comparable to lab results of alkalinity analysis from the same piezometers, which ranged from 156 to $402 \mathrm{mg} / \mathrm{L}$. The entire suite of results from lab analyses of alkalinity was within the previously reported range. The lowest observed alkalinity values were from EBAY3, and the highest were from EBAY6. Results from field and laboratory alkalinity analyses are presented in table 6 . 


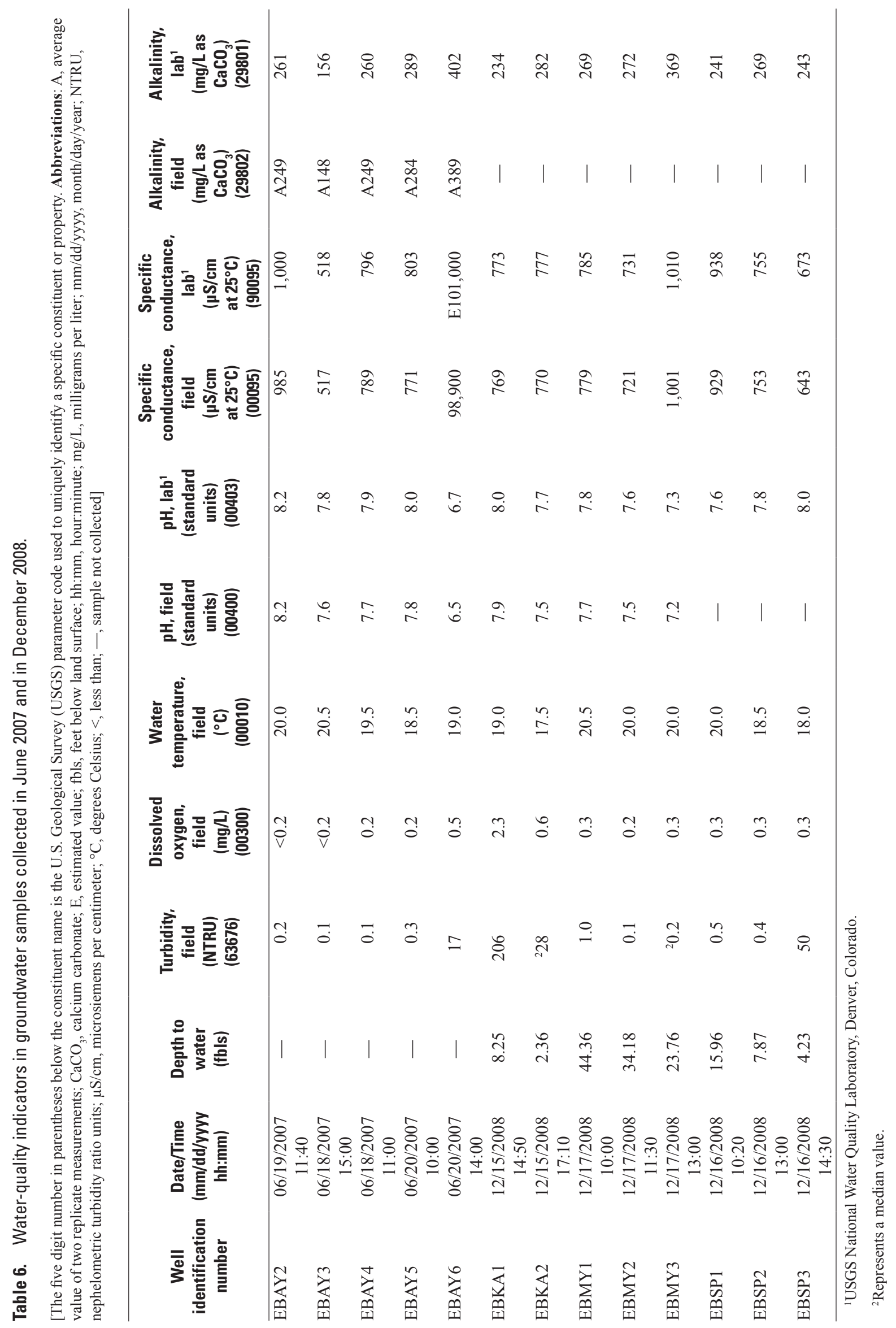


Nutrient samples were collected only from the EBAY piezometers 2-6. Results are presented in table 7 for reference and comparison to pore-water results later in the report. For a more detailed discussion of these results see Ray and others (2009). Ammonia (as nitrogen) was detected in four of the five groundwater samples-EBAY3 was the exception-and concentrations ranged from 0.167 to $2.46 \mathrm{mg} / \mathrm{L}$. Nitrate plus nitrite (as nitrogen) was detected only in piezometer EBAY3. Nitrite (as nitrogen) was not detected in the samples. Orthophospate (as phosphorus) was detected in all groundwater samples, with concentrations ranging from 0.146 to $1.27 \mathrm{mg} / \mathrm{L}$. Total nitrogen (nitrate, nitrite, ammonia, and organic nitrogen), as nitrogen, was detected in all piezometers, with concentrations ranging from 0.19 to $2.17 \mathrm{mg} / \mathrm{L}$. EBAY6 showed noticeably higher concentrations for detected constituents than any of the deeper piezometers (table 7).

Samples from 13 piezometers were analyzed for 10 different ions and total dissolved solids (TDS; table 8). Groundwater samples from EBAY6, the shallowest of the 14 piezometers, showed the highest concentrations of all of the ion constituents (table 8), except fluoride, iodide, and silica. Groundwater samples from EBAY3 exhibited the lowest concentrations of calcium, magnesium, potassium, bromide, chloride, sulfate, and total dissolved solids.

In samples collected from 13 piezometers, 24 trace elements were analyzed (table 9). Ten of the elements were detected in all piezometers: arsenic, barium, boron, lithium, manganese, molybdenum, nickel, strontium, uranium, and vanadium. Four of the elements - antimony, cadmium, cobalt and tungsten - had a detection frequency of 92 percent, whereas chromium and iron had slightly lower detection frequencies, at 85 and 69 percent, respectively. Aluminum, copper, selenium, and zinc had detection frequencies of less

Table 7. Nutrients in groundwater samples collected in June 2007 and analyzed by the U.S. Geological Survey (USGS) National Water Quality Laboratory, Denver, Colorado.

[The five digit number in parentheses below the constituent name is the USGS parameter code used to uniquely identify a specific constituent or property. Abbreviations: ID, identification; mg/L, milligrams per liter; <, less than]

\begin{tabular}{|c|c|c|c|c|c|}
\hline $\begin{array}{c}\text { Well } \\
\text { ID } \\
\text { number }\end{array}$ & $\begin{array}{c}\text { Ammonia, } \\
\text { as } \\
\text { nitrogen } \\
\text { (mg/L) } \\
(00608)\end{array}$ & $\begin{array}{l}\text { Nitrate } \\
\text { plus } \\
\text { nitrite, } \\
\text { as } \\
\text { nitrogen } \\
\text { (mg/L) } \\
\text { (00631) }\end{array}$ & $\begin{array}{c}\text { Nitrite, } \\
\text { as } \\
\text { nitrogen } \\
\text { (mg/L) } \\
\text { (00613) }\end{array}$ & $\begin{array}{l}\text { Orthophosphate, } \\
\text { as phosphorus } \\
\text { (mg/L) } \\
\text { (00671) }\end{array}$ & $\begin{array}{c}\text { Total nitrogen } \\
\text { (nitrate + } \\
\text { nitrite + } \\
\text { ammonia } \\
\text { + organic- } \\
\text { nitrogen), } \\
\text { as nitrogen } \\
\text { (mg/L) } \\
\text { (62854) }\end{array}$ \\
\hline EBAY2 & 0.167 & $<0.06$ & $<0.0$ & & 0 \\
\hline EBAY3 & $<0.020$ & 0.36 & $<0.002$ & 0.146 & 0.40 \\
\hline EBAY4 & 0.183 & $<0.06$ & $<0.002$ & 0.428 & 0.23 \\
\hline EBAY5 & 0.728 & $<0.06$ & $<0.002$ & 0.990 & 0.68 \\
\hline EBAY6 & 2.46 & $<0.06$ & $<0.002$ & 1.27 & 2.17 \\
\hline
\end{tabular}

than 50 percent, whereas beryllium, lead, silver, and thallium were not detected in any of the piezometer samples. Similar to results of constituent concentrations, samples from EBAY6 showed the highest concentrations for most of the elements. The samples from EBAY6 also had nine elements that were not detected at the standard limits, but detection limits were raised because of dilution of the sample for analysis (table 9). Groundwater samples from EBAY3 exhibited the lowest concentrations for aluminum, arsenic, barium, cadmium, copper, lithium, strontium, and uranium.

The isotopic ratios of oxygen and hydrogen in water, as well as tritium and carbon-14 activities, were determined for most piezometer samples (table 10). The isotopic ratios of oxygen and hydrogen in water help infer the source of the groundwater recharge. These stable-isotopic ratios fall along the global meteoric water line. Generally, the stable-isotopic analyses of groundwater and pore-water showed similar deuterium and oxygen-18 values at similar depths (fig. 5). The groundwater sample from EBAY3 (585 fbls) contained less deuterium and oxygen than the other samples, however, indicating a recharge source from a higher elevation or an inland location. Tritium is a naturally occurring radioisotope of hydrogen that decays to helium-3. As tritium decays, its detectable concentration decreases. In this way, tritium can be used to distinguish between groundwater that was recently recharged and older groundwater (Michel, 1989). Tritium concentrations in groundwater from piezometers sampled in this study ranged from undetectable to 10.6 picocuries per liter ( $\mathrm{pCi} / \mathrm{L}$; table 10), with the highest concentration found at EBMY3. Tritium concentrations from samples collected at EBAY3 were among the upper range measured in this study $(4.2 \mathrm{pCi} / \mathrm{L})$, indicating more recent recharge. Carbon-14 is a naturally occurring, unstable isotope of carbon that can be used to estimate groundwater age from the time of recharge. Carbon-14 data are reported as percent modern carbon (table 10). Results for carbon-14 from these piezometers ranged from 2.24 to 93.49 percent modern carbon. 


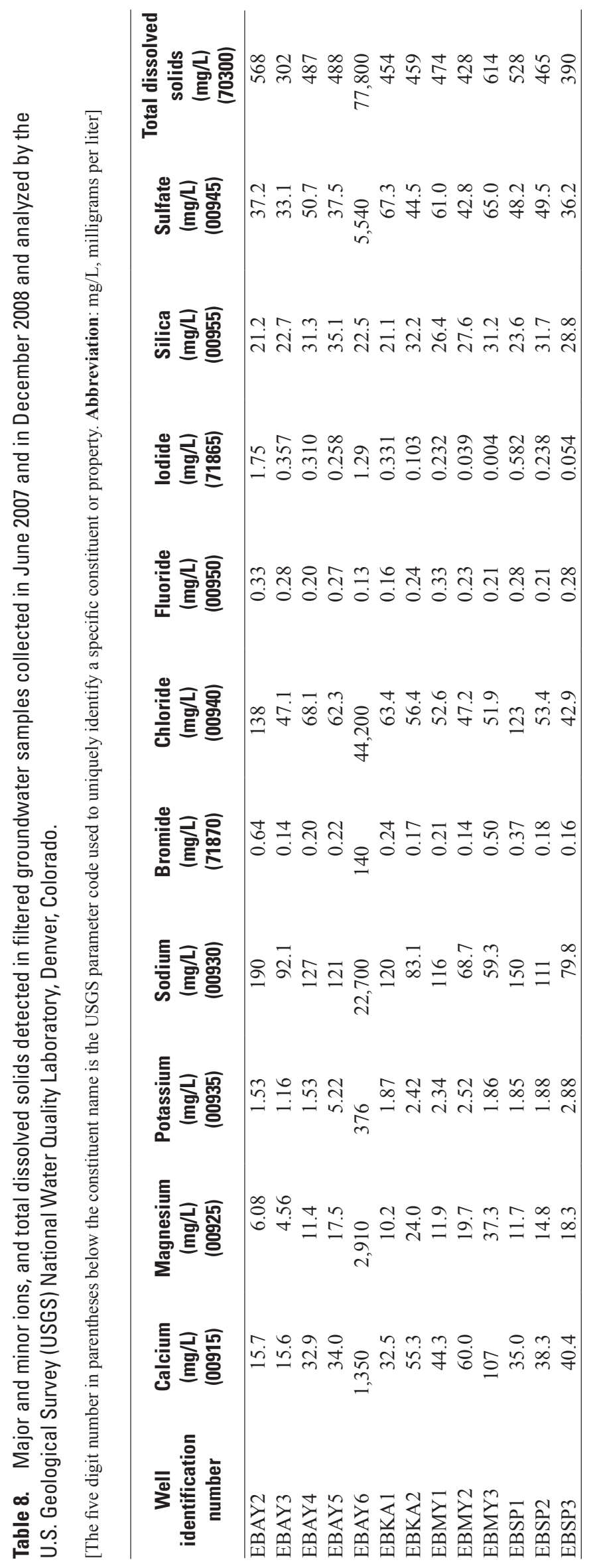




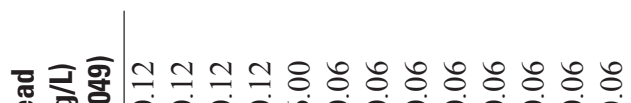

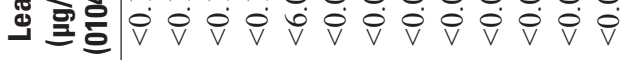

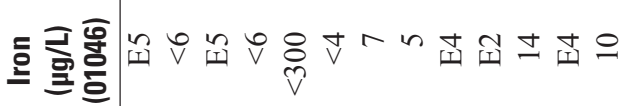

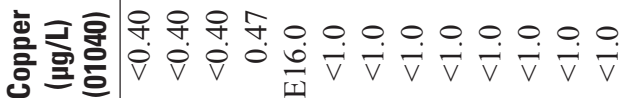

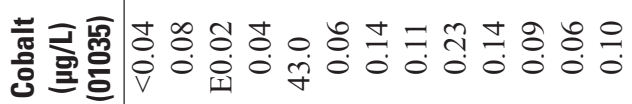

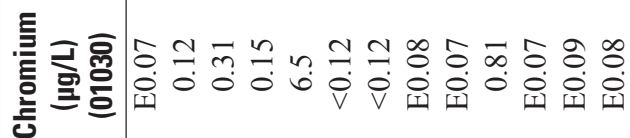

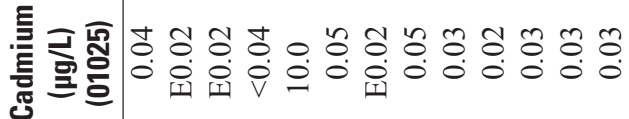

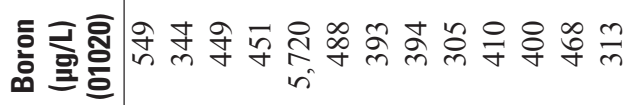

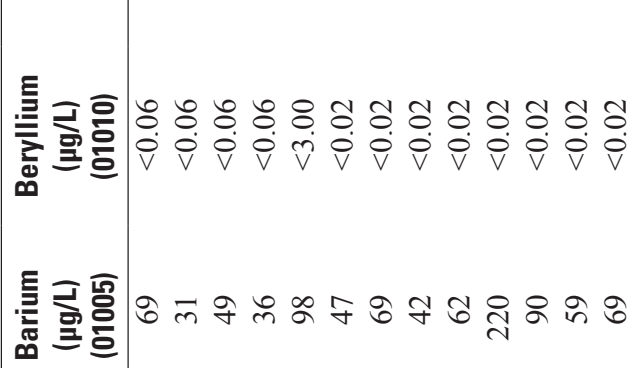

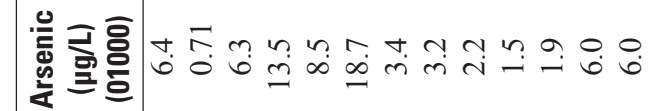

品

崽

它

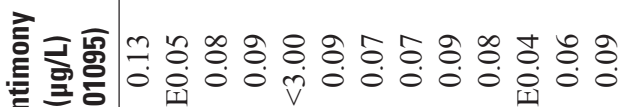
루ㄴㅡㅡ

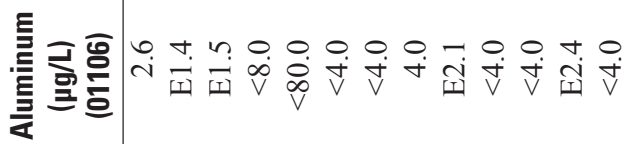

ष

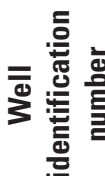

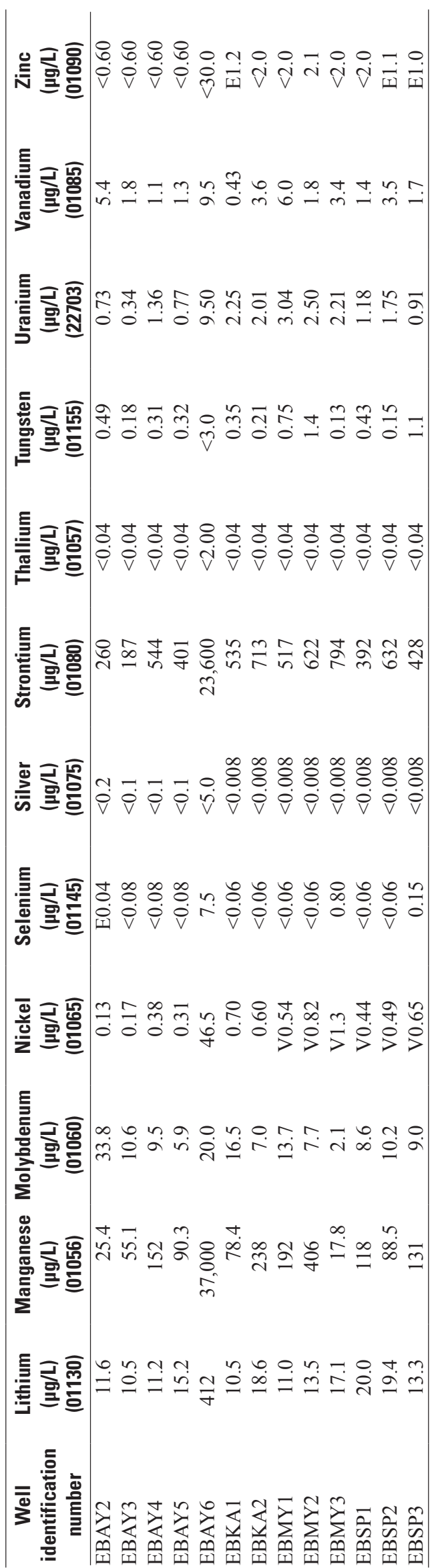


Table 10. Stable isotope ratios, tritium, and carbon-14 activities in groundwater.

[The five digit number in parentheses below the constituent name is the U.S. Geological Survey (USGS) parameter code used to uniquely identify a specific constituent or property. Stable isotope ratios are reported in the standard delta notation $(\delta)$, the ratio of a heavier isotope to the more common lighter isotope of that element, relative to a standard reference material. Abbreviations: C, carbon; H, hydrogen; nc, sample not collected; O, oxygen; $\mathrm{pCi} / \mathrm{L}$, picocuries per liter; - not detected]

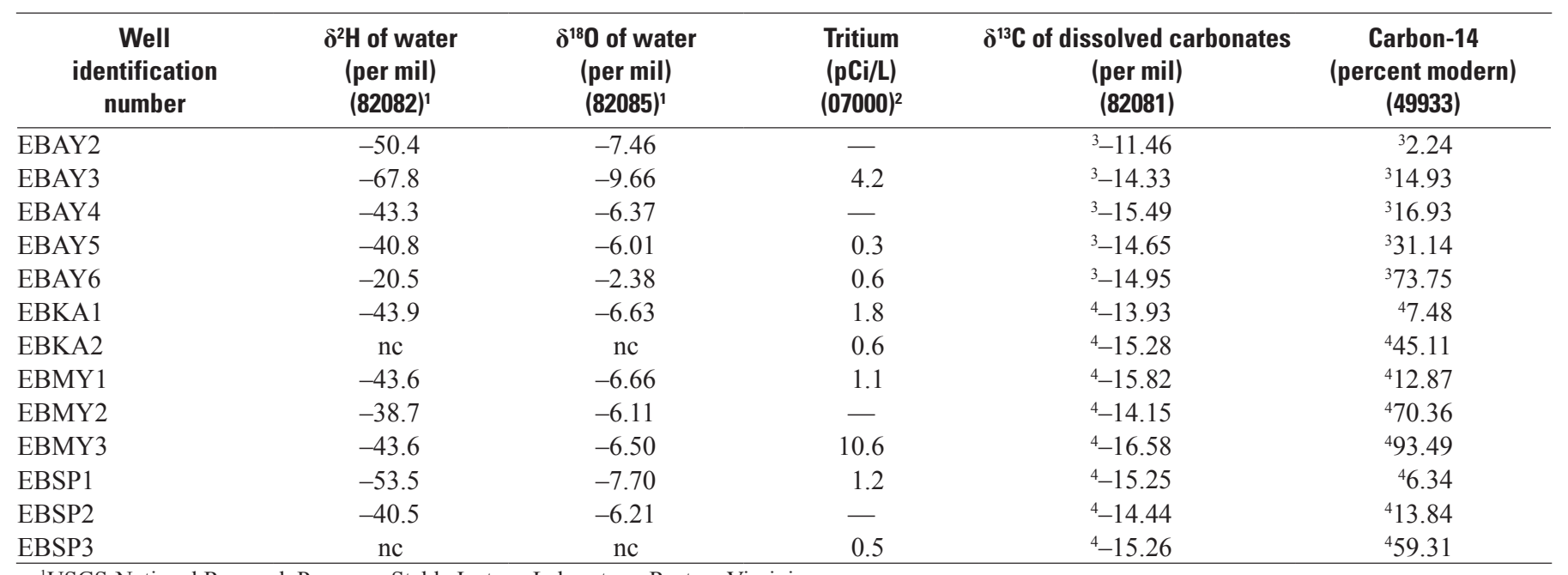

${ }^{1}$ USGS-National Research Program, Stable Isotope Laboratory, Reston, Virginia.

${ }^{2}$ USGS Tritium Laboratory, Menlo Park, California.

${ }^{3}$ University of Waterloo, Environmental Isotope Lab (CAN-UWIL); University of Arizona Accelerator Mass Spectrometry Lab (AZ-UAMSL).

${ }^{4}$ National Ocean Sciences Accelerator Mass Spectrometry Facility (NOSAMS).

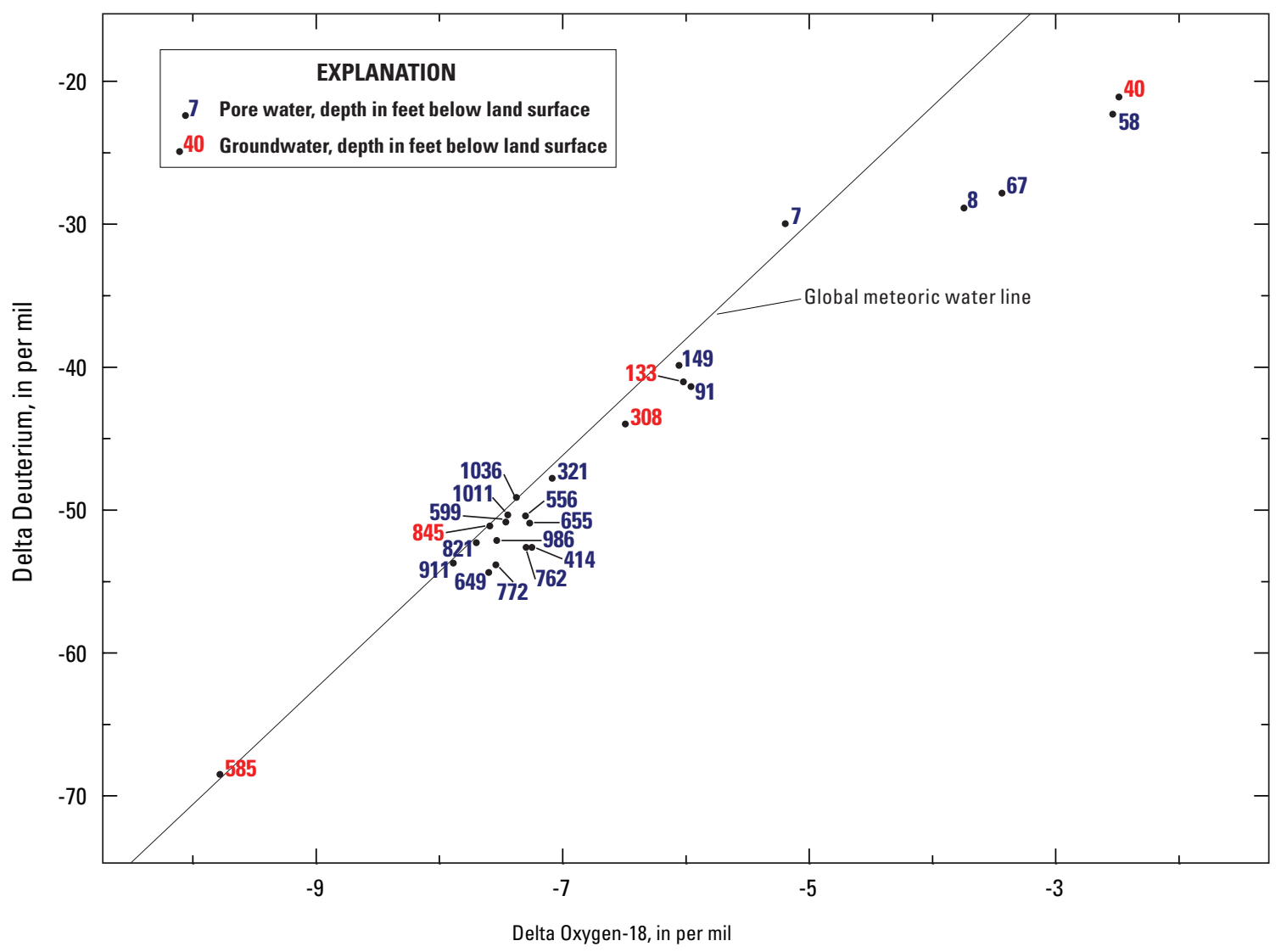

Figure 5. Graph showing cComparison of isotopic ratios of hydrogen and oxygen between pore-water and groundwater at similar depths from the East Bay Bayside Monitoring Site (EBAY) core and EBAY piezometers, respectively. 
Quality-Control Sample Results

Quality-control samples collected by the GAMA program for the June 2007 sampling event at Bayside were explained in detail by Ray and others (2009). Assessment of an additional field blank that was collected by the NAWQA program during the December 2008 sampling event at Kipp Academy, East Bay Mud Yard, and Stenzel Park revealed no detections in the blank sample, with the exception of nickel. We infer that the same process that caused the detection of nickel in the field blank $(0.34 \mu \mathrm{g} / \mathrm{L})$ could have contributed to the corresponding environmental samples. Because of this, a "V" code was applied to the trace nickel data from the December 2008 sampling event, indicating that the results could have been affected by contamination (table 9).

\section{Core Analyses}

\section{Physical and Mechanical Determinations}

Moisture content of the EBAY core is summarized in table 11. Moisture content is expressed both as water mass in cubic centimeters and as a percentage of weight in grams.

Saturated vertical hydraulic-conductivity tests for 20 samples ranged from 0.0004 to 23.7 centimeters per day $(\mathrm{cm} / \mathrm{d})$, with a geometric mean of $0.04 \mathrm{~cm} / \mathrm{d}$ (table 12). The test gradient varied according to sample material and ranged from 21 to $400 \mathrm{kPa}$.

Table 11. Moisture content by mass and percent for core samples from the East Bay Bayside Monitoring Site (EBAY) borehole.

[Abbreviations: cc, cubic centimeters; ft, feet; g, grams; hr, hours; LSD, land surface datum]

\begin{tabular}{|c|c|c|c|c|c|c|c|c|c|c|c|c|c|}
\hline $\begin{array}{c}\text { Core } \\
\text { number }\end{array}$ & $\begin{array}{c}\text { Sample } \\
\text { depth } \\
\text { (ft below } \\
\text { LSD) }\end{array}$ & $\begin{array}{c}\text { Wet } \\
\text { weight } \\
\text { (g) }\end{array}$ & $\begin{array}{c}\text { Dry } \\
\text { weight } \\
\text { (g) }\end{array}$ & $\begin{array}{c}\text { Drying } \\
\text { time } \\
\text { (hr) }\end{array}$ & $\begin{array}{c}\text { Moisture } \\
\text { content } \\
\text { by mass } \\
\text { (cc) }\end{array}$ & $\begin{array}{c}\text { Moisture } \\
\text { content } \\
\text { (percent) }\end{array}$ & $\begin{array}{c}\text { Core } \\
\text { number }\end{array}$ & $\begin{array}{c}\text { Sample } \\
\text { depth } \\
\text { (ft below } \\
\text { LSD) }\end{array}$ & $\begin{array}{c}\text { Wet } \\
\text { weight } \\
\text { (g) }\end{array}$ & $\begin{array}{c}\text { Dry } \\
\text { weight } \\
\text { (g) }\end{array}$ & $\begin{array}{c}\text { Drying } \\
\text { time } \\
\text { (hr) }\end{array}$ & $\begin{array}{c}\text { Moisture } \\
\text { content } \\
\text { by mass } \\
\text { (cc) }\end{array}$ & $\begin{array}{r}\text { Moisture } \\
\text { content } \\
\text { (percent) }\end{array}$ \\
\hline$\overline{\text { EBAY_1 }}$ & 3.0 & 34.93 & 26.19 & 49 & 8.74 & 25.0 & EBAY_34 & 168.4 & 37.49 & 30.64 & 77 & 6.85 & 18.3 \\
\hline EBAY_2 & 6.3 & 25.02 & 15.1 & 42 & 9.92 & 39.6 & EBAY_35 & 172.1 & 38.02 & 30.86 & 75 & 7.16 & 18.8 \\
\hline EBAY_3 & 10.7 & 37.23 & 27.06 & 40 & 10.17 & 27.3 & EBAY_36 & 178.4 & 35.25 & 28.61 & 74 & 6.64 & 18.8 \\
\hline EBAY_6 & 26.2 & 38.52 & 32.6 & 49 & 5.92 & 15.4 & EBAY_40 & 325.9 & 42.60 & 34.38 & 55 & 8.22 & 19.3 \\
\hline EBAY_11 & 51.1 & 28.66 & 22.86 & 40 & 5.80 & 20.2 & EBAY_41 & 414.0 & 44.52 & 36.2 & 54 & 8.32 & 18.7 \\
\hline EBAY_12 & 58.0 & 30.43 & 25.27 & 47 & 5.16 & 17.0 & EBAY_44 & 498.0 & 35.18 & 29.6 & 51 & 5.58 & 15.9 \\
\hline EBAY_13 & 62.4 & 30.90 & 25.49 & 44 & 5.41 & 17.5 & EBAY 48 & 556.0 & 39.03 & 31.82 & 122 & 7.21 & 18.5 \\
\hline EBAY_14 & 67.2 & 30.77 & 26.49 & 44 & 4.28 & 13.9 & EBAY_50 & 594.2 & 69.55 & 60.35 & 118 & 9.20 & 13.2 \\
\hline EBAY_19 & 94.1 & 32.50 & 26.54 & 49 & 5.96 & 18.3 & EBAY_58 & 762.0 & 38.62 & 30.13 & 97 & 8.49 & 22.0 \\
\hline EBAY_19 & 90.8 & 42.34 & 34.69 & 48 & 7.65 & 18.1 & EBAY_59 & 765.3 & 38.08 & 29.61 & 95 & 8.47 & 22.2 \\
\hline EBAY_20 & 95.5 & 37.99 & 28.44 & 48 & 9.55 & 25.1 & EBAY_60 & 771.0 & 33.97 & 27.49 & 95 & 6.48 & 19.1 \\
\hline EBAY_21 & 102.1 & 33.30 & 27.19 & 45 & 6.11 & 18.3 & EBAY_60 & 773.9 & 25.20 & 20.53 & 107 & 4.67 & 18.5 \\
\hline EBAY_22 & 109.6 & 39.04 & 30.37 & 44 & 8.67 & 22.2 & EBAY_61 & 778.4 & 34.35 & 28.9 & 92 & 5.45 & 15.9 \\
\hline EBAY_23 & 112.1 & 41.75 & 34.29 & 43 & 7.46 & 17.9 & EBAY_63 & 826.8 & 35.62 & 29.5 & 90 & 6.12 & 17.2 \\
\hline EBAY_24 & 116.5 & 36.24 & 28.79 & 42 & 7.45 & 20.6 & EBAY_64 & 831.5 & 41.48 & 34.36 & 91 & 7.12 & 17.2 \\
\hline EBAY_25 & 122.3 & 32.83 & 28.86 & 41 & 3.97 & 12.1 & EBAY_66 & 910.4 & 31.67 & 26.02 & 25 & 5.65 & 17.8 \\
\hline EBAY_26 & 128.2 & 28.13 & 22.43 & 105 & 5.70 & 20.3 & EBAY_67 & 915.7 & 36.68 & 30.93 & 23 & 5.75 & 15.7 \\
\hline EBAY_28 & 136.7 & 32.94 & 22.52 & 101 & 10.42 & 31.6 & EBAY_68 & 987.6 & 32.37 & 27.99 & 20 & 4.38 & 13.5 \\
\hline
\end{tabular}


Table 12. Vertical hydraulic conductivity of selected cores from the East Bay Bayside Monitoring Site (EBAY) and East Bay Extensometer-2 Monitoring Site (EXT2) boreholes.

[Abbreviations: ft, feet; LSD, land surface datum; cm/d, centimeters per day; kPa, kilopascals]

\begin{tabular}{|c|c|c|c|}
\hline $\begin{array}{c}\text { Core } \\
\text { number }\end{array}$ & $\begin{array}{c}\text { Sample } \\
\text { depth } \\
\text { (ft below } \\
\text { LSD) }\end{array}$ & $\begin{array}{c}\text { Saturated } \\
\text { hydraulic } \\
\text { conductivity } \\
(\mathrm{cm} / \mathrm{d})\end{array}$ & $\begin{array}{c}\text { Test } \\
\text { gradient } \\
(\mathrm{kPa})\end{array}$ \\
\hline EBAY_2 & 8.8 & 0.3062 & 200 \\
\hline EBAY_2 & 8.8 & 0.2223 & 200 \\
\hline EXT2_2 & 42.5 & 0.0448 & 200 \\
\hline EXT2_2 & 42.5 & 0.0655 & 200 \\
\hline EBAY_12 & 58.3 & 1.5065 & 119 \\
\hline EBAY_12 & 58.3 & 2.3704 & 200 \\
\hline EBAY_15 & 73.4 & 0.4801 & 200 \\
\hline EBAY_15 & 73.4 & 0.4287 & 300 \\
\hline EBAY_18 & 88.2 & 0.0016 & 282 \\
\hline EBAY_20 & 99.1 & 21.2827 & 21 \\
\hline EBAY_20 & 99.1 & 23.7224 & 28 \\
\hline EBAY_22 & 108.3 & 0.0554 & 84 \\
\hline EBAY_28 & 135.8 & 0.0098 & 42 \\
\hline EBAY_28 & 135.8 & 0.0099 & 210 \\
\hline EBAY 29 & 142.5 & 0.0035 & 42 \\
\hline EBAY_29 & 142.5 & 0.0031 & 210 \\
\hline EBAY 36 & 179.0 & 0.0006 & 210 \\
\hline EBAY_39 & 321.6 & 0.0230 & 182 \\
\hline
\end{tabular}

\begin{tabular}{lccc}
\hline $\begin{array}{c}\text { Core } \\
\text { number }\end{array}$ & $\begin{array}{c}\text { Sample } \\
\text { depth } \\
\text { (ft below } \\
\text { LSD) }\end{array}$ & $\begin{array}{c}\text { Saturated } \\
\text { hydraulic } \\
\text { conductivity } \\
\text { (cm/d) }\end{array}$ & $\begin{array}{c}\text { Test } \\
\text { gradient } \\
\text { (kPa) }\end{array}$ \\
\hline EBAY_39 & 321.6 & 0.0151 & 100 \\
EBAY_41 & 412.9 & 0.0088 & 182 \\
EBAY_41 & 412.9 & 0.0077 & 250 \\
EBAY_44 & 499.1 & 0.0017 & 182 \\
EBAY_44 & 499.1 & 0.0006 & 300 \\
EBAY_48 & 557.1 & 0.0013 & 305 \\
EBAY_50 & 591.1 & 0.0004 & 200 \\
EBAY_50 & 591.1 & 0.0009 & 400 \\
EBAY_60 & 772.6 & 0.0100 & 300 \\
EBAY_60 & 772.6 & 0.0063 & 300 \\
EBAY_63 & 827.6 & 0.4219 & 126 \\
EBAY_63 & 827.6 & 0.3740 & 35 \\
EBAY_67 & 916.8 & 5.4168 & 35 \\
EBAY_67 & 916.8 & 5.0799 & 49 \\
EBAY_72 & $1,017.9$ & 0.0125 & 210 \\
EBAY_72 & $1,017.9$ & 0.0066 & 300 \\
EBAY_73 & $1,034.4$ & 0.0273 & 300 \\
EBAY_73 & $1,034.4$ & 0.0231 & 318 \\
\hline
\end{tabular}

For the 20 samples for which vertical hydraulic conductivity was measured, bulk density ranged from 0.76 to 1.79 grams per cubic centimeter $\left(\mathrm{g} / \mathrm{cm}^{3}\right)$ and had a geometric mean of $1.50 \mathrm{~g} / \mathrm{cm}^{3}$ (table 13 ). Porosity and volumetric water content ranged from 34.6 to 70.6 percent and had geometric means of 44 and 43 percent, respectively. Effective porosity ranged from 28.2 to 62.1 percent and had a geometric mean of 36 percent; saturation and effective saturation ranged from about 89 to 100 percent and had geometric means of 97 and 96 percent, respectively (table 13). Grain size, strength, density, and results of Atterberg tests performed on selected cores are described in detail in Bennett and others (2009).

The results of the consolidation tests on 17 samples are shown in table 14. Analysis of 1 of the 17 samples was aborted prior to completion; therefore, no coefficient of elastic consolidation $\left(\mathrm{C}_{\mathrm{r}}\right)$ was determined for that sample (EBAY_22). The fairly small ratios of past maximum stress to calculated effective stress indicated that, normally, the sediments are consolidated below about $135 \mathrm{ft}$. Shallow depths showed evidence of bioturbation and subaerial exposure (Robert Kayen, USGS, written commun., 2007). The sample EBAY_2 was determined to be disturbed because of its shallow depth and, therefore, was excluded from the calculations of minimums, maximums, and geometric means of the samples shown in table 14 and discussed here.
Elastic and inelastic specific-storage values, calculated from consolidation test results, generally decreased with depth. Elastic specific storage values ranged from $5.5 \times 10^{-6}$ to $5.8 \times 10^{-5}$ per foot $\left(\mathrm{ft}^{-1}\right)$, and inelastic specific storage values ranged from $7.7 \times 10^{-5}$ to $8.6 \times 10^{-4} \mathrm{ft}^{-1}$. The geometric mean of elastic specific storage for the clay samples was $1.6 \times 10^{-5}$ $\mathrm{ft}^{-1}$, which is greater than values reported by Sneed (2001) for samples collected from the San Joaquin Valley. Conversely, the geometric mean of inelastic specific-storage values for the clay samples was $1.9 \times 10^{-4} \mathrm{ft}^{-1}$, which is less than values reported by Sneed (2001).

\section{Age Dating}

Luminescence geochronology results for nine samples, ranging in depth from about 39 to $312 \mathrm{fbls}$, are shown in table 15. Quartz blue-light OSL methods applied to seven of the samples indicated that ages ranged from about 27,800 $( \pm 2,260)$ to $169,000( \pm 36,100)$ years old. The two deepest samples (173 and $312 \mathrm{fbls}$ ) were tested by using only feldspar infrared stimulated luminescence and yielded only minimum ages, which ranged from greater than 86,600 to greater than 119,000 years old, because the advanced age of these samples was beyond the capability of the Quartz blue-light OSL method (table 15). 
Table 13. Physical properties of selected cores from the East Bay Bayside Monitoring Site (EBAY) and East Bay Extensometer-2 Monitoring Site (EXT2) boreholes.

[Abbreviations: ft, feet; LSD, land surface datum; $\mathrm{g} / \mathrm{cm}^{3}$, grams per cubic centimeter; ${ }^{\circ} \mathrm{C}$, degrees Celsius]

\begin{tabular}{|c|c|c|c|c|c|c|c|c|}
\hline $\begin{array}{c}\text { Core } \\
\text { number }\end{array}$ & $\begin{array}{c}\text { Sample } \\
\text { depth } \\
\text { (ft below } \\
\text { LSD) }\end{array}$ & \multicolumn{4}{|c|}{$105^{\circ} \mathrm{C}$ oven calculations } & \multicolumn{3}{|c|}{ Relative humidity oven calculations } \\
\hline EBAY_2 & 8.8 & 0.76 & 70.6 & 70.6 & 100.0 & 8.5 & 62.1 & 100.0 \\
\hline EXT2_2 & 42.5 & 1.43 & 47.8 & 47.8 & 100.0 & 11.8 & 36.0 & 100.0 \\
\hline EBAY_12 & 58.3 & 1.63 & 40.3 & 39.0 & 96.7 & 7.8 & 32.5 & 96.0 \\
\hline EBAY_18 & 88.2 & 1.48 & 45.5 & 45.2 & 99.4 & 10.1 & 35.4 & 99.2 \\
\hline EBAY_20 & 99.1 & 1.74 & 35.9 & 35.0 & 97.4 & 7.0 & 28.9 & 96.7 \\
\hline EBAY_22 & 108.3 & 1.43 & 49.2 & 46.7 & 94.9 & 7.6 & 41.7 & 94.0 \\
\hline EBAY_28 & 135.8 & 1.19 & 60.2 & 54.4 & 90.3 & 6.1 & 54.1 & 89.2 \\
\hline EBAY_29 & 142.5 & 1.19 & 56.4 & 55.6 & 98.5 & 6.2 & 50.3 & 98.3 \\
\hline EBAY_36 & 179.0 & 1.70 & 40.0 & 39.1 & 97.6 & 5.5 & 34.5 & 97.2 \\
\hline EBAY_50 & 591.1 & 1.64 & 40.6 & 39.6 & 97.6 & 7.5 & 33.1 & 97.1 \\
\hline EBAY_60 & 772.6 & 1.50 & 46.0 & 44.5 & 96.8 & 13.3 & 32.7 & 95.6 \\
\hline EBAY_63 & 827.6 & 1.62 & 41.3 & 39.4 & 95.5 & 8.6 & 32.7 & 94.3 \\
\hline EBAY_67 & 916.8 & 1.61 & 41.3 & 39.1 & 94.6 & 9.3 & 32.1 & 93.1 \\
\hline EBAY_72 & $1,017.9$ & 1.61 & 44.5 & 41.2 & 92.5 & 10.9 & 33.7 & 90.1 \\
\hline EBAY 73 & $1,034.4$ & 1.79 & 37.1 & 34.6 & 93.3 & 8.9 & 28.2 & 91.3 \\
\hline
\end{tabular}

Table 14. Consolidation test results of selected cores from the East Bay Bayside Monitoring Site (EBAY) borehole.

[Abbreviations: $\mathrm{ft}$, feet; $\mathrm{ft}^{-1}$, per foot; $\mathrm{kPa}$, kilopascals; LSD, land surface datum; — , no data]

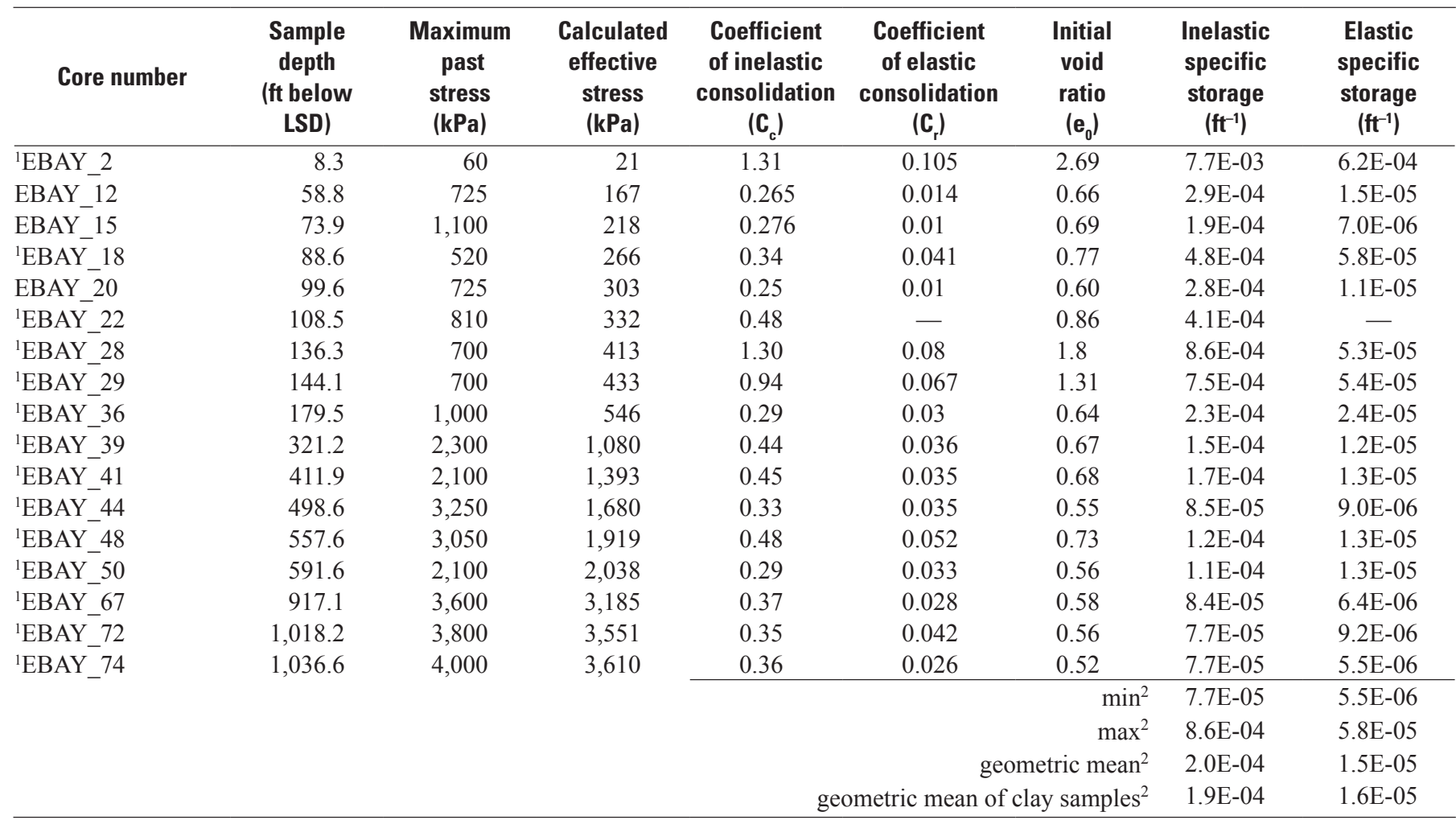

${ }^{1}$ Clay sample.

${ }^{2}$ Calculation excludes EBAY_2. 


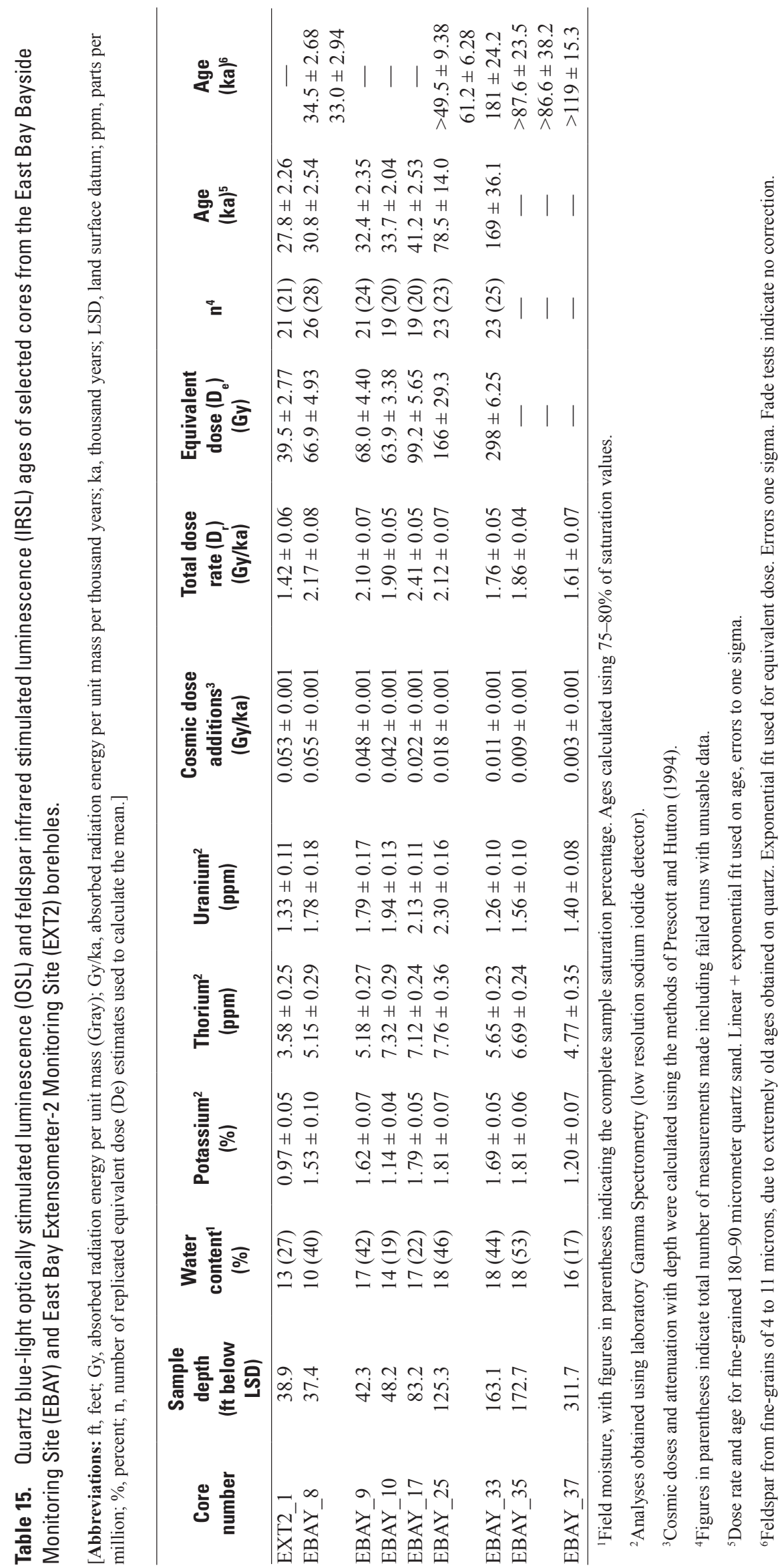




\section{Depositional Environment}

Core samples were inspected for foraminifera, which were quantified and identified, whereas ostracods, diatoms, and shell fragments were noted for presence only. Foraminifera specimens were found in EBAY_2, EBAY_28, and EBAY_29 and enumerated in only EBAY_28 and EBAY_29. A combination of diatoms, ostracods, and shell fragments was observed in EBAY_2, EBAY_22, EBAY_28, EBAY_29, and EBAY_36. The abundance of foraminifera in two core samples and the presence of foraminifera, diatoms, ostracods, and shell fragments in these five core samples are presented in table 16.

Eight species of benthic foraminifera, including two varieties of Elphidium excavatum, were identified in the EBAY core samples. Of these species, only two were abundant specimens (greater than 16 percent; table 16): Elphidiella hannai and Elphidium excavatum var. selseyensis. Common species (greater than 5 percent) included Ammonia beccarii, Buccella frigida, and Elphidium excavatum var. clavatum. Only rare specimens (less than 3 percent) of the other four species were encountered: Bolivina vaughani, Elphidium gunteri, Trochammina inflata, and Trochammina macrescens. Other biologic constituents recovered during the foraminifera analysis included diatoms, ostracods, and shell fragments.

Both arenaceous and calcareous foraminiferal species were represented in the EBAY core. All of these species are common today in shallow embayments and estuaries along the Pacific Coast of North America (Phleger, 1967; Scott and others, 1976; Jennings and Nelson, 1992; McCormick and others, 1994; McGann, 2007).
The two deepest samples containing foraminifera in the EBAY core were between 145 and 135 fbls. Sample EBAY_29 (tables 3 and 16) was characterized by dominant Elphidiella hannai (56 percent) and abundant Elphidium excavatum var. selseyensis (31 percent), as well as common Ammonia beccarii (6 percent). Species dominance was reversed in Sample EBAY_28, with higher percentages of Elphidium excavatum var. selseyensis (64 percent), abundant Elphidiella hannai (17 percent), and common Buccella frigida (7 percent), Elphidium excavatum var. clavatum (6 percent), and Ammonia beccarii (5 percent). These are typical modern deep to shallow subtidal estuarine foraminiferal assemblages found in areas of the San Francisco Bay estuary, such as San Pablo, Richardson, Central, and South bays (Means, 1965; Slater, 1965; Quinterno, 1968; Locke, 1971; Arnal and others, 1980). Similar assemblages also have been reported in late Pleistocene and Holocene estuarine deposits in San Francisco Bay along the San Francisco-Oakland Bay Bridge transect (McGann and others, 2002) and about $3.7 \mathrm{mi}$ south of the bridge along the proposed, but never built, Southern Crossing transect (Sloan, 1992). Of the three biofacies identified in these older sediments, an assemblage dominated by Elphidiella hannai (Sample EBAY_29) would be assigned to Biofacies $\mathrm{C}$, representing deep subtidal regions of about 39 to $72 \mathrm{ft}$ water depth and salinity of about 15 to 32 practical salinity units (psu). Sample EBAY_28, dominated by Elphidium excavatum (inclusive of both varieties, Elphidium excavatum var. selseyensis and Elphidium excavatum var. clavatum), would be referable to Biofacies B, indicative of shallow subtidal environments of water depths from about 7 to $49 \mathrm{ft}$ and salinity of about 10 to $30 \mathrm{psu}$ (Sloan, 1992; McGann and others, 2002).

Table 16. Percentage abundance of the benthic foraminifera in core from the East Bay Bayside Monitoring Site (EBAY) borehole.

[Abbreviations: ft, feet; LSD, land surface datum; X, presence of benthic foraminifera and other biological constituents in a non-statistical count; -, nondetect]

\begin{tabular}{|c|c|c|c|c|c|}
\hline \multirow{4}{*}{$\begin{array}{l}\text { Species/ } \\
\text { samples }\end{array}$} & \multicolumn{5}{|c|}{ Sample depth (ft below LSD) } \\
\hline & 7.00 & 109 & 137 & 141 & 179 \\
\hline & \multicolumn{5}{|c|}{ Core number } \\
\hline & EBAY_2 & EBAY_22 & EBAY_28 & EBAY_29 & EBAY_36 \\
\hline Ammonia beccarii & - & - & 5.2 & 6.4 & - \\
\hline Bolivina vaughani & - & - & - & 0.5 & - \\
\hline Buccella frigida & - & - & 6.9 & 3.4 & - \\
\hline Elphidiella hannai & - & - & 16.7 & 55.6 & - \\
\hline Elphidium excavatum clavatum & - & - & 5.9 & 1.1 & - \\
\hline Elphidium excavatum selseyensis & - & - & 64.1 & 30.6 & - \\
\hline Elphidium gunteri & - & - & 1.3 & 2.3 & - \\
\hline Trochammina inflata & $\mathrm{X}$ & - & - & - & - \\
\hline Trochammina macrescens & $\mathrm{X}$ & - & - & - & - \\
\hline Total count & - & - & 306 & 435 & - \\
\hline \multicolumn{6}{|c|}{ Other constituents } \\
\hline Diatoms & $\mathrm{X}$ & - & - & $\mathrm{X}$ & - \\
\hline Ostracods & - & $\mathrm{X}$ & - & $\mathrm{X}$ & $\mathrm{X}$ \\
\hline Shell fragments & - & - & $\mathrm{X}$ & - & $\mathrm{X}$ \\
\hline
\end{tabular}


The shallowest sediment-core sample containing foraminifera was EBAY_2 (tables 3 and 16). Two arenaceous species, Trochammina inflata and Trochammina macrescens, were present, and they were not observed elsewhere in the core. Recent assemblages with these two species have been reported from the mudflat, marsh, and brackish waters regions in Suisun, Richardson, and San Pablo bays in the San Francisco Bay estuary (Means, 1965; Slater, 1965; Locke, 1971; Connor, 1975). In the late Pleistocene and Holocene deposits under the bay, an assemblage dominated by Trochammina inflata would be assigned to Biofaces $\mathrm{A}$, indicative of intertidal mudflat and marsh conditions, water depths from about 0 to $7 \mathrm{ft}$, and a maximum salinity of about $10 \mathrm{psu}$. These relatively wide ranges in water temperature and salinity, in addition to a high organic input, contribute to making the mudflats, marshes, and brackish regions stressful environments, and foraminiferal faunas are typically characterized by low faunal diversity (Phleger, 1970; Murray, 1973). Commonly, calcareous taxa are absent in these marginal environments because they dissolve in the unfavorable physical and chemical conditions (e.g., low pH) within the sediments (Parker and Athern, 1959; Phleger, 1967; Scott and Medioli, 1980; Scott and Leckie, 1990; Jennings and Nelson, 1992).

Selection of samples for diatom analysis was guided by the results of the foraminifera analysis. Nearly all of the 31 core samples analyzed for foraminifera were taken from similar locations in the core that were selected for diatom analysis and were found barren of microfossils. Of the two samples where diatoms were observed, only one sample (EBAY_29) had diatoms in any abundance, and all were fragmented. The assemblage indicated marine to brackish conditions (Scott Starratt, U.S. Geological Survey, written commun., 2007).

\section{Mineralogy}

$\mathrm{X}$-ray diffraction results for 16 samples revealed clay and non-clay minerals composed an average of 40.8 and 59.2 percent of the core-sample mineralogy, respectively (table 17). Of the seven clay minerals identified by XRD, illite and smectite occur most frequently, at an average of 13 percent each, followed by chlorite, muscovite, biotite, kaolanite, and gibbsite (table 17). The relative abundances of clay minerals are greatest (greater than 50 percent) at depths of $142,499,547,557$, and $772 \mathrm{fbls}$, and are least at a depth of $767 \mathrm{fbls}$ ( fig. 6). Two of the segments, at depths of 547 and $557 \mathrm{fbls}$, that contained a relatively high abundance of clay lie within the Deep aquifer zone consisting of three coarse-sand and gravel beds. This is consistent with the resistivity logs from figure $2 A$ showing decreased resistivity at these depths, where clay is present, and increased resistivity at depths where sand and gravel are present.

Table 17. Relative abundance of minerals determined from $x$-ray defraction analyses of core samples collected from the EBAY borehole, San Lorenzo, California.

[Abbreviations: LSD, land surface datum]

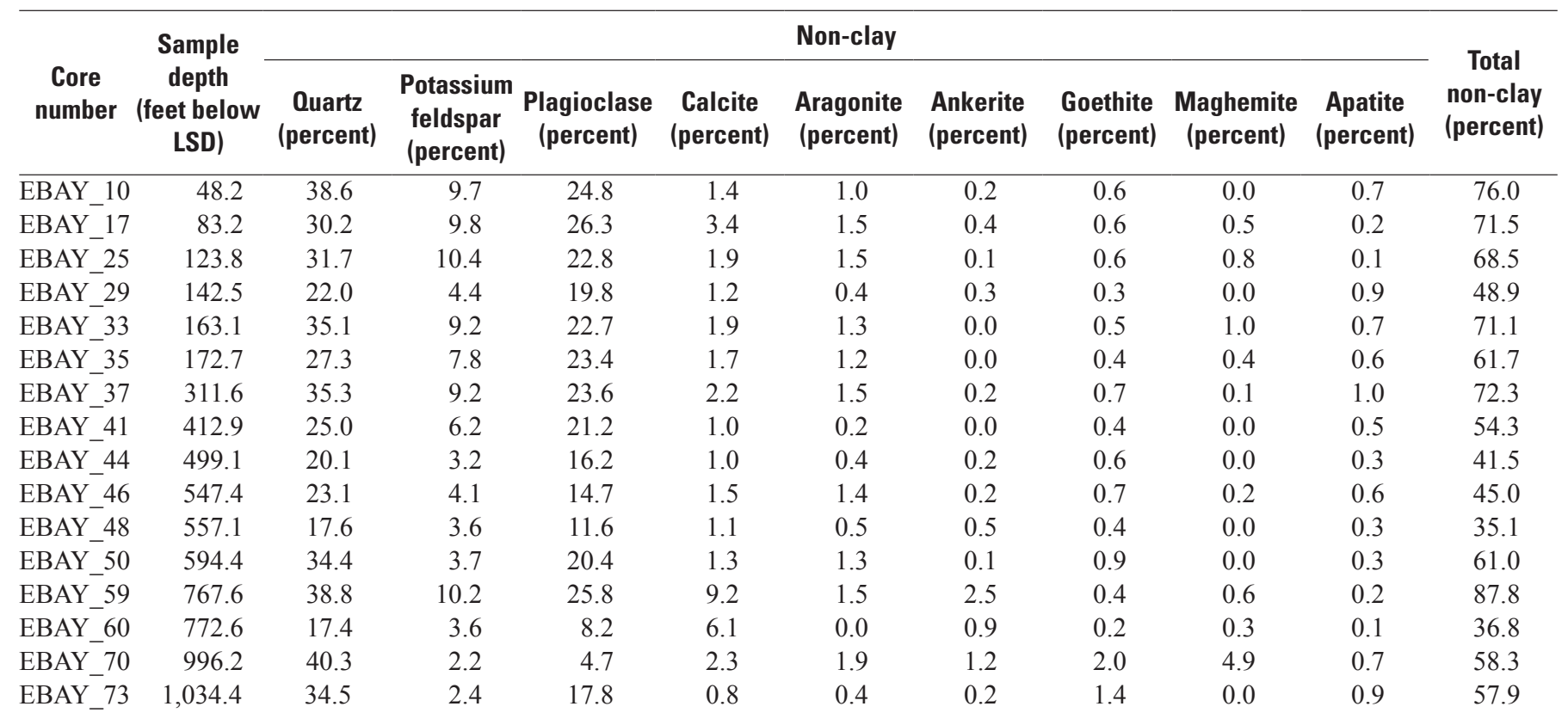


Table 17. Relative abundance of minerals determined from X-ray defraction analyses of core samples collected from the East Bay Bayside Monitoring Site (EBAY) borehole, San Lorenzo, California.-Continued

[Abbreviations: LSD, land surface datum]

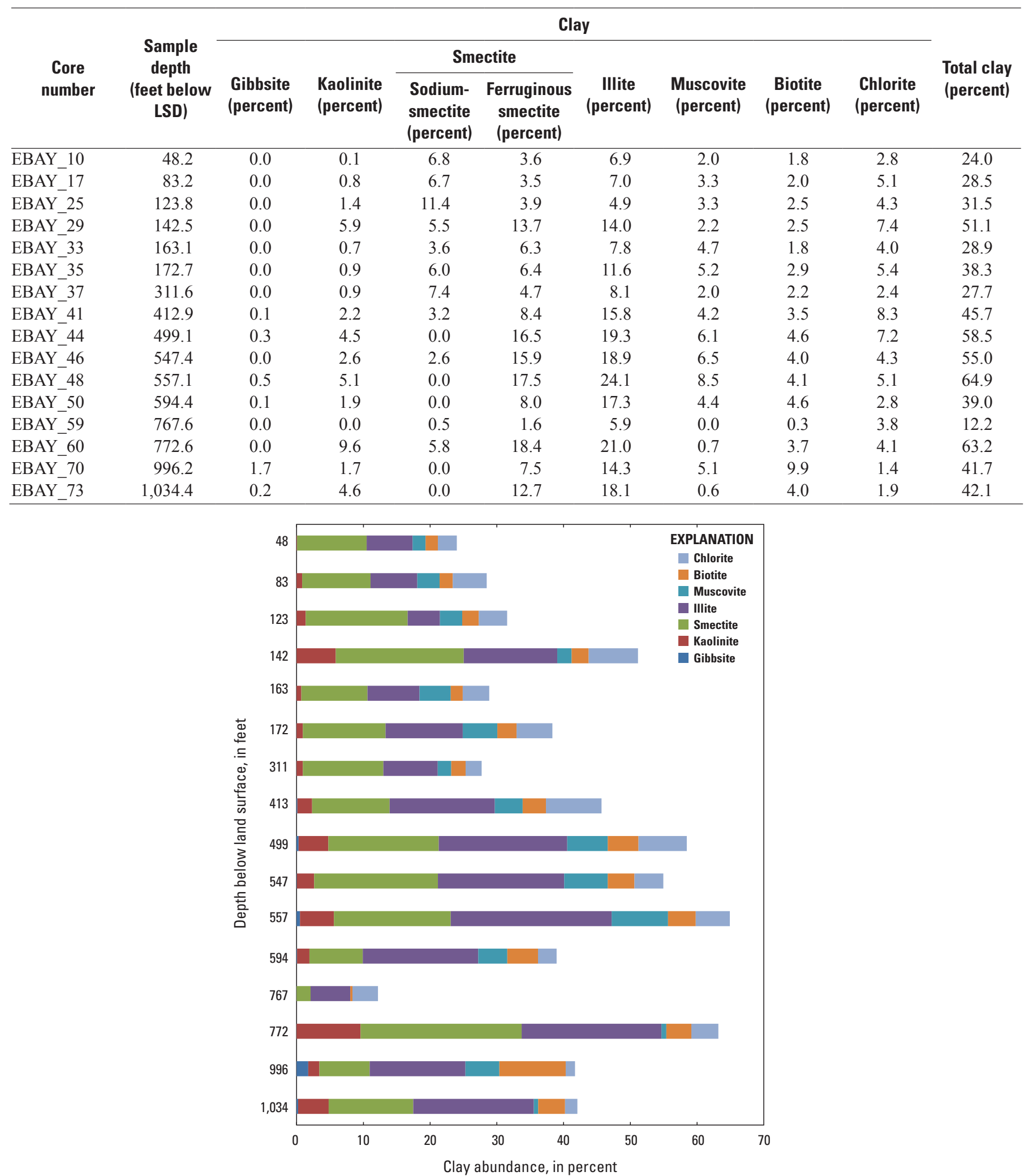

Figure 6. Graph showing rRelative clay abundance versus depth of core samples from East Bay Bayside monitoring site in San Lorenzo, California. 
The clay mineral, smectite, has low-layer charge and cations in only about a third of interlayer sites, which allows water to move in and out of the inter-clay layers, causing it to swell with the addition of water and shrink with the subtraction of water (Nesse, 2000). In addition, the swelling potential of smectite increases when monovalent cations sorb to the double layer (Hille, 1980). Compression and swell indexes from Lambe and Whitman (1969) describe the shrinkswell potential of smectite, illite, and kaolinite, depending upon the exchangeable cation between the tetrahedraloctahedral-tetrahedral layers. In general, divalent cations, such as calcium, magnesium, and iron, in the exchange complex reduce the swelling potential of montmorillonite, illite, and kaolanite (Lambe and Whitman, 1969; Hille, 1980). Trivalent aluminum at a low $\mathrm{pH}$ also reduces swelling potential, as does high salinity. If a salt-rich soil matrix is flushed with freshwater in the absence of calcium ions, however, the potential for swelling is high (Hille, 1980). Two types of smectite (sodium smectite and ferruginous smectite) were identified in the core samples; sodium smectite has a greater compression index than ferruginous smectite by a factor of 1.6 (Lambe and Whitman, 1969). The relative concentration of sodium smectite decreases with depth as ferruginous smectite increases in a one-to-one relation. The average percent weight of sodium smectite within the total weight percent of smectite was 29.2 percent, and ferruginous smectite composed 70.8 percent of the total smectite in all of the samples. Illite, because of its relatively high layer charge and the abundance of cations in the interlayer sites, does not have a great potential to swell when moistened (Nesse, 2000). Kaolanite has a low shrink-swell potential because weak electrostatic bonds yield a low cation exchange capacity; therefore, water molecules are not commonly found in the interlayer positions (Nesse, 2000). Amounts of illite and kaolanite did not follow a trend with depth.

Of the nine non-clay minerals identified by XRD, quartz and plagioclase were the most abundant, followed by lesser amounts of potassium feldspar, calcite, aragonite, goethite, maghemite, apatite, and ankerite (table 17). Clay percentages were inversely related to percentages of non-clay minerals.
The mineralogical composition of 17 core samples was determined by SEM/EDS (table 18). The SEM/EDS and XRD analyses identified 10 of the same minerals, the SEM/ EDS analysis exclusively identified 10 minerals, and the XRD analysis exclusively identified 4 minerals (table 19). The SEM/EDS analysis encountered difficulty identifying carbonate minerals because they occur as a fine intergrowth with clay minerals.

Framboidal pyrite, detected in EBAY_29, was the only secondary mineral observed by the SEM analysis. The presence of framboidal pyrite indicates that this sample was extracted from reducing conditions. In addition to framboidal pyrite, EBAY 29 contained the only organic matter observed (diatoms) in these core samples (table 18). The lack of organic matter in the other samples could be due to oxidation processes.

Iron oxide was observed on five samples, and manganese oxide possibly observed on one sample. It is unclear, however, if the presence of iron oxide was as a result of improper sample collection and storage techniques that allowed oxidation of the samples after collection.

The clay minerals primarily were composed of a mixture of illite and smectite. In addition to illite and smectite, distinct grains of biotite, chlorite, kaolanite, and muscovite were observed in the samples. The texture and morphologies of material in EBAY_65 indicated detrital origin.

Quartz and feldspar in the samples exhibited angular to sub-rounded morphology. These larger detrital grains also showed evidence of dissolution pitting.

The relative abundance of coarse or fine particles in samples identified by the XRD analysis were compared to SEM analysis results (table 20). Particle size from 7 of 17 samples was determined by using SEM. The relative abundance of coarse or fine particles, as measured by the XRD analysis, were not reflected in 57 percent of the grainsize analyses determined by using SEM. The inaccuracy of particle-size determination by SEM is attributed to flocculated clays and larger particles falling out of suspension during the grain-size analysis. 

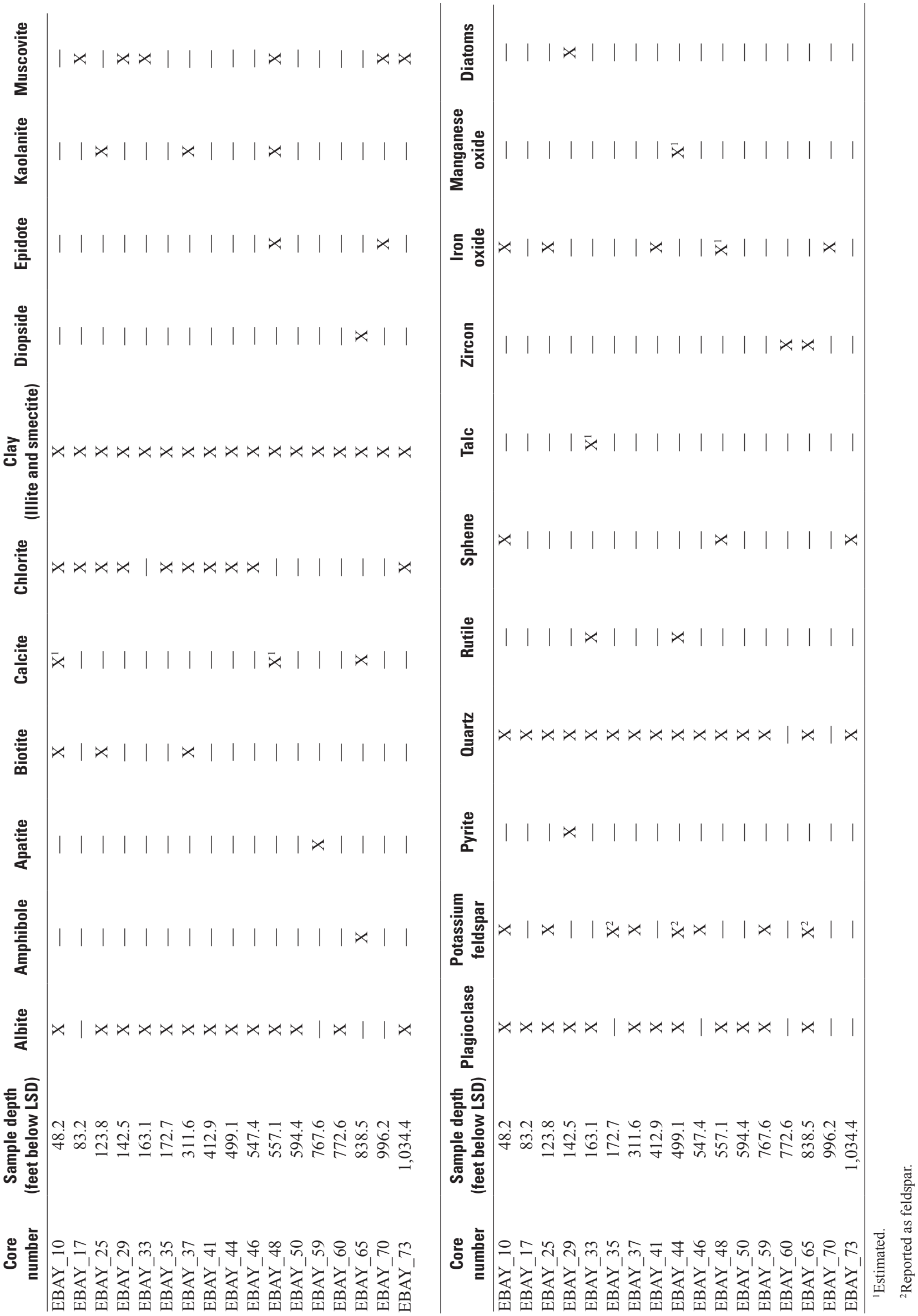
Table 19. Comparison between minerals detected by scanning electron microscope (SEM) and X-ray diffraction (XRD) from core samples collected from the East Bay Bayside Monitoring Site (EBAY) borehole, San Lorenzo, California.

[Abbreviations: X, detected; -, not detected]

\begin{tabular}{lcc}
\hline \multicolumn{1}{c}{ Mineral } & XRD & SEM \\
\hline Biotite & Clay & \\
Chlorite & $\mathrm{X}$ & $\mathrm{X}$ \\
Clay (illite and smectite) & $\mathrm{X}$ & $\mathrm{X}$ \\
Gibbsite & $\mathrm{X}$ & $\mathrm{X}$ \\
Kaolanite & $\mathrm{X}$ & - \\
Muscovite & $\mathrm{X}$ & $\mathrm{X}$ \\
Talc & $\mathrm{X}$ & $\mathrm{X}$ \\
& - & $\mathrm{X}$ \\
\hline Amphibole & Non-clay & \\
Apatite & - & $\mathrm{X}$ \\
Ankerite & $\mathrm{X}$ & $\mathrm{X}$ \\
Calcite & $\mathrm{X}$ & $\mathrm{X}$ \\
Diopside & $\mathrm{X}$ & $\mathrm{X}$ \\
Epidote & - & $\mathrm{X}$ \\
Goethite & - & - \\
Maghemite & $\mathrm{X}$ & $\mathrm{X}$ \\
Plagioclase (includes Albite) & $\mathrm{X}$ & $\mathrm{X}$ \\
Potassium feldspar & $\mathrm{X}$ & $\mathrm{X}$ \\
Pyrite & - & $\mathrm{X}$ \\
Quartz & $\mathrm{X}$ & $\mathrm{X}$ \\
Rutile & - & \\
Sphene & - & $\mathrm{X}$ \\
Zircon & - & \\
Iron oxide & & \\
Manganese oxide & - & $\mathrm{X}$ \\
\hline & & \\
\hline
\end{tabular}

\section{Elemental Composition}

Elemental composition of 17 cores samples was determined by using ICP-MS (table 21), and elemental composition of 9 core samples was determined by using INAA (table 22). Six samples (EBAY_10, EBAY_17, EBAY_25, EBAY_33, EBAY_35, and EBAY_37) were analyzed by using both methods; 19 element determinations were common to both analyses (table 23). The coefficient of determination $\left(\mathrm{R}^{2}\right)$, a measure of the agreement between the data and a linear regression, was used to compare the results from the ICP-MS and from the INAA analyses. The average $\mathrm{R}^{2}$ value of 0.687 and median $\mathrm{R}^{2}$ value of 0.799 indicated a relatively strong overall correlation for results derived from the two methods (table 23). $\mathrm{R}^{2}$ values of 11 elements were equal to or greater than the median, indicating a strong correlation; 4 elements had $\mathrm{R}^{2}$ values between the median and mean, indicating reasonable correlation; and 4 elements had low $\mathrm{R}^{2}$ values, indicating a weak or poor correlation (table 23). Because the ICP-MS analysis was applied to more samples than the INAA
Table 20. Comparison between relative grain sizes detected by scanning electron microscope (SEM) and X-ray diffraction (XRD) analyses of core samples collected from the East Bay Bayside Monitoring Site (EBAY) borehole, San Lorenzo, California.

[Abbreviations: LSD, land surface datum; NA, information not available; $\mathrm{X}$, indicates greater percentage of coarse or fine grains; *, not sufficiently determined by particle size analysis; >, greater than, - , no data]

\begin{tabular}{|c|c|c|c|c|c|}
\hline \multirow[b]{2}{*}{$\begin{array}{c}\text { Core } \\
\text { number }\end{array}$} & \multirow{2}{*}{$\begin{array}{c}\text { Sample } \\
\text { depth } \\
\text { (ft below } \\
\text { LSD) }\end{array}$} & \multicolumn{2}{|c|}{ SEM } & \multicolumn{2}{|c|}{ XRD } \\
\hline & & $\begin{array}{c}\text { Coarse } \\
\text { (percent) }\end{array}$ & $\begin{array}{c}\text { Fine } \\
\text { (percent) }\end{array}$ & $\begin{array}{c}\text { Coarse } \\
\text { (>50 } \\
\text { percent) }\end{array}$ & $\begin{array}{c}\text { Fine } \\
\text { (>50 } \\
\text { percent) }\end{array}$ \\
\hline EBAY_10 & 48.2 & $*$ & * & $\mathrm{X}$ & - \\
\hline EBAY 17 & 83.2 & * & * & $\mathrm{X}$ & - \\
\hline EBAY_ 25 & 123.8 & - & $\mathrm{X}$ & $\mathrm{X}$ & - \\
\hline EBAY 29 & 142.5 & - & $\mathrm{X}$ & - & $\mathrm{X}$ \\
\hline EBAY 33 & 163.1 & * & * & $\mathrm{X}$ & - \\
\hline EBAY_35 & 172.7 & * & * & $\mathrm{X}$ & - \\
\hline EBAY_37 & 311.6 & $\mathrm{X}$ & - & $\mathrm{X}$ & - \\
\hline EBAY_41 & 412.9 & * & * & $\mathrm{X}$ & - \\
\hline EBAY 44 & 499.1 & * & * & - & $\mathrm{X}$ \\
\hline EBAY 46 & 547.4 & $\mathrm{X}$ & - & - & $\mathrm{X}$ \\
\hline EBAY_48 & 557.1 & - & $\mathrm{X}$ & - & $\mathrm{X}$ \\
\hline EBAY_50 & 594.4 & * & * & $\mathrm{X}$ & - \\
\hline EBAY_59 & 767.6 & - & $\mathrm{X}$ & $\mathrm{X}$ & - \\
\hline EBAY_60 & 772.6 & * & * & - & $\mathrm{X}$ \\
\hline EBAY 65 & 838.5 & * & * & NA & NA \\
\hline EBAY_70 & 996.2 & * & * & $X$ & - \\
\hline EBAY_73 & 1034.4 & - & $\mathrm{X}$ & $\mathrm{X}$ & - \\
\hline
\end{tabular}

analysis, the following discussion focuses on results from the ICP-MS analyses.

Comparison of major and trace elements to depth, revealed patterns common among the 37 elements analyzed by ICP-MS. Concentrations by depth showed a similar pattern in 26 of the 37 elements analyzed, which are italicized in table 21. Examples of this pattern are shown for zinc, scandium, and iron in figure 7 . These 26 elements generally exhibited relatively high concentrations at the depths of 142 , 499,557 , and $773 \mathrm{ft}$; had relatively low concentrations at depths of 48, 312, 768, and $838 \mathrm{ft}$; and showed a noticeable increase in concentration from 768 fbls to 773 fbls (table 21, fig. 7). Included in this group were cadmium and lead, which differed from this pattern in only the shallowest two samples. A different pattern emerged among calcium, sodium, strontium, and phosphorus, which showed a noticeable decrease in concentration from $768 \mathrm{fbls}$ to $773 \mathrm{fbls}$. Calcium and phosphorous were similar, having higher concentrations at depths of 83 and $768 \mathrm{ft}$ and lower concentrations at depths of $48,124,163,594$, and $1,034 \mathrm{ft}$. 


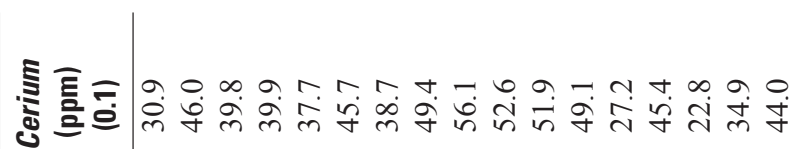

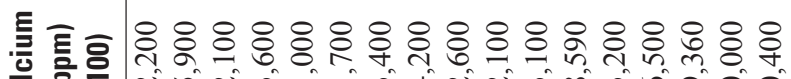

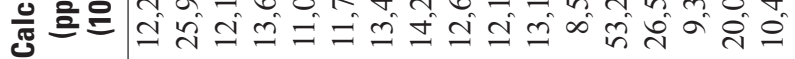

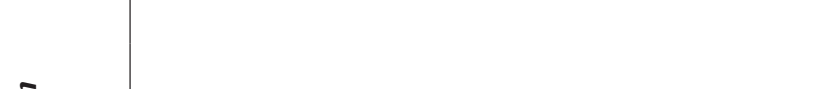

产言产兽

禀

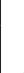

言言晋 产言兽

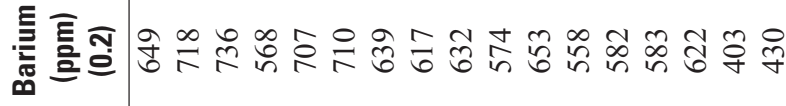

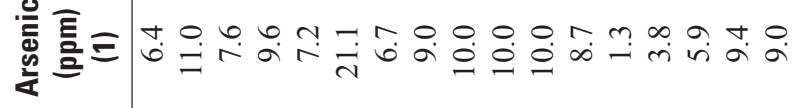

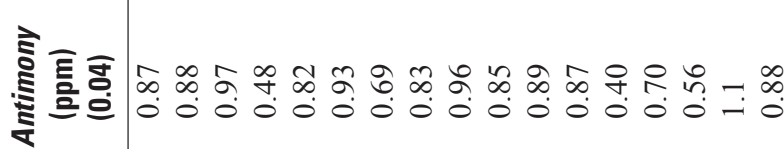

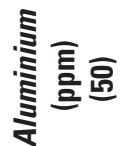

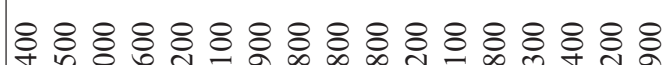

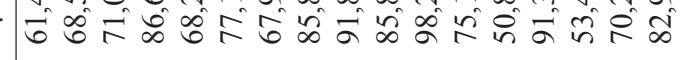

\section{吾 \\ 这 离} क

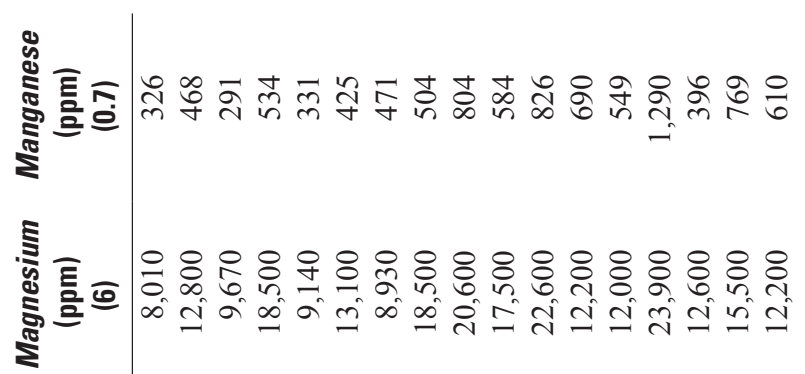

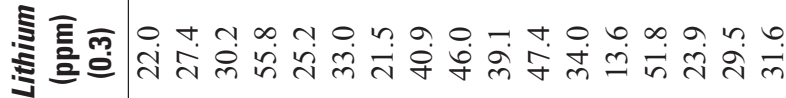

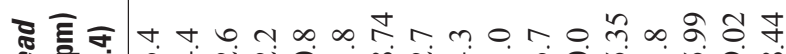

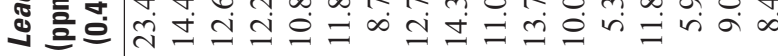

产

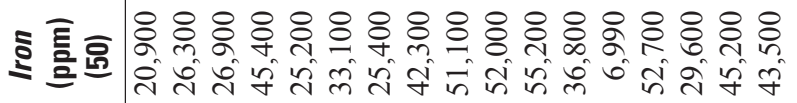

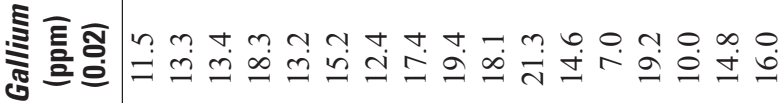

产言恶

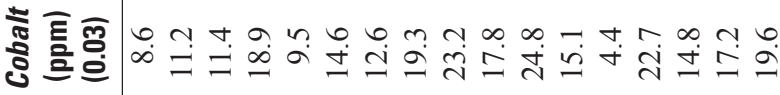

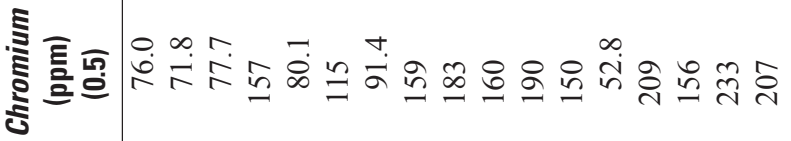

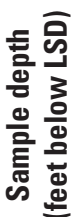

4

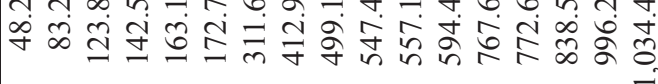

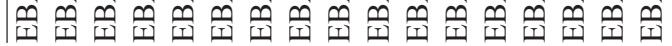

兽

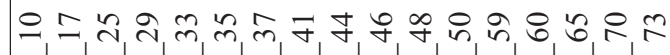

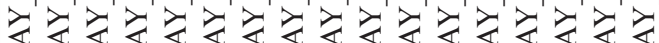

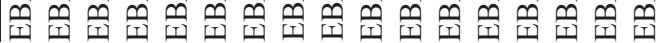




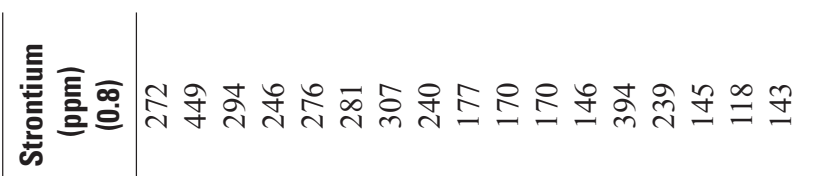

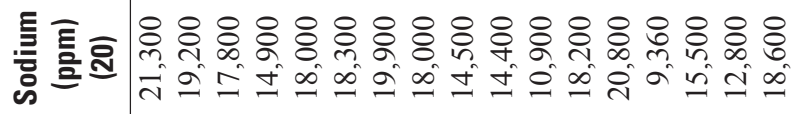

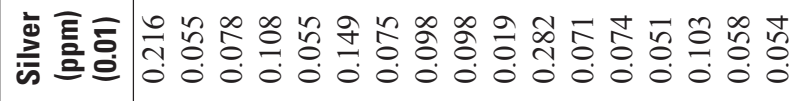

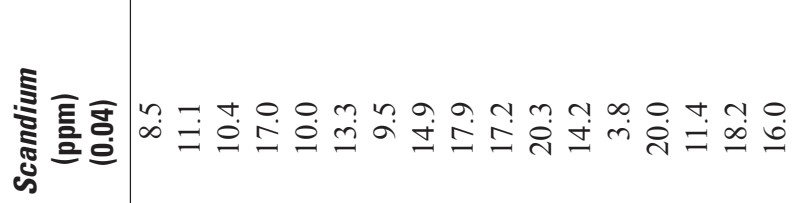

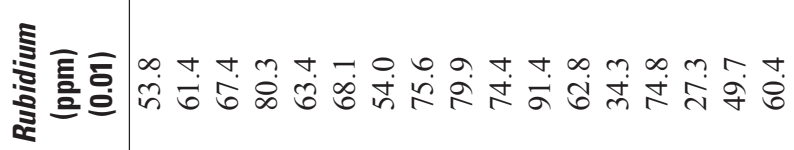

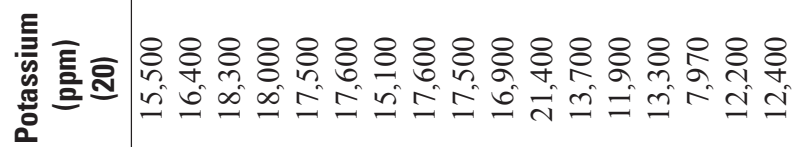

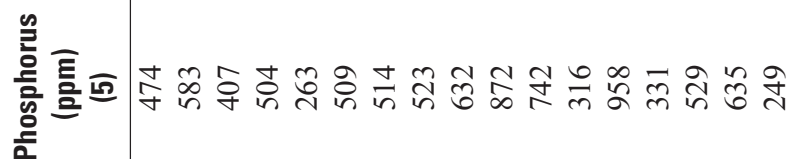

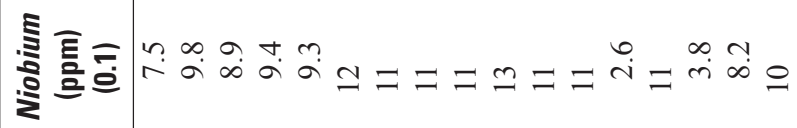

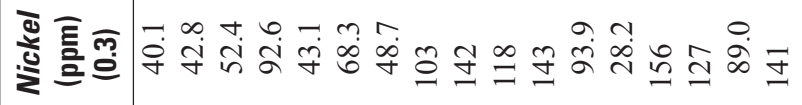

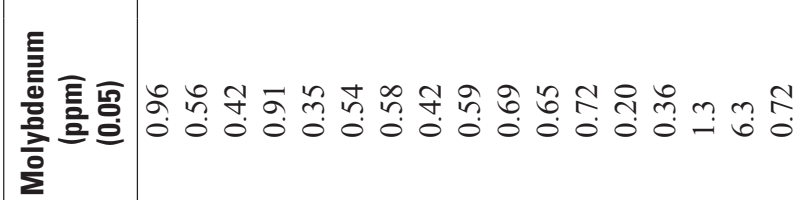

흥

흥

高

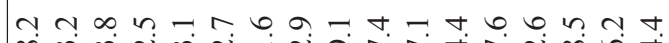

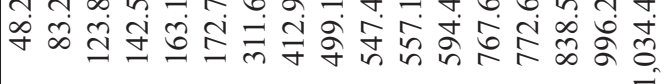

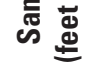
苍 离

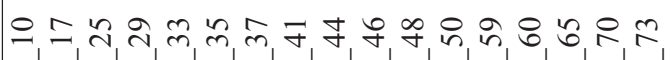

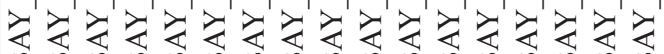

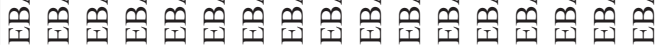

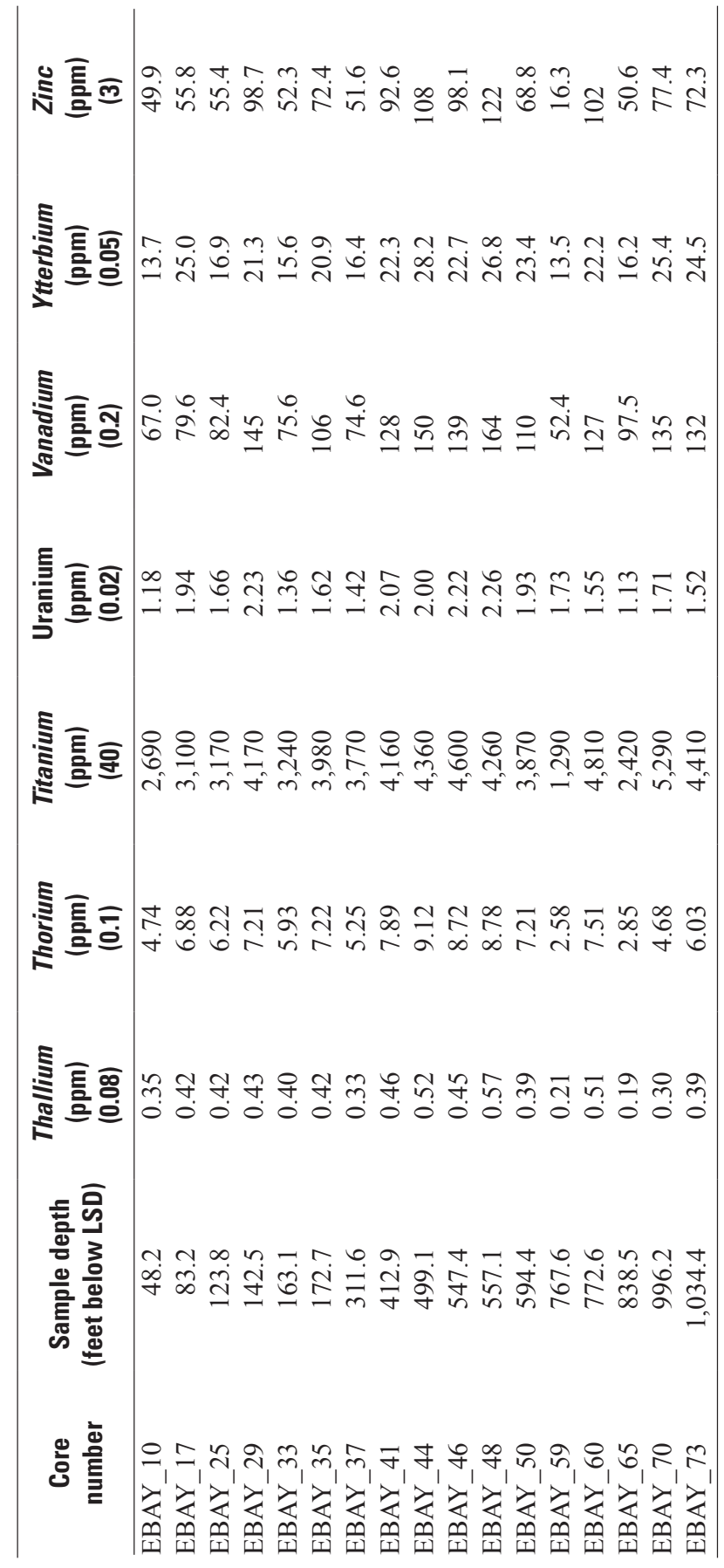



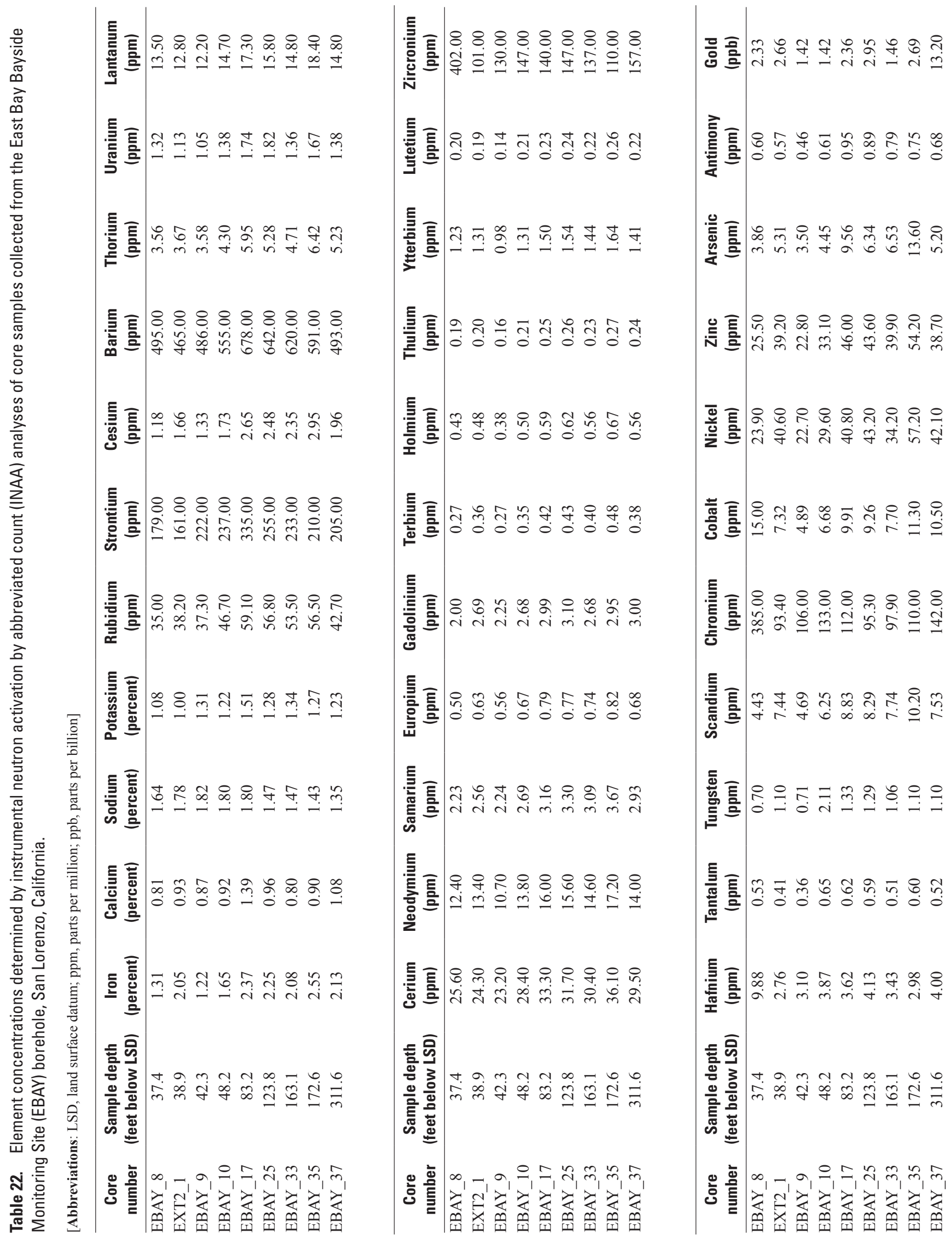


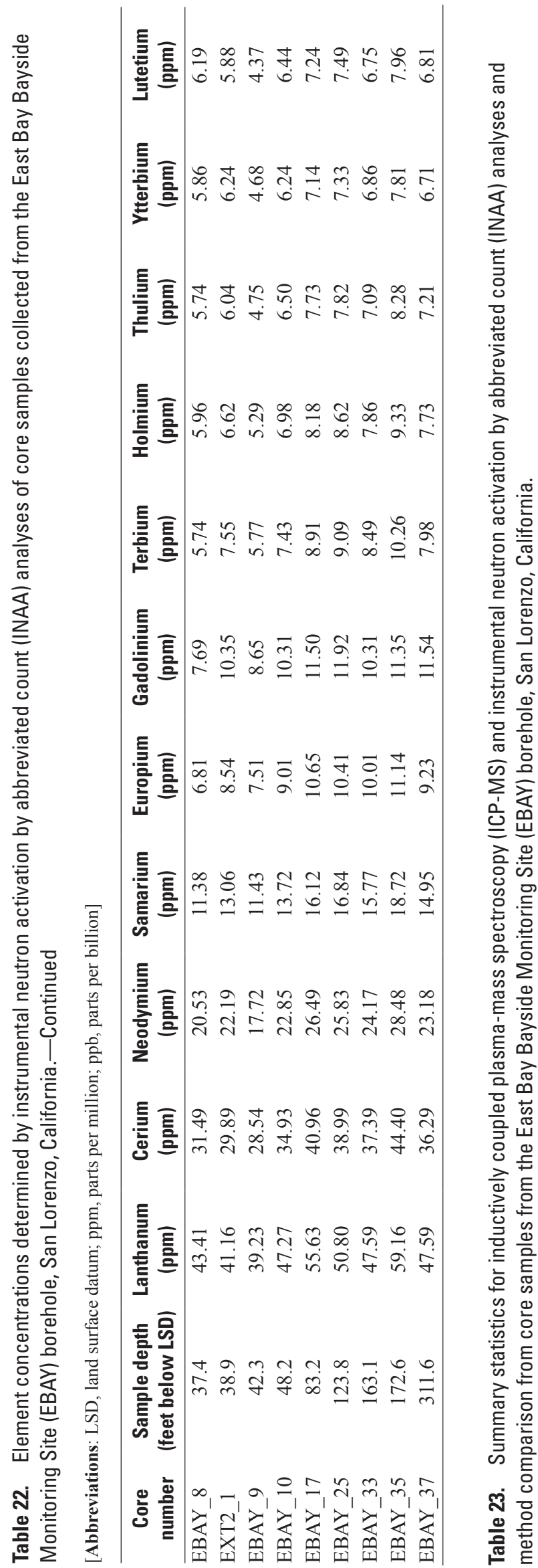

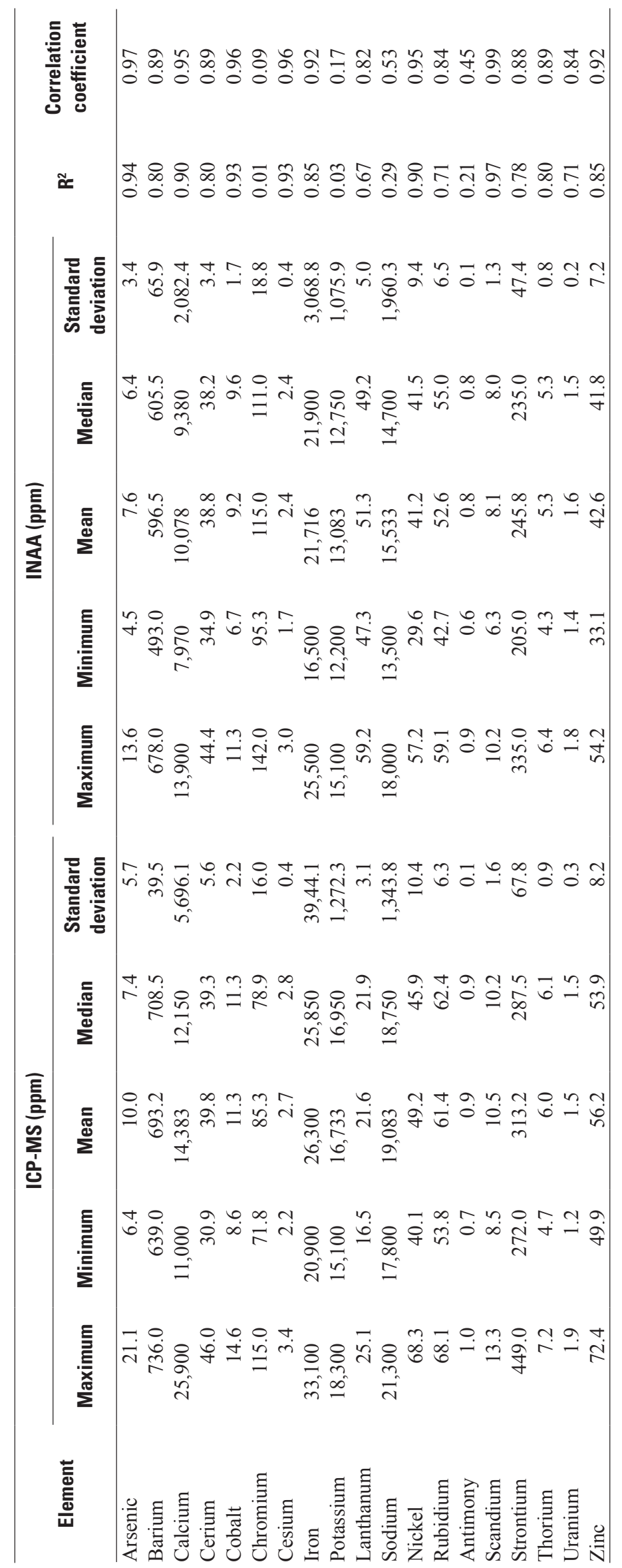




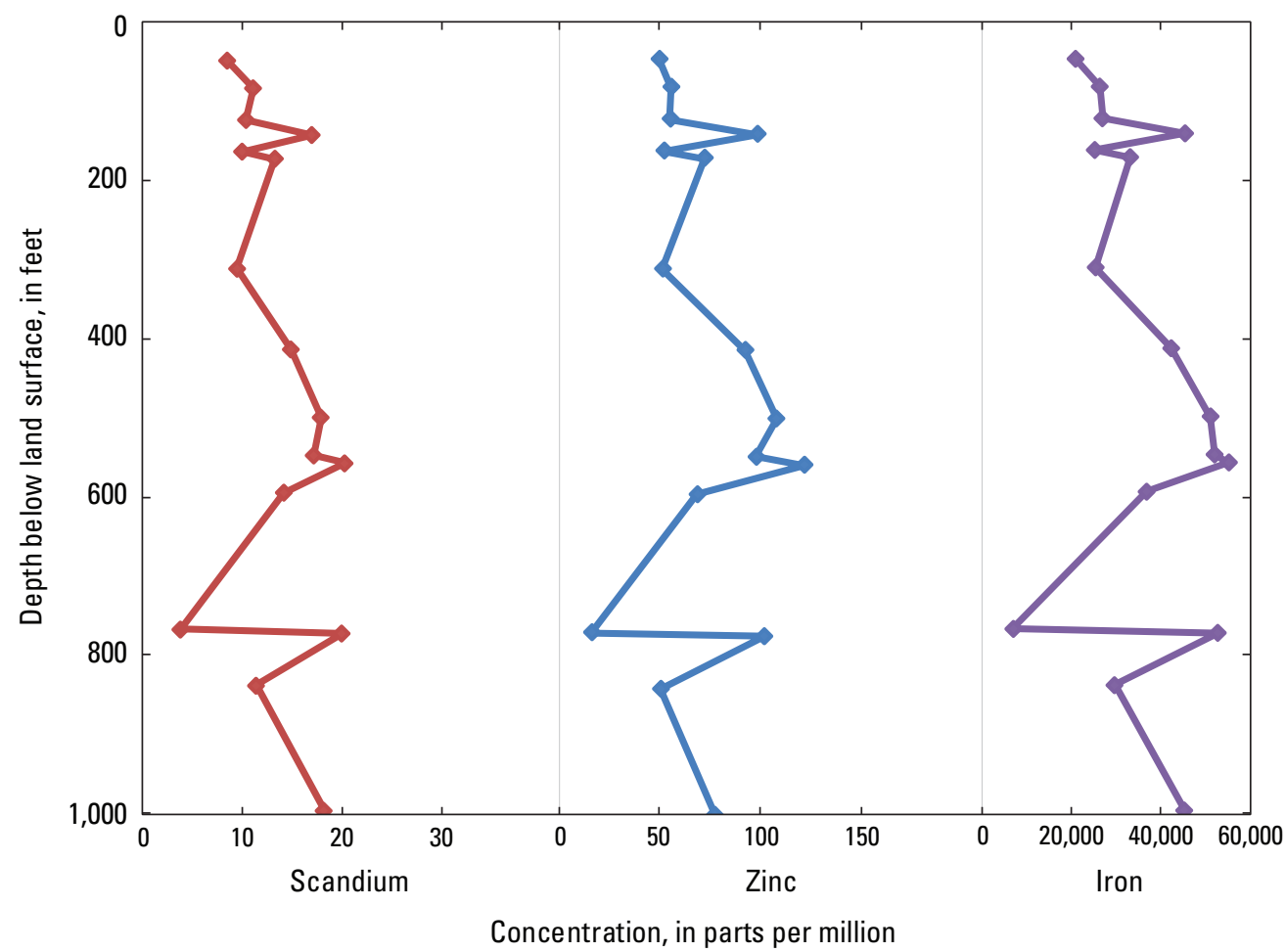

Figure 7. Example of elements, scandium, zinc, and iron, in core samples from the East Bay Bayside Monitoring Site (EBAY) borehole, showing similar patterns in concentration at depth below land surface in feet.

Sodium (with the exception of the decreasing relative concentrations between the depths of 767 and $772 \mathrm{ft}$ ) exhibited a pattern that mirrored that of calcium and phosphorus. There were relatively high concentrations of sodium at the same depths where calcium and phosphorus were in low concentrations. No depth-related patterns in concentration were apparent for 7 of the 37 elements, including silver, arsenic, barium, bismuth, potassium, molybdenum, and uranium.

\section{Pore-Water Chemistry}

The results from the analyses of 20 EBAY pore-water samples for $\mathrm{pH}$, salinity, major ions, trace metals, stable isotopes of hydrogen and oxygen, DIC, and alkalinity are presented in tables 24 through 27. Comparisons between samples of the pore-water analyzed from the EBAY core and the groundwater analyzed from the EBAY piezometers showed similar concentrations for several constituents. Waterquality indicators, $\mathrm{pH}$ and alkalinity, are shown in figure 8; major ions and trace elements are shown in figures 9 and 10 , respectively. In these figures, pore-water results are presented as points along a line, and groundwater results are represented as points corresponding to the center of the screened interval from which the sample was collected. Gaps in the graphical representation of pore-water represent missing data points. For example, pore-water samples were analyzed for bromide at depths of 655,762 , and $771 \mathrm{fbls}$, but calcium was not analyzed at $762 \mathrm{fbls}$ and, therefore, has a missing datum point.
Alkalinity, in milligrams per liter as calcium carbonate

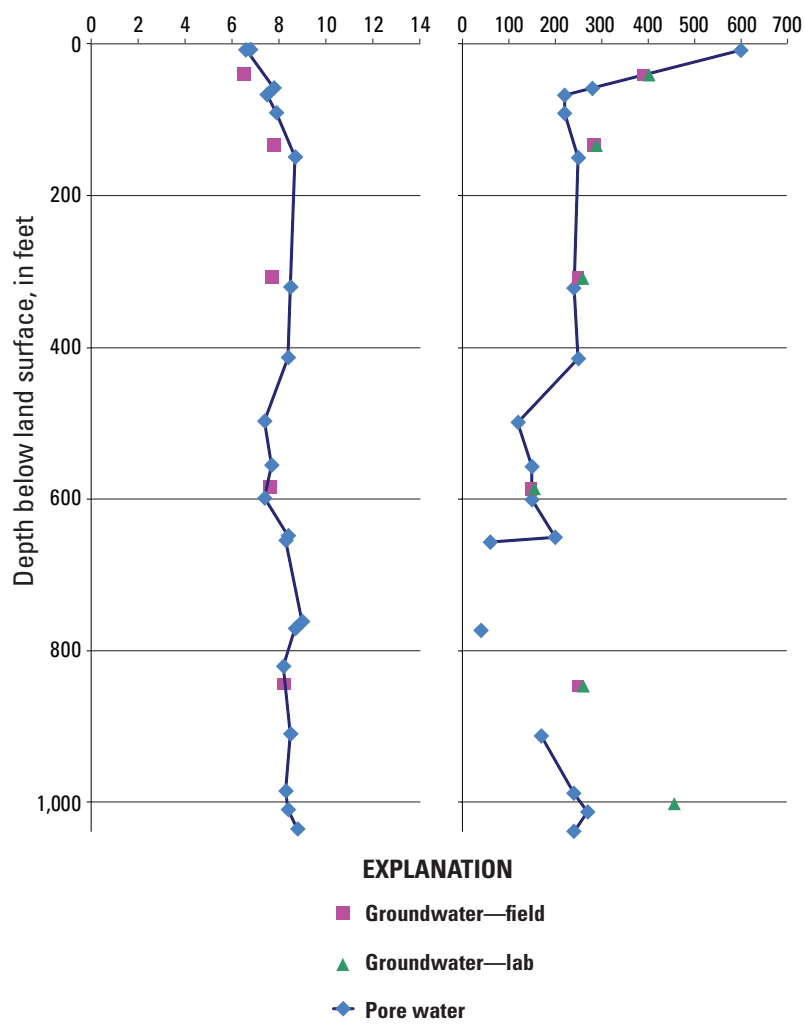

Figure 8. Graph showing cComparison of the water-quality indicators $\mathrm{pH}$ and alkalinity between pore water and groundwater from the East Bay Bayside Monitoring Site (EBAY) core and EBAY piezometers, respectively. 

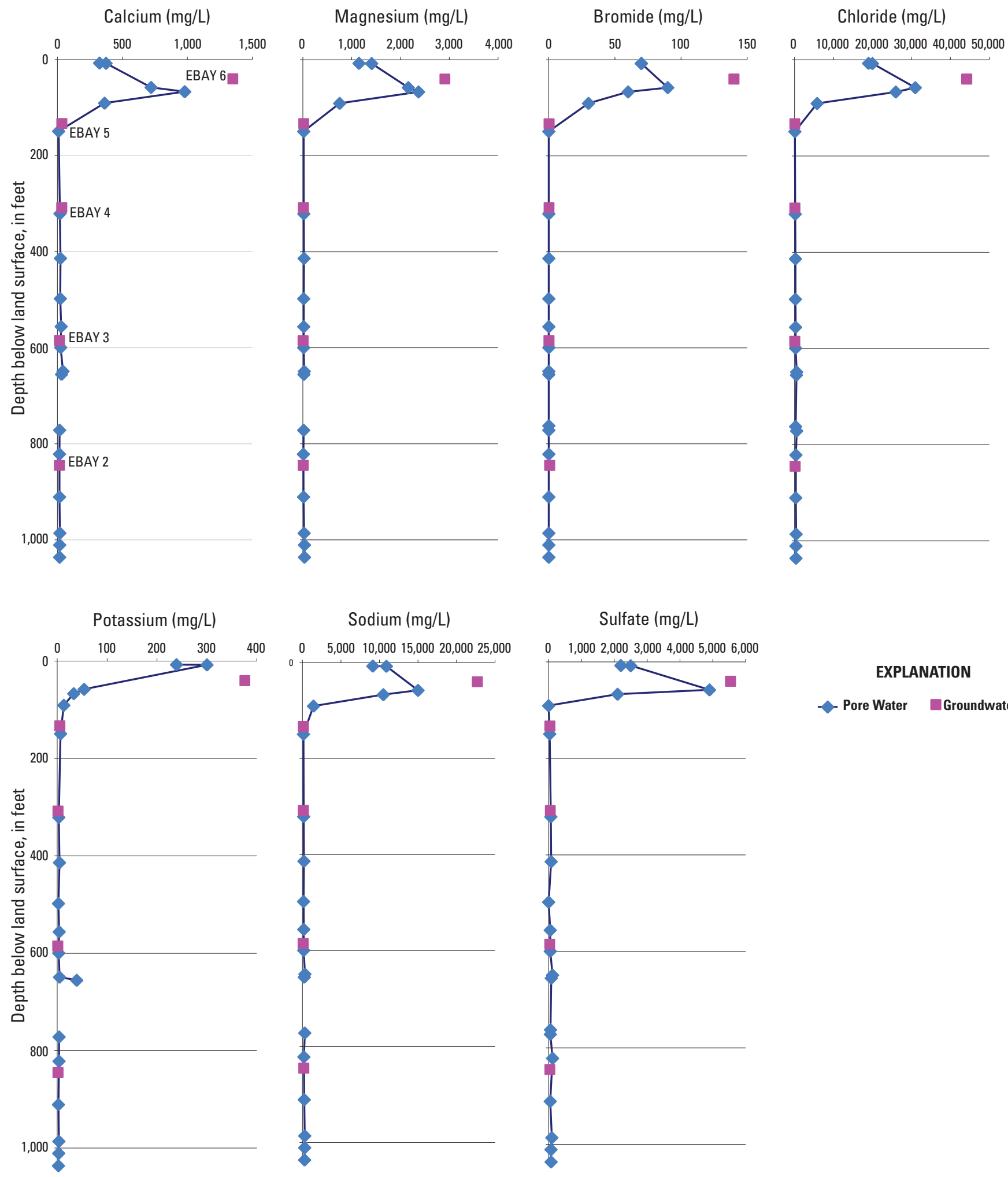

Figure 9. Graphs showing cComparison of selected major-ion concentrations between pore water and groundwater from the East Bay Bayside Monitoring Site (EBAY) core and EBAY piezometers, respectively. 

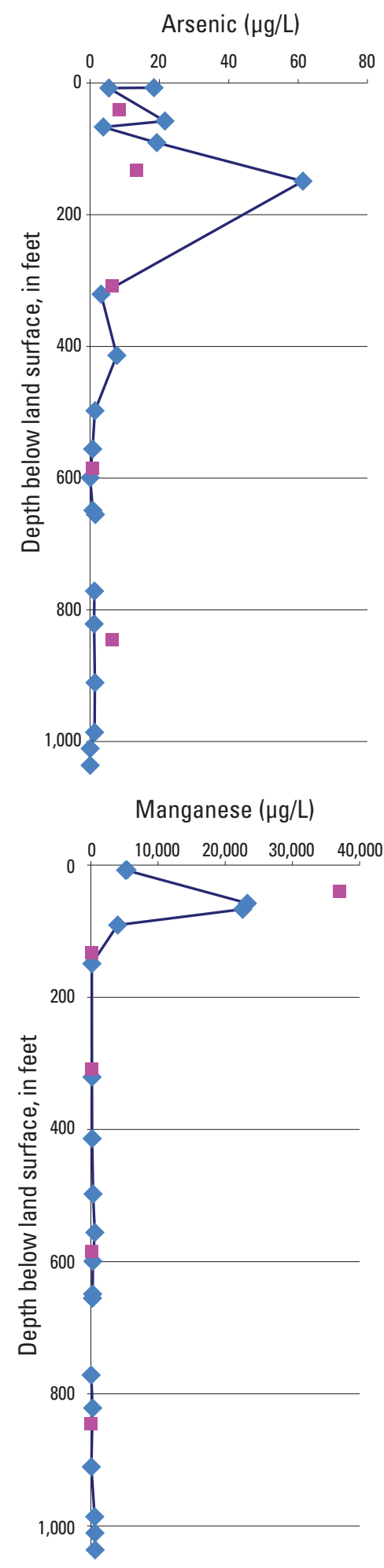

Barium $(\mu \mathrm{g} / \mathrm{L})$

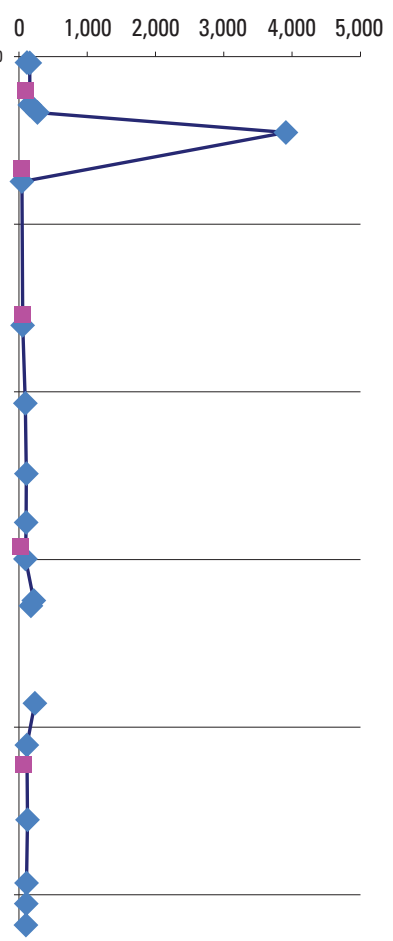

Strontium $(\mu \mathrm{g} / \mathrm{L})$

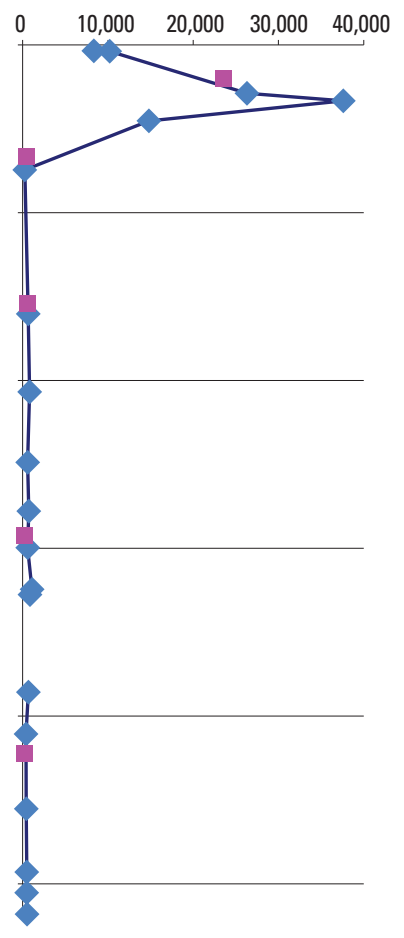

Boron ( $\mu \mathrm{g} / \mathrm{L})$

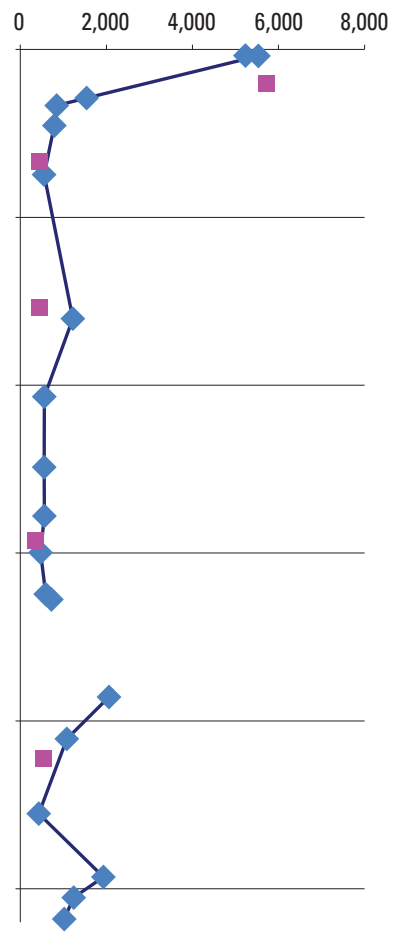

Uranium ( $\mu \mathrm{g} / \mathrm{L})$

Iron ( $\mu \mathrm{g} / \mathrm{L})$
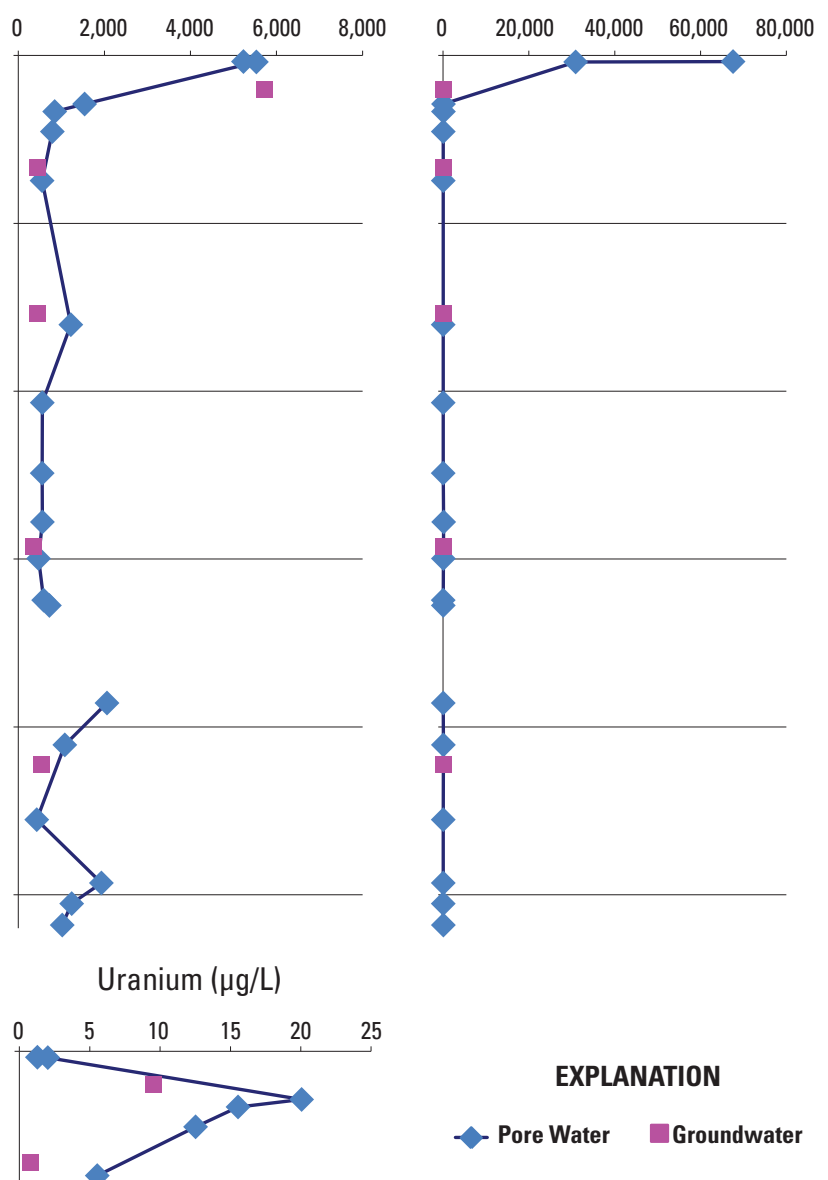

Figure 10. Graphs showing cComparison of selected trace-metal concentrations between pore water and groundwater from the East Bay Bayside Monitoring Site (EBAY) core and EBAY piezometers, respectively. 
Sample depth and selected water-quality indicators $(\mathrm{pH}$, salinity, and alkalinity), and dissolved inorganic carbon (DIC) in pore-water are presented in table 24. Values of $\mathrm{pH}$ ranged from 6.6 to 9.0 and had a mean and median of 8.1 and 8.35 , respectively. The two shallowest of the 20 samples (within $8 \mathrm{ft}$ of land surface) were circumneutral, having a $\mathrm{pH}$ of around 7 , whereas the remaining 18 samples were more basic. Porewater samples ranged in salinity from 0.05 to 4.4 percent and showed a marked drop in salinity below $67 \mathrm{fbls}$. Alkalinity, as calculated from DIC, ranged from 40 to $600 \mathrm{mg} / \mathrm{L}$ as calcium carbonate and had an average concentration of about $220 \mathrm{mg} / \mathrm{L}$. DIC was detected in all of the pore-water samples. Concentrations of DIC ranged from about 9 to $215 \mathrm{mg} / \mathrm{L}$ and averaged about $57 \mathrm{mg} / \mathrm{L}$. Comparison of $\mathrm{pH}$ and alkalinity results between groundwater and pore-water from the EBAY piezometers and cores showed similar patterns with depth (fig. 8).

Pore-water samples were analyzed for 12 major ions (table 25). Of the major ions, four cations (calcium,

Table 24. Summary of water quality indicators, alkalinity, and dissolved inorganic carbon for pore water extracted from selected East Bay Bayside Monitoring Site (EBAY) core.

[The five digit number in parentheses below the constituent name is the U.S. Geological Survey (USGS) parameter code used to uniquely identify a specific constituent or property. Abbreviations: $\mathrm{CaCO}_{3}$, calcium carbonate; $\mathrm{ft}$, feet; LSD, land surface datum; mg/L, milligrams per liter; $\mathrm{NaCl}$, sodium chloride; - , not collected]

\begin{tabular}{|c|c|c|c|c|c|}
\hline \multirow[b]{2}{*}{$\begin{array}{c}\text { Core } \\
\text { number }\end{array}$} & \multirow{2}{*}{$\begin{array}{c}\text { Sample } \\
\text { depth } \\
\text { (ft below } \\
\text { LSD) }\end{array}$} & \multicolumn{3}{|c|}{$\begin{array}{c}\text { Water-quality } \\
\text { indicators }\end{array}$} & \multirow{2}{*}{$\begin{array}{c}\text { Dissolved } \\
\text { inorganic } \\
\text { carbon } \\
\text { (mg/L) } \\
\text { (00691) }\end{array}$} \\
\hline & & $\begin{array}{c}\text { pH } \\
\text { (standard } \\
\text { units) } \\
(00400)\end{array}$ & $\begin{array}{c}\text { Salinity } \\
\text { (percent } \\
\mathrm{NaCl} \text { ) }\end{array}$ & $\begin{array}{c}\text { Alkalinity } \\
\text { (mg/L as } \\
\mathrm{CaCO}_{3} \text { ) }\end{array}$ & \\
\hline$\overline{\text { EBAY_2 }}$ & 7.2 & 6.8 & 2.94 & - & - \\
\hline EBAY_2 & 7.6 & 6.6 & 3.2 & 600 & 215 \\
\hline EBAY_12 & 57.8 & 7.8 & 4.4 & 280 & 70.5 \\
\hline EBAY_14 & 66.8 & 7.5 & 3.5 & 220 & 57.0 \\
\hline EBAY_19 & 90.6 & 7.9 & 0.91 & 220 & 54.1 \\
\hline EBAY_30 & 149.1 & 8.7 & 0.05 & 250 & 60.0 \\
\hline EBAY_39 & 320.7 & 8.5 & 0.07 & 240 & 56.7 \\
\hline EBAY_41 & 413.6 & 8.4 & 0.1 & 250 & 59.0 \\
\hline EBAY_44 & 497.6 & 7.4 & 0.07 & 120 & 30.3 \\
\hline EBAY_48 & 555.8 & 7.7 & 0.14 & 150 & 37.9 \\
\hline EBAY_51 & 599.4 & 7.4 & 0.14 & 150 & 37.8 \\
\hline EBAY_54 & 648.9 & 8.4 & 0.17 & 200 & 48.4 \\
\hline EBAY_56 & 655.3 & 8.3 & 0.13 & 60 & 14.2 \\
\hline EBAY_58 & 762.3 & 9.0 & 0.17 & - & - \\
\hline EBAY_60 & 771.5 & 8.7 & 0.14 & 40 & 8.9 \\
\hline EBAY_62 & 821.4 & 8.2 & 0.11 & - & - \\
\hline EBAY_66 & 910.5 & 8.5 & 0.13 & 170 & 41.7 \\
\hline EBAY_68 & 986.0 & 8.3 & 0.19 & 240 & 58.4 \\
\hline EBAY_71 & $1,010.6$ & 8.4 & 0.19 & 270 & 63.7 \\
\hline EBAY 74 & $1,036.1$ & 8.8 & 0.15 & 240 & 57.4 \\
\hline
\end{tabular}

magnesium, potassium, and sodium) and three anions (bromine, chloride, and iodine) were detected at all depths sampled. Sulfate was detected in 90 percent of the samples and had concentrations ranging from 33 to $4900 \mathrm{mg} / \mathrm{L}$. Nitrate was detected in 50 percent of the samples and had concentrations ranging from about 1 to $3 \mathrm{mg} / \mathrm{L}$. Bromide was detected only in samples collected within $91 \mathrm{ft}$ of land surface, and concentrations ranged from 30 to $90 \mathrm{mg} / \mathrm{L}$. Nitrite was detected only in the sample collected from $414 \mathrm{fbls}$. Orthophosphate was not detected in any of the samples.

Seven of these ions (calcium, magnesium, bromide, chloride, potassium, sodium, and sulfate) were analyzed in both pore-water and groundwater ( fig. 9). Groundwater and pore-water sampled from EBAY piezometers and cores, respectively, showed similar patterns in concentration with increasing depth for these seven constituents. Bromide in pore-water was not detected deeper than $91 \mathrm{fbls}$, but was detected in all piezometer depths sampled at Bayside.

Pore-water samples were analyzed for eight trace metals (table 26). In all samples analyzed, the trace metals barium, boron, iron, manganese, and strontium were detected and ranged in concentration from about 45 to $3,910 \mu \mathrm{g} / \mathrm{L}, 429$ to $5,530 \mu \mathrm{g} / \mathrm{L}, 16$ to $67,600 \mu \mathrm{g} / \mathrm{L}, 26$ to $23,300 \mu \mathrm{g} / \mathrm{L}$, and 240 to $37,600 \mu \mathrm{g} / \mathrm{L}$, respectively. Arsenic was detected in 84 percent of the samples and had concentrations ranging from 0.73 to $61.4 \mu \mathrm{g} / \mathrm{L}$. Uranium was detected in 95 percent of the samples and had concentrations ranging from 1.18 to $20.06 \mu \mathrm{g} / \mathrm{L}$. Lead was not detected in any of the samples. As with major ions, the highest trace metal concentrations were generally within $91 \mathrm{ft}$ of land surface.

Pore-water and groundwater samples from EBAY core and piezometers, respectively, were compared for eight of the same trace elements (tables 9 and 26), and the results generally agree (fig. 10). Results showed higher concentrations at shallower depths in both groundwater and pore-water samples. Lead was not detected in either pore-water or groundwater samples. Iron was detected in only 69 percent of the groundwater samples, whereas it was detected in all of the pore-water samples; concentrations of iron in porewater samples were 3 to 10 times higher than in groundwater samples.

The isotopic ratios of oxygen and hydrogen in water can be used as tracers of hydrologic processes. These ratios aid in interpretation of the source of groundwater recharge because they reflect the altitude, latitude, and temperature of precipitation as well as the extent of evaporation of the water (Clark and Fritz, 1997; Kendall and McDonnell, 1998). Groundwater samples collected from EBAY piezometers showed similar isotopic ratios for hydrogen and oxygen to the pore-water samples collected from the EBAY core at similar depths (tables 10 and 27; fig. 5). The one exception to this was a groundwater sample collected from the EBAY3 piezometer situated at a depth of $585 \mathrm{fbls}$, which showed an isotopic ratio of hydrogen and oxygen lighter than its pore-water counterparts at similar depths. 


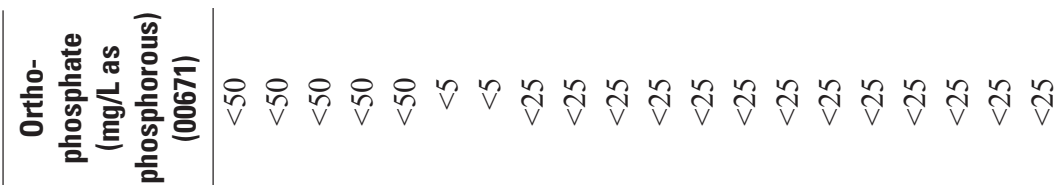

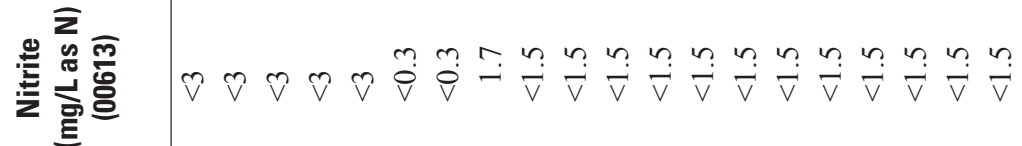

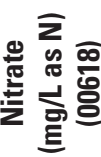

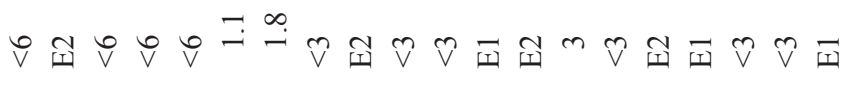

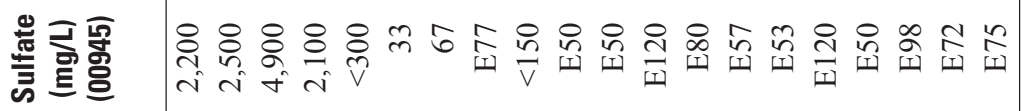

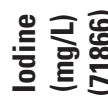

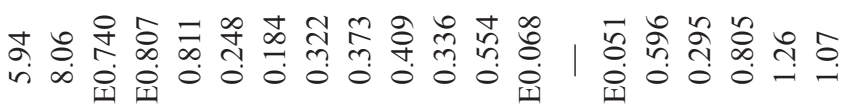

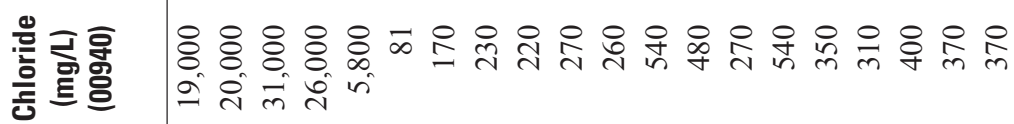

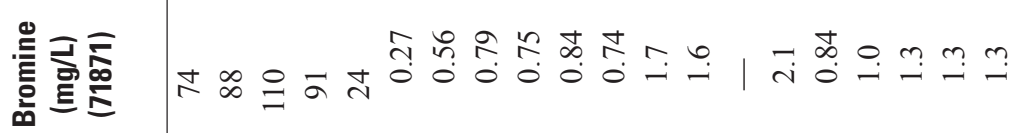

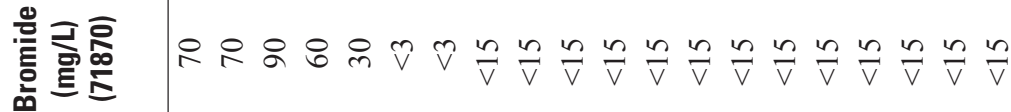

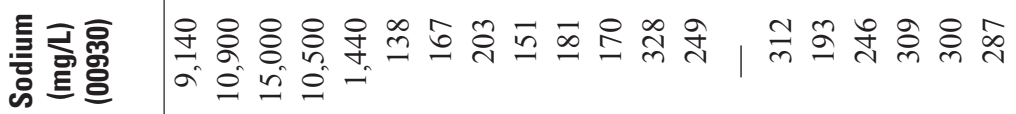

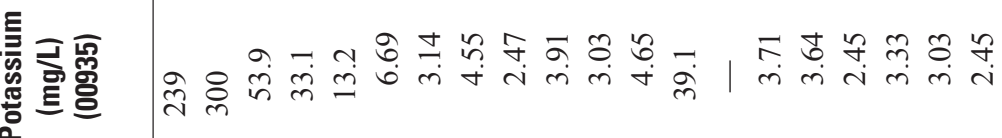

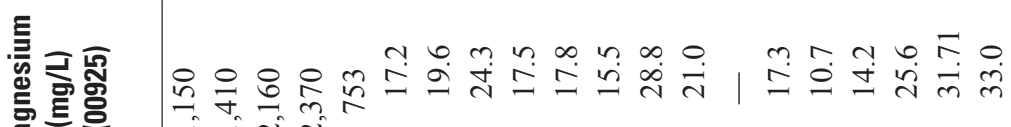

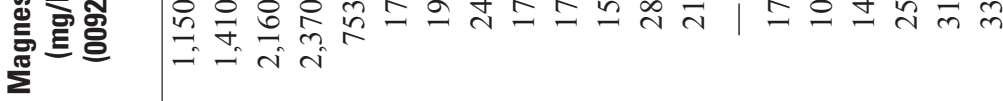

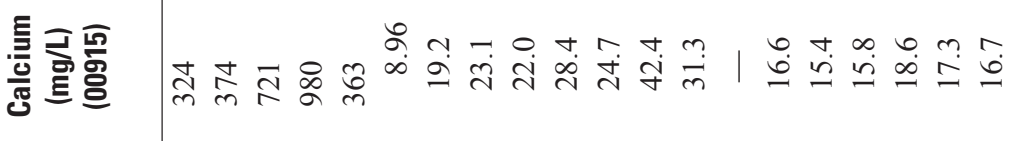

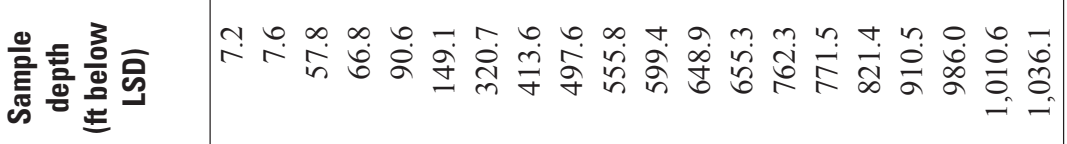
仓ั้

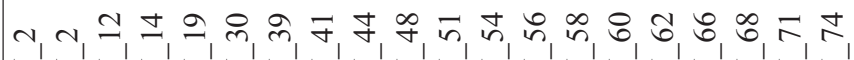

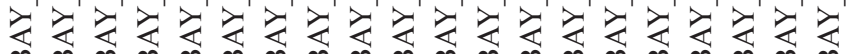

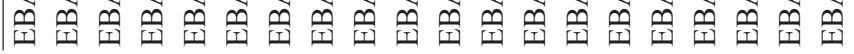


Table 26. Trace metals in pore water extracted from selected East Bay Bayside Monitoring Site (EBAY) core and analyzed by the U.S. Geological Survey (USGS) National Water Quality Laboratory, Denver, Colorado.

[The five digit number in parentheses below the constituent name is the USGS parameter code used to uniquely identify a specific constituent or property. Abbreviations: E, estimated value; LSD, land surface datum; $\mu \mathrm{g} / \mathrm{L}$, microgram per liter; $<$, less than minimum detection limit; - , not collected]

\begin{tabular}{|c|c|c|c|c|c|c|c|c|c|}
\hline \multirow[b]{2}{*}{$\begin{array}{c}\text { Core } \\
\text { number }\end{array}$} & \multirow[b]{2}{*}{$\begin{array}{l}\text { Sample depth } \\
\text { (feet below } \\
\text { LSD) }\end{array}$} & \multicolumn{8}{|c|}{ Trace metals } \\
\hline & & $\begin{array}{c}\text { Arsenic } \\
(\mu \mathrm{g} / \mathrm{L}) \\
(01000)\end{array}$ & $\begin{array}{c}\text { Barium } \\
\text { ( } \mu \mathrm{g} / \mathrm{L}) \\
(01005)\end{array}$ & $\begin{array}{c}\text { Boron } \\
(\mu g / L) \\
(01020)\end{array}$ & $\begin{array}{c}\text { Iron } \\
\text { (pg/L) } \\
(01046)\end{array}$ & $\begin{array}{c}\text { Lead } \\
\text { ( } \mu \mathrm{g} / \mathrm{L}) \\
(01049)\end{array}$ & $\begin{array}{c}\text { Manganese } \\
(\mu \mathrm{g} / \mathrm{L}) \\
(01056)\end{array}$ & $\begin{array}{c}\text { Strontium } \\
(\mu \mathrm{g} / \mathrm{L}) \\
(01080)\end{array}$ & $\begin{array}{c}\text { Uranium } \\
\text { ( } \mu \mathrm{g} / \mathrm{L}) \\
(22703)\end{array}$ \\
\hline$\overline{\text { EBAY_2 }}$ & 7.2 & 18.4 & 119 & E5,230 & 67,600 & $<1.6$ & 5,360 & 8,340 & 1.27 \\
\hline EBAY_2 & 7.6 & 5.4 & 160 & E5,530 & 30,900 & $<1.6$ & 5,160 & 10,200 & 2.01 \\
\hline EBAY_12 & 57.8 & 21.6 & 160 & 1,540 & 91.3 & $<2.4$ & 23,300 & 26,300 & 20.06 \\
\hline EBAY_19 & 90.6 & 19.2 & 3,910 & 791 & 38.5 & $<0.8$ & 3,980 & 14,800 & 12.52 \\
\hline EBAY_30 & 149.1 & 61.4 & 45 & 552 & E36.5 & $<1.6$ & 140 & 240 & 5.53 \\
\hline EBAY_39 & 320.7 & 3.2 & 56 & 1,220 & E17.5 & $<0.8$ & 160 & 648 & 5.21 \\
\hline EBAY_41 & 413.6 & 7.7 & 96 & 557 & 21.7 & $<0.8$ & 183 & 817 & 8.25 \\
\hline EBAY_44 & 497.6 & 1.4 & 111 & 555 & E15.9 & $<0.8$ & 306 & 583 & 1.18 \\
\hline EBAY_58 & 762.3 & - & - & - & - & - & - & - & - \\
\hline EBAY_60 & 771.5 & E1.25 & 235 & 2,060 & E32.8 & $<1.6$ & 26.3 & 666 & $<0.8$ \\
\hline EBAY_62 & 821.4 & E1.15 & 117 & 1,080 & 58.8 & $<0.8$ & 254 & 387 & 1.21 \\
\hline EBAY_66 & 910.5 & E1.39 & 127 & 429 & E27.5 & $<1.6$ & 54.1 & 420 & 4.62 \\
\hline EBAY_68 & 986.0 & E1.28 & 113 & 1,930 & E31.9 & $<1.6$ & 557 & 472 & 4.08 \\
\hline EBAY_71 & $1,010.6$ & $<2.4$ & 109 & 1,240 & E28.7 & $<1.6$ & 583 & 463 & 6.25 \\
\hline EBAY_74 & $1,036.1$ & $<2.4$ & 104 & 1,020 & 53.5 & $<1.6$ & 619 & 506 & 5.05 \\
\hline
\end{tabular}

Table 27. Stable isotope ratios of hydrogen and oxygen in pore water extracted from selected East Bay Bayside Monitoring Site (EBAY) core and analyzed by U.S. Geological Survey-National Research Program (USGS-NRP), Stable Isotope Laboratory, Reston, Virginia.

[The five digit number in parentheses below the constituent name is the U.S. Geological Survey parameter code used to uniquely identify a specific constituent or property. Stable isotope ratios are reported in the standard delta notation $(\delta)$, the ratio of a heavier isotope to the more common lighter isotope of that element, relative to a standard reference material. Abbreviations: ft, feet; LSD, land surface datum; H, hydrogen; O, oxygen]

\begin{tabular}{|c|c|c|c|c|c|c|c|}
\hline \multirow[b]{2}{*}{$\begin{array}{c}\text { Core } \\
\text { number }\end{array}$} & \multirow{2}{*}{$\begin{array}{c}\text { Sample } \\
\text { depth } \\
\text { (ft below } \\
\text { LSD) }\end{array}$} & \multicolumn{2}{|c|}{ Stable isotopes } & \multirow[b]{2}{*}{$\begin{array}{c}\text { Core } \\
\text { number }\end{array}$} & \multirow{2}{*}{$\begin{array}{c}\text { Sample } \\
\text { depth } \\
\text { (ft below } \\
\text { LSD) }\end{array}$} & \multicolumn{2}{|c|}{ Stable isotopes } \\
\hline & & $\begin{array}{c}\delta^{2} \mathrm{H} \text { of water } \\
\text { (per mil) } \\
\text { (82082) }\end{array}$ & $\begin{array}{c}\boldsymbol{\delta}^{18} 0 \text { of water } \\
\text { (per mil) } \\
(82085)\end{array}$ & & & $\begin{array}{c}\delta^{2} \mathrm{H} \text { of water } \\
\text { (per mil) } \\
\text { (82082) }\end{array}$ & $\begin{array}{c}\delta^{18} 0 \text { of water } \\
\text { (per mil) } \\
\text { (82085) }\end{array}$ \\
\hline$\overline{\text { EBAY_2 }}$ & 7.2 & -29.3 & -5.16 & EBAY_51 & 599.4 & $\begin{array}{l}-50.2 \\
\end{array}$ & $\begin{array}{l}-7.33 \\
\end{array}$ \\
\hline EBAY 2 & 7.6 & -28.2 & -3.7 & EBAY 54 & 648.9 & -53.7 & -7.48 \\
\hline EBAY_12 & 57.8 & -21.6 & -2.41 & EBAY_56 & 655.3 & -50.3 & -7.14 \\
\hline EBAY_14 & 66.8 & -27.2 & -3.35 & EBAY_58 & 762.3 & -52 & -7.18 \\
\hline EBAY_19 & 90.6 & -40.7 & -5.88 & EBAY_60 & 771.5 & -53.2 & -7.43 \\
\hline EBAY_30 & 149.1 & -39.2 & -5.94 & EBAY_62 & 821.4 & -51.6 & -7.57 \\
\hline EBAY_39 & 320.7 & -47.1 & -6.96 & EBAY_66 & 910.5 & -53.1 & -7.75 \\
\hline EBAY_41 & 413.6 & -51.9 & -7.13 & EBAY_68 & 986.0 & -51.5 & -7.4 \\
\hline EBAY_44 & 497.6 & -49.3 & -7.27 & EBAY_71 & $1,010.6$ & -49.7 & -7.28 \\
\hline EBAY_48 & 555.8 & -49.8 & -7.18 & EBAY_74 & $1,036.1$ & -48.5 & -7.22 \\
\hline
\end{tabular}




\section{Summary}

Aquifer-system deformation associated with groundwater-level changes was investigated cooperatively by the USGS and the EBMUD at the BGP, in San Lorenzo, California, where managed aquifer storage and recovery is planned. Water from this source can be used to help meet short-term needs arising from drought or seismic and other water-supply emergencies, or imported water can be injected, stored, and later recovered for public supply. This investigation focused on collecting and analyzing subsurface data obtained during and after drilling at four sites at and near the BGP.

Fourteen piezometers and two extensometers were installed among six boreholes at the four sites. Drill cuttings were collected and described, and a suite of borehole geophysical logs was made in each borehole. At the Bayside site, next to the BGP, samples from selected sections of core were analyzed to determine pore-water chemistry, vertical hydraulic conductivity, physical and mechanical properties, depositional environment, age determinations, and mineral composition. Groundwater samples were collected from all 14 piezometers for water-quality analyses. Groundwater-level and aquifer-system-compaction measurements were made at the Bayside site, and slug tests were performed at the Bayside piezometers and nine pre-existing sites to determine aquifer characteristics.

The lithologic and geophysical logs compiled for this study indicated unconsolidated to partially consolidated continental and marine alluvial deposits consisting of mostly silt and clay. Shear wave velocities in the upper $100 \mathrm{ft}$ indicated a stiff soil. A laterally extensive zone, consisting of three coarse sand and gravel beds $98 \mathrm{ft}$ thick, in total, between 508 and $650 \mathrm{fbls}$, known as the Deep aquifer, is the focus of this ASR project.

Groundwater levels monitored in the piezometers at the EBAY site exhibited diurnal fluctuations. Groundwater levels measured in piezometer EBAY3, screened within the Deep aquifer, exhibited the greatest diurnal fluctuation. Groundwater levels measured in piezometers EBAY3, EBAY4, and EBAY5 exhibited seasonal fluctuations where groundwater levels were higher in the winter and spring and lower in the summer and fall. Seasonal fluctuations were not apparent in groundwater levels measured in EBAY2 and EBAY6.

Aquifer-system compaction and expansion in the shallow and deep extensometers corresponded to groundwaterlevel drawdown and recovery, respectively. The connection between compaction and expansion of the aquifer system and drawdown and recovery of groundwater levels was demonstrated by diurnal and seasonal fluctuations in the extensometer data. In addition, the magnitude of the values of compaction and expansion between the shallow and deep extensometers was similar, indicating that the deformation was occurring above the shallow extensometer.

Slug test estimates of hydraulic conductivity of the hydrogeologic units next to the screened zones, performed at 14 sites, ranged from 0.34 to $120 \mathrm{ft} / \mathrm{d}$. A hydraulic conductivity of $32 \mathrm{ft} / \mathrm{d}$, estimated at EBAY3, was the highest conductivity estimated from the piezometers at the EBAY site.

Groundwater-quality results summarized here focus on the noteworthy attributes associated with the Deep aquifer. Groundwater samples collected from piezometer EBAY3, situated in the Deep aquifer, exhibited the lowest concentrations of water-quality indicators for specific conductance and alkalinity and had a non-detect for dissolved oxygen. Nutrient concentrations in the Deep aquifer were the lowest among the EBAY piezometers for nitrogen (non-detect) and orthophosphate as phosphorous. In addition, EBAY3 stood out as the only piezometer with a detection for nitrate plus nitrite. Major and minor ion concentrations were the lowest in groundwater samples from EBAY3 for calcium, magnesium, potassium, bromide, chloride, sulfate, and total dissolved solids. In addition, groundwater samples from EBAY3 exhibited the lowest trace-metal concentrations of aluminum, arsenic, barium, cadmium, copper, lithium, strontium, and uranium. Stable-isotope values from groundwater samples from EBAY3 exhibited a low ratio. Tritium values were generally elevated compared to the remaining samples.

Analysis of core samples collected for the Bayside site revealed sediments are normally consolidated below a depth of about $135 \mathrm{ft}$. They showed greater elastic specific storage and less inelastic specific storage than samples collected from the San Joaquin Valley. Mineralogical analysis of two core samples within the Deep aquifer zone showed an abundance of total clay consisting mainly of smectite and illite. Elemental analysis showed relatively high concentrations of major and trace elements within the Deep aquifer zone. The analysis of pore-water chemistry demonstrated a decrease in salinity and ion concentration below $90 \mathrm{ft}$. Results from the analysis of the pore-water chemistry also revealed elevated concentrations of iron and magnesium in the Deep aquifer zone. The data derived from the extensive analyses can be used by EBMUD and other agencies to evaluate the chemical and mechanical responses of aquifers underlying the East Bay Plain to the injection and recovery of imported water from the Sierra Nevada of California. 


\section{References Cited}

Aitken, M.J., 1998, An introduction to optical dating: The dating of Quaternary sediments by the use of photonstimulated luminescence: New York, Oxford University Press, $267 \mathrm{p}$.

American Society for Testing and Materials, 2003, Standard test methods for measurement of hydraulic conductivity of saturated porous materials using a flexible wall permeameter, D5084-03: West Conshohocken, Penn., ASTM International, DOI: 10.1520/D5084-00R03, www.astm.org.

Anderson, C.W., 2005, Turbidity (version 2.1): U.S. Geological Survey Techniques of Water-Resources Investigations, book 9, chap. A6., section 6.7, accessed September 30, 2009, http://pubs.water.usgs.gov/twri9A6/.

Arnal, R.E., Quinterno, P.J., Conomos, T.J., and Gram, R., 1980, Trends in the distribution of recent foraminifera in San Francisco Bay, in Sliter, W.V., ed., Studies in marine micropaleontology and paleoecology. A memorial volume to Orville L. Bandy: Cushman Foundation for Foraminiferal Research Special Publication 19, p. 17-39.

Atwater, B.G., Ross, B.E., Wehmiller, J.F., 1981, Stratigraphy of the late Quaternary estuarine deposits and amino acid stereochemistry of oyster shells beneath San Francisco Bay, California: Quaternary Research, v. 16, p. 181-200, http://dx.doi.org/10.1016/0033-5894(81)90044-2.

Battarbee, R.A., 1986, Diatom analysis, in Berglund, B.E., ed., Handbook of holocene palaeoecology and palaeohydrology: New York, John Wiley \& Sons, p. 527-570.

Bennett, M.J., Sneed, M., Noce, T.E., and Tinsley, J. III, 2009, Cone penetration test and soil boring at the Bayside Groundwater Project Site in San Lorenzo, Alameda County, California: U.S. Geological Survey Open-File Report 2009-1050, 30 p., http://pubs.er.usgs.gov/publication/ofr20091050.

Brocher, T.M., Borchers J.W., Sneed, M., and Tinsley, J.C., 2007, New 300-m deep vs suspension log helps characterize seismic hazards posed by the San Leandro Basin, East Bay, Northern California: Seismological Research Letters, v. 78, no. 2, p. 270-271.

Brown and Caldwell, Inc., 1986, Evaluation of groundwater resources and proposed design for emergency water supply wells: Pleasant Hill, California, [variously paged].

Budahn, J.R., and Wandless, G.A., 2002, Instrumental neutron activation by abbreviated count: Chapter Y, U.S. Geological Survey Open-File Report 02-233-Y, http://pubs.usgs.gov/ of/2002/ofr-02-0223/Y15INAA-SHORT_M.pdf.
Butler, J.J., Jr., and Garnett, E.J., 2000, Simple procedures for analysis of slug tests in formations of high hydraulic conductivity using spreadsheet and scientific graphics software: Kansas Geological Survey Open-File Report 2000-40, 21 p., http://www.kgs.ku.edu/Hydro/ Publications/OFR00_40/index.html.

Casagrande, A., 1936, The determination of the preconsolidation load and its practical significance in $\mathrm{A}$. Casagrande, ed., Proceeding of the $1^{\text {st }}$ International Soil Mechanics and Foundation Engineering Conference, Cambridge, Mass., June 22-26, 1936: Harvard University, Cambridge, Mass., Graduate School of Engineering, v. 3, p. 60-64.

Castagna, J.P, Batzle, M.L., and Eastwood, R.L., 1985, Relationships between compressional-wave and shear-wave velocities in clastic silicate rocks: Geophysics, v. 50, no. 4, p. 571-581, http://dx.doi.org/10.1190/1.1441933.

Catchings, R.D., Borchers, J.W., Goldman, M.R., Gandhok, G., Ponce, D.A., and Steedman, C.E., 2006, Subsurface structure of the East Bay Plain ground-water basin: San Francisco Bay to the Hayward fault, Alameda County, California: U.S. Geological Survey Open-File Report 2006-1084, 68 p., http://pubs.er.usgs.gov/publication/ofr 20061084.

CH2M-Hill, Inc., 2000, Regional hydrogeologic investigation of the south East Bay Plain, Oakland, Calif., [variously paged].

Clark, I.D., and Fritz, P., 1997, Environmental isotopes in hydrogeology: Boca Raton, CRC Press, 328 p.

Connor, C.L., 1975, Holocene sedimentation history of Richardson Bay, California: Stanford, Calif., Stanford University, M.S. thesis, $112 \mathrm{p}$.

Coplen, T.B., Wildman, J.D., and Chen, J., 1991, Improvements in the gaseous hydrogen-water equilibraton technique for hydrogen isotope ratio analysis: Analytical Chemistry, v. 63, no. 9, p. 910-912.

Cumming, B.F., Wilson, S.E., Hall, R.J., and Smol, J.P., 1995, Diatoms from British Columbia (Canada) lakes and their relationship to salinity, nutrients and other limnological variables: Bibliotheca Diatomologica, v. 31, 207 p.

Fugro West, Inc., 1998, East Bay injection/extraction groundwater pilot project well construction and performance testing Oro Loma Phase III injection/extraction demonstration well-Summary of operations report: Ventura, Calif., Fugro West, Inc., [variously paged].

Fugro West, Inc., 1999, East Bay injection/extraction pilot project, demonstration test operations report, [variously paged]. 
Galbraith, R.F., Roberts, R.G., Laslett, G.M., Yoshida, H., and Olley, J.M., 1999, Optical dating of single and multiple grains of quartz from Jinmium rock shelter, Northern Australia: Part I, Experimental design and statistical models: Archaeometry, v. 41, no. 2, p. 339-364, http://dx.doi.org/10.1111/j.1475-4754.1999.tb00987.x.

Galloway, D.L., Jones, D.R., and Ingebritsen, S.E., 1999, Land subsidence in the United States: U.S. Geological Survey Circular 1182, 175 p., http://pubs.er.usgs.gov/publication/cir1182.

Garbarino, J.R., Kanagy, L.K., and Cree, M.E., 2006, Determination of elements in natural-water, biota, sediment, and soil samples using collision/reaction cell inductively coupled plasma-mass spectrometry: U.S. Geological Survey Techniques and Methods, book 5, sec. B, chap. 1, 87 p., http://pubs.er.usgs.gov/publication/tm5B1.

Gasse, F., 1986, East African diatoms: Taxonomy, ecological distribution: Bibliotheca Diatomologica, v. 11, 201 p.

Graymer, R.W., 2000, Geologic map and map database of the Oakland metropolitan area, Alameda, Contra Costa, and San Francisco Counties, California: U.S. Geological Survey, Misc. Field Studies Map MF-2342, 1 sheet, scale 1:50,000, http://pubs.usgs.gov/mf/2000/2342.

Halford, K.J., and Kuniansky, E.L., 2002, Documentation of spreadsheets for the analysis of aquifer-test and slug-test data: U.S. Geological Survey Open-File Report 2002-197, 51 p., http://pubs.er.usgs.gov/publication/ofr02197.

Hille, D., 1980, Environmental soil physics: San Diego, California, Academic Press, 413 p.

Howard, A.D., 1979, Geologic history of middle California: California Natural History Guides, v. 43, 113 p.

Izbicki, J.A., Borchers, J.W., Leighton, D.A., Kulongoski, Justin, Fields, Latoya, Galloway, D.L., and Michel, R.L., 2003, Hydrogeology and geochemistry of aquifers underlying the San Lorenzo and San Leandro areas of the East Bay Plain, Alameda County, California: U.S. Geological Survey Water-Resources Investigations Report 2002-4259, 71 p., http://pubs.er.usgs.gov/ publication/wri024259.

Jennings, A.E., and Nelson, A.R., 1992, Foraminiferal assemblage zones in Oregon tidal marshesRelation to marsh floral zones and sea level: Journal of Foraminiferal Research, v. 22, no. 1, p. 13-29, http://dx.doi.org/10.2113/gsjfr.22.1.13.

Kendall, C., and McDonnell, J.J., eds., 1998, Isotope tracers in catchment hydrology: Amsterdam, Elsevier Science, 839 p.
Koltermann, C.E., and Gorelick, S.M., 1992, Paleoclimatic signature in terrestrial flood deposits: Science, v. 256, no. 5065, p. 1775-1782, http://dx.doi.org/10.1126/science.256.5065.1775.

Koterba, M.T., Wilde, F.D., and Lapham, W.W., 1995, Groundwater data-collection protocols and procedures for the National Water-Quality Assessment Program: Collection and documentation of water-quality samples and related data: U.S. Geological Survey Open-File Report 95-399, 114 p., http://pubs.er.usgs.gov/publication/ofr95399.

Krammer, Kurt, 1997a, Die cymbelloiden Diatomeen. Eine Monographie der weltweit bekannten Taxa, Teil 1, Allgemeines und Encyonema part: Stuttgart, Germany, J. Cramer, Bibliotheca Diatomologica Band 36, 382 p.

Krammer, Kurt, 1997b, Die cymbelloiden Diatomeen. Eine Monographie der weltweit bekannten Taxa, Teil 2, Encyonema part, Encyonopsis und Cymbellopsis: Stuttgart, Germany, J. Cramer, Bibliotheca Diatomologica Band 37, $469 \mathrm{p}$.

Krammer, Kurt, 2000, The genus Pinnularia, v. 1 of Lange-Bertalot, Horst, ed., Diatoms of Europe: Diatoms of the European inland waters and comparable habitats: Germany, A.R.G. Ganter Verlag K.G., 703 p.

Krammer, Kurt, 2002, Cymbella, v. 3 of Lange-Bertalot, Horst, ed., Diatoms of Europe: Diatoms of the European inland waters and comparable habitats: Germany, A.R.G. Ganter Verlag K.G., 514 p.

Krammer, Kurt and Lange-Bertalot, Horst, 1986, Bacillariophyceae, 1, Teil: Naviculaceae, in Ettl, H., Gerloff, J., Heynig, H., and Mollenhauer, D., eds., Süsswasser flora von Mitteleuropa, Band 2/1: New York, Gustav Fischer Verlag, 876 p.

Krammer, Kurt and Lange-Bertalot, Horst, 1988, Bacillariophyceae, 2, Teil: Bacillariaceae, Epithemiaceae, Surirellaceae, in Ettl, H., Gerloff, J., Heynig, H., and Mollenhauer, D., eds., Süsswasserflora von Mitteleuropa, Band 2/2: Jena, Germany, VEB Gustav Fischer Verlag, $596 \mathrm{p}$.

Krammer, Kurt and Lange-Bertalot, Horst, 1991a, Bacillariophyceae, 3, Teil: Centrales, Fragilariaceae, Eunotiaceae, in Ettl, H., Gerloff, J., Heynig, H., and Mollenhauer, D., eds., Süsswasserflora von Mitteleuropa, Band 2/3: Stuttgart, Germany, Gustav Fischer Verlag, 576 p.

Krammer, Kurt and Lange-Bertalot, Horst, 1991b, Bacillariophyceae, 4, Teil: Achnanthaceae, Kritische Ergänzungen zu Navicula (Lineolatae) und Gomphonema, Gesamtliteraturverzeichnis Teil 1-4, in Ettl, H., Gärtner, G., Gerloff, J., Heynig, H., and Mollenhauer, D., eds., Süsswasserflora von Mitteleuropa, Band 2/4: Stuttgart, Germany, Gustav Fischer Verlag, 437 p. 
Lambe, W.T. and Whitman, R.V., 1969, Soil mechanics (3d ed.), John Wiley and Sons, 553 p.

Lane. E.W., 1947, Report on the subcommittee on sediment terminology: Eos Transactions, American Geophysical Union, v. 28, no. 6, p. 936-938, http://onlinelibrary.wiley. com/doi/10.1029/TR028i006p00936/abstract.

Lange-Bertalot, Horst, 2001, Diatoms of Europe . Diatoms of the European inland waters and comparable habitats, v. 2, Navicula sensu stricto, 10 Genera Separated from Navicula sensu lato: Frustulia: Ruggell, Liechenstein, A.R.G. Gantner Verlag K.G., 526 p.

Lange-Bertalot, Horst, and Krammer, Kurt, 1987, Bacillariaceae, Epithemiaceae, Surirellaceae: Bibliotheca Diatomologica v. 15: Stuttgart, Germany, J. Cramer, 289 p.

Lange-Bertalot, Horst, and Krammer, Kurt, 1989, Achnanthes eine Monographie der Gattungen. Bibliotheca Diatomologica v. 18: Stuttgart, Germany, J. Cramer, 393 p.

Lepper, K., 2001, Development of an objective dose distribution analysis method for luminescence dating and pilot studies for planetary applications: Stillwater, Okla., Oklahoma State University, Ph.D. dissertation, 288 p.

Lepper, K., and McKeever, S.W.S., 2002, An objective methodology for dose distribution analysis: Radiation Protection Dosimetry, v. 101, no. 1-4, p. 349-352.

Locke, J.L., 1971, Sedimentation and foraminiferal aspects of the recent sediments of San Pablo Bay: San Jose, Calif., San Jose State College, M.S. thesis, 100 p.

Lowe, R.L., 1974, Environmental requirements and pollution tolerance of freshwater diatoms: U.S. Environmental Protection Agency Report EPA-670/4-74-005, National Environmental Research Center, Cincinnati, Ohio, 334 p.

Manheim, F.T., Brooks, E.G., and Winters, W.J., 1994, Description of a hydraulic sediment squeezer: U.S. Geological Survey Open-File Report 94-584, 39 p., http://pubs.er.usgs.gov/publication/ofr 94584 .

Marlow, M.S., Jachens, R.C., Hart, P.e., Carlson, P.R., Anima, R.J., and Childs, J.R., 1999, Development of San Leandro synform and neotectonics of the San Francisco Bay block, California: Marine and Petroleum Geology, v. 16, no. 5, p. 431-442, http://dx.doi.org/10.1016/S0264-8172(99)00002-1.

Maslonkowski, D. P., 1984, Groundwater in the San Leandro and San Lorenzo alluvial cones of the East Bay plain of Alameda County: Alameda County Flood Control and Water Conservation District, $31 \mathrm{p}$.
Maslonkowski, D.P., 1988, Hydrogeology of the San Leandro and San Lorenzo alluvial cones of the bay plain groundwater basin, Alameda County, California: San Jose, Calif., San Jose State College, M.S. thesis, 143 p.

McCormick, J.M., Severin, K.P., and Lipps, J.H., 1994, Summer and winter distribution of foraminifera in Tomales Bay, northern California: Cushman Foundation for Foraminiferal Research Special Publication, v. 32, p. 69-101.

McGann, M., 2007, Foraminiferida in Carlton, J.T., ed., The Light and Smith Manual (4th ed.): Intertidal invertebrates from central California to Oregon: Berkeley and Los Angeles, Calif., University of California Press, p. 46-69.

McGann, M., Sloan, Doris, and Wan, Elmira, 2002, Biostratigraphy beneath central San Francisco Bay along the San Francisco-Oakland Bay Bridge transect, in Parsons, Tom, eds., Crustal Structure of the Coastal and Marine San Francisco Bay Region, California: U.S. Geological Survey Professional Paper 1658, p. 11-28, http://pubs.er.usgs.gov/publication/pp1658.

Means, K.D., 1965, Sediments and foraminifera of Richardson Bay, California: Los Angeles, Calif., University of Southern California, M.A. thesis, $80 \mathrm{p}$.

Michel, R.M., 1989, Tritium deposition in the continental United States, 1953-83: U.S. Geological Survey WaterResources Investigations Report 89-4072, 46 p., http://pubs.er.usgs.gov/publication/wri894072.

Muir, K.S., 1997, Ground water quality in the East Bay Plain: Hayward, Calif., Alameda County Department of Public Works, 7 p.

Murray, A.S., Olley, J.M., and Caitcheon, G.G., 1995, Measurement of equivalent doses in quartz from contemporary water-lain sediments using optically stimulated luminescence: Quaternary Science Reviews, v. 14, no. 4, p. 365-371, http://dx.doi.org/10.1016/0277-3791(95)00030-5.

Murray, J.W., 1973, Distribution and ecology of living benthic foraminiferids: NewYork, Crane, Russak and Company, $274 \mathrm{p}$.

Nesse, W.D., 2000, Introduction to mineralogy: New York, Oxford University Press Inc.

Nightingale, H.I., and Bianchi, W.C., 1977, Groundwater turbidity resulting from artificial recharge: Groundwater, v. 15, no. 2, p. 146-152, http://dx.doi. org/10.1111/j.1745-6584.1977.tb03159.x. 
Olley, Jon, Caitcheon, Gary, and Murray, Andrew, 1998, The distribution of apparent dose as determined by optically stimulated luminescence in small aliquots of fluvial quartz: Implications for dating young sediments: Quaternary Science Review, v. 17, no. 11, p. 1033-1040, http://dx.doi.org/10.1016/S0277-3791(97)00090-5.

Parker, F.L., and Athearn, W.D., 1959, Ecology of marsh foraminifera in Poponesset Bay, Massachusetts: Journal of Paleontology, v. 33, no. 2, p. 333-343, http://www.jstor.org/stable/1300762.

Pavelko, M.T., 2000, Ground-water and aquifer-systemcompaction data from the Lorenzi Site, Las Vegas, Nevada, 1994-99: U.S. Geological Survey Open-File Report 2000362, 26 p., http://pubs.er.usgs.gov/publication/ofr00362.

Phleger, F.B., 1967, Marsh foraminiferal patterns, Pacific Coast of North America: Ann. Institute Biolologie Universita National Auton. Mexico 38, Series Cienco Del Mar y Limnolologie, v. 1, p. 11-38.

Phleger, F.B., 1970, Foraminiferal populations and marine marsh processes: Limnology and Oceanography, v. 15 , no. 4, p. 522-534, http://aslo.org/lo/toc/vol_15/ issue_4/0522.pdf.

Prescott, J.R., and Hutton, J.T., 1994, Cosmic ray contributions to dose rates for luminescence and ESR dating: Large depths and long-term time variations: Radiation Measurements, v. 23, no. 2-3, p. 497-500, http://dx.doi.org/10.1016/1350-4487(94)90086-8.

Puls, R.W., and Powell, R.M., 1992, Acquisition of representative ground water quality samples for metals: Groundwater Monitoring \& Remediation, v. 12 , no. 3 , p. $167-176$, http://dx.doi.org/10.1111/j.1745-6592.1992.tb00057.x.

Quinterno, P.J., 1968, Distribution of recent foraminifera in central and south San Francisco Bay: San Jose, Calif., San Jose State College, M.S. thesis, 83 p.

Ray, M.C., Kulongoski, J.T., and Belitz, Kenneth, 2009, Ground-water quality data in the San Francisco Bay study unit, 2007: Results from the California GAMA Program: U.S. Geological Survey Data Series 396, 93 p., http://pubs.er.usgs.gov/publication/ds396.

Riley, F.S., 1984, Developments of borehole extensometry in Johnson, A.I., Carbognin, L., and Ubertini, L., eds., Land subsidence: International Association of Hydrological Sciences Publication no. 151, p. 169-186.

Rogers, J.D., and Figuers, S.H., 1991, Engineering geologic site characterization of the greater Oakland-Alameda area, Alameda and San Francisco Counties, California: Pleasant Hill, Calif,. Rogers/Pacific, Inc., 59 p.
Rosenberry, D.O., 1990, Effect of sensor error on interpretation of long-term water-level data: Groundwater, v. 28, no. 6, p. 927-936, http://dx.doi.org/ 10.1111/j.1745-6584.1990.tb01729.x.

Ross, B.E., 1977, The Pleistocene history of San Francisco Bay along the southern crossing: San Jose, Calif., San Jose State College, M.S. thesis, 121 p.

Round, F.E., and Bukhtiyarova, Ludmila, 1996, Four new genera based on Achnanthes (Achnanthidium) together with a re-definition of Achnanthidium: Diatom Research, v. 11, no. 2, p. 345-361, http://dx.doi.org/10.1080/0269249X.1996.9705389.

San Francisco Bay Regional Water Quality Control Board, 1999, East Bay Plain groundwater basin beneficial use evaluation report: Oakland, Calif. [variously paged].

Schmertmann, J.H., 1954, The undisturbed consolidation behavior of clay: Transactions, American Society of Civil Engineers, v. 120, no. 2775, p. 1201-1227.

Schrader, H.J., and Gersonde, R., 1978, Diatoms and silicoflagellates, in Zachariasse, W.J., and others (eds.), Micropaleontological counting methods and techniques: An exercise of an eight metres section of the lower Pliocene of Capo Rossello, Sicily: Utrecht Micropaleontological Bulletin 17, p. 129-176.

Scott, D.B., and Medioli, F.S., 1980, Living vs. total foraminiferal populations: Their relative usefulness in paleoecology: Journal of Paleontology, v. 54, no. 4, p. 814-831.

Scott, D.B., Mudie, P.J., and Bradshaw, J.S., 1976, Benthonic foraminifera of three southern Californian lagoons; Ecology and recent stratigraphy: Journal of Foraminiferal Research, v. 6, no. 1, p. 59-75, http://dx.doi.org/10.2113/gsjfr.6.1.59.

Scott, D.B., Williamson, M.A., and Duffett, T.E., 1981, Marsh foraminifera of Prince Edward IslandTheir recent distribution and application for former sea level studies: Maritime Sediments and Maritime Geology, v. 17, no. 3, p. 98-129, http://journals.hil.unb.ca/index.php/ag/article/view/1380.

Sedlock, R.L., 1995, Tectonic framework, origin, and evolution of the San Francisco Bay region, in Sangines, E.M., Andersen, D.W., and Buising, A.V., eds., Recent geologic studies in the San Franciso Bay area: Pacific Section of the Society of Economic Paleontologists and Mineralogists, Book 76, p. 1-17.

Slater, R.A., 1965, Sedimentary environments in Suisun Bay, California: Los Angeles, Calif., University of Southern California, M.A. thesis, $104 \mathrm{p}$. 
Sloan, Doris, 1992, The Yerba Buena mud: Record of the lastinterglacial predecessor of San Francisco Bay, California: Geological Society of America Bulletin, v. 104, no. 6, p. 716-727.

Sneed, Michelle, 2001, Hydraulic and mechanical properties affecting ground-water flow and aquifersystem compaction, San Joaquin Valley, California: U.S. Geological Survey Open File 2001-35, 26 p., http://pubs.er.usgs.gov/publication/ofr0135.

Sneed, Michelle, and Galloway, D.L., 2000, Aquifer-system compaction and land subsidence: Measurements, analyses, and simulations - The Holly site, Edwards Air Force Base, Antelope Valley, California: U.S. Geological Survey WaterResources Investigations Report 2000-4015, 65 p., http://pubs.er.usgs.gov/publication/wri20004015.

Sneed, Michelle, Borchers, J.W., Kayen, R.E., Carkin, B.A., Ellett, K.M., Wheeler, G.A., and Brocher, T.M, 2007, Hydromechanical response characterization by integration of geophysical and hydrological data, San Lorenzo, California, Eos, Transactions, American Geophysical Union, v. 88, no. 52, Fall Meeting Supplement, Abstract H23A1007.

Strausberg, S.I., 1983, Turbidity interferes with accuracy in heavy metal concentrations: Industrial Wastes, v. 29, no. 2, p. 16-21.
Trask, P.D., and Rolston, J.W., 1951, Engineering geology of San Francisco Bay, California: Geological Society of America Bulletin, v. 62, no. 9, p. 1079-1110, http://dx.doi. org/10.1130/0016-7606(1951)62[1079:EGOSFB]2.0.CO;2.

U.S. Geological Survey, 2012, Earthquake Hazards Program, Soil type and shaking hazard in the San Francisco Bay area, accessed December 11, 2012, http://earthquake.usgs.gov/regional/nca/soiltype/.

U.S. Geological Survey, [various dates], National field manual for the collection of water-quality data: U.S. Geoloigical Survey Techniques of WaterResources Investigations, book 9, chap. A1-A9, http://water.usgs.gov/owq/FieldManual/.

Waters Corporation, 1992, Method A-103, Anion analysis using IC-Pak a HR column with borate/gluconate eluent: Waters Innovative Methods, 12 p.

Wilde, F.D., Radtke, D.B., Gibbs, J., and Iwatsubo, R.T., 2006, Collection of water samples: U.S. Geological Survey Techniques of Water-Resources Investigations, book 9, chap. A4, accessed June 28, 2007, http://pubs.water.usgs.gov/twri9A4/.

Wolf, R.E., Introduction to ICP-MS, U.S. Geological Survey, March 2005, accessed February 24, 2009, http://minerals.cr.usgs.gov/icpms/intro.html. 
Prepared by the Sacramento Publishing Service Center.

For more information concerning this report, contact:

Director

U.S. Geological Survey

California Water Science Center

6000 J Street, Placer Hall

Sacramento, CA 95829

or visit our Web site at:

http://ca.water.usgs.gov 


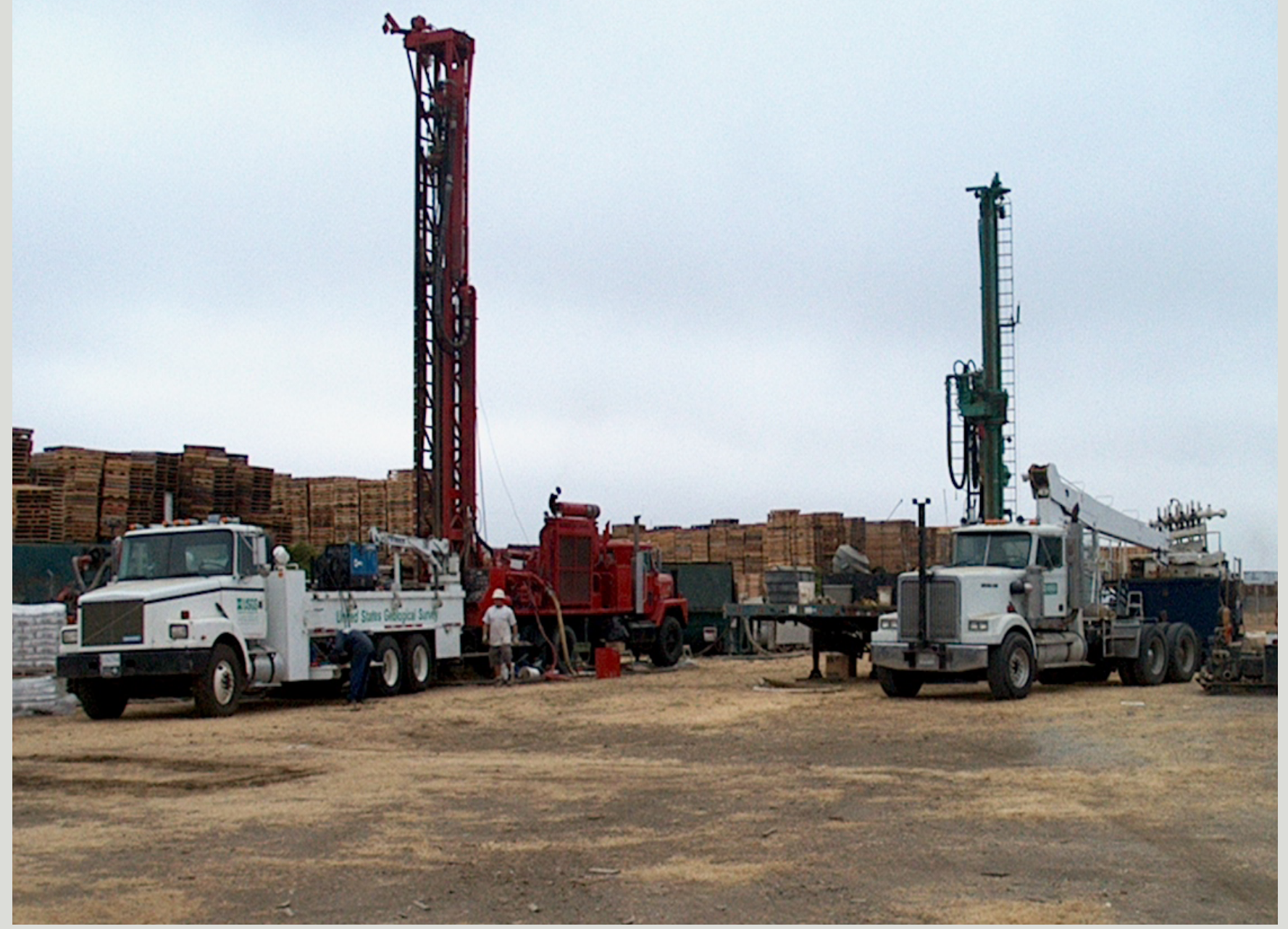

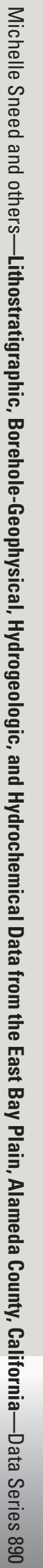

